\title{
CARACTERÍSTICAS DAS SUPERFÍCIES FOLIARES DE ALGUMAS PLANTAS DANINHAS E ESTUDO DA ABSORÇÃO E TRANSLOCAÇÃO DE 2,4-D EM Memora peregrina (Miers) Sandwith
}

\author{
CRISTIANE GONÇALVES DE MENDONÇA
}

Tese apresentada à Escola Superior de Agricultura “Luiz de Queiroz”, Universidade de São Paulo, para obtenção do título de Doutor em Agronomia, Área de Concentração: Fitotecnia.

\author{
PIRACICABA \\ Estado de São Paulo - Brasil \\ Junho - 2004
}




\title{
CARACTERÍSTICAS DAS SUPERFÍCIES FOLIARES DE ALGUMAS PLANTAS DANINHAS E ESTUDO DA ABSORÇÃO E TRANSLOCAÇÃO DE 2,4-D EM Memora peregrina (Miers) Sandwith
}

\author{
CRISTIANE GONÇALVES DE MENDONÇA \\ Engenheira Agrônoma
}

Orientador: Prof. Titular RICARDO VICTORIA FILHO

Tese apresentada à Escola Superior de Agricultura “Luiz de Queiroz”, Universidade de São Paulo, para obtenção do título de Doutor em Agronomia, Área de Concentração: Fitotecnia.

\author{
PIRACICABA \\ Estado de São Paulo - Brasil \\ Junho - 2004
}




\section{Dados Internacionais de Catalogação na Publicação (CIP)}

DIVISÃO DE BIBLIOTECA E DOCUMENTAÇÃO - ESALQ/USP

Mendonça, Cristiane Gonçalves de

Características das superfícies foliares de algumas plantas daninhas e estudo da absorção e translocação de 2,4-D em Memora peregrina (Miers) Sandwith / Cristiane Gonçalves de Mendonça. - Piracicaba, 2004.

95 p. : il.

Tese (doutorado) - Escola Superior de Agricultura Luiz de Queiroz, 2004.

Bibliografia.

1. Anatomia vegetal 2. Folhas (Planta) 3. Herbicidas - Absorção - Translocação 4. Plantas daninhas I.Título

CDD 632.58 
“O Senhor é meu pastor, nada me faltará.

Em verdes prados ele me faz repousar. Conduz-me junto às águas refrescantes,

Restaura as forças de minha alma. Pelos caminhos retos ele me leva, por amor de seu nome.

Ainda que eu atravesse o vale escuro, nada temerei, pois estais comigo. Vosso bordão e vosso báculo são o meu amparo.

Preparais para mim a mesa à vista de meus inimigos. Derramais o perfume sobre minha cabeça, e transborda minha taça.

A vossa bondade e misericórdia hão de seguir-me por todos os dias da minha vida. E habitarei na casa do Senhor por longos dias.”

Salmo 22 
Dedico à minha família:

Jair

Maria Helena

Cristina

\section{Juliana}

Pelo amor, amizade e sentido de vida. 


\section{AGRADECIMENTOS}

- Ao Prof. Titular Ricardo Victoria Filho pela orientação, amizade, compreensão nos momentos difíceis e confiança depositada na minha capacidade para a realização desta tese. Neste período, pude conhecer o significado de “Orientador-pai”, pois não foram somente conhecimentos técnicos que adquiri, mas também conheci o respeito pelo ser humano, sabedoria esta não adquirida em livros, mas transmitida apenas por pessoas humanitárias.

- À minha irmã Cristina Gonçalves de Mendonça pelo amor, amizade, a imensa ajuda e incentivo para a execução desta tese e pelas valiosas sugestões em todos os momentos de minha vida.

- Ao Prof. Pedro Jacob Christoffoleti pela amizade, confiança depositada no meu trabalho e pelos conhecimentos adquiridos neste curso de pós-graduação.

- Ao Prof. Valdemar Luis Tornisielo pela amizade e dedicação na execução do estudo de absorção e translocação de herbicida.

- Ao Prof. Elliot Watanabe Kitajima do Núcleo de Apoio à Pesquisa/ Microscopia Eletrônica Aplicada à Pesquisa Agropecuária da Esalq/USP.

- Ao Pesquisador da Embrapa de Gado de Corte Sr. Saladino Gonçalves Nunes.

- Aos amigos Luciane Ap. Lopes Toledo, Adriana M. M. Pires, Cristina M. Veiga, André Luiz de S. Lacerda e Victor M. Marcon, meus fiéis companheiros em Piracicaba.

- A João Carlos de Angelo pelo apoio durante a realização desta tese.

- Aos funcionários e professores do Departamento de Horticultura, e em especial às secretárias Célia, Beth e D. Helena e aos funcionários Oni, Luiz Ferrari e Aparecido.

- Aos novos amigos da UEMS-Cassilândia: Stela, Luciana, Wilson, Guilherme, Adriana, Anamari e Edemir. E a compreensão dos alunos do $2^{0}$ e $3^{\underline{0}}$ ano do curso de Agronomia. 
- À Universidade Estadual de Mato Grosso do Sul - Unidade de Cassilândia (Curso de Agronomia) pelo período de capacitação concedido para finalização desta tese.

- A Capes e Fapesp pela concessão da bolsa de doutorado.

- A todos que, direta ou indiretamente, contribuíram para a execução desta tese. 


\section{SUMÁRIO}

\section{Página}

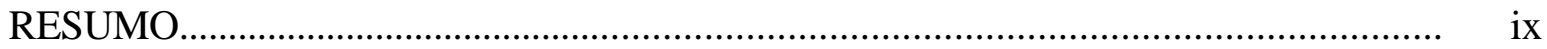

SUMMARY

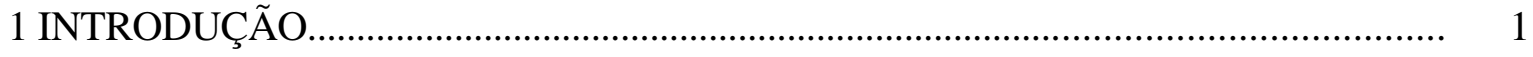

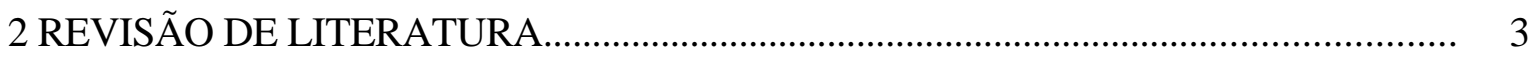

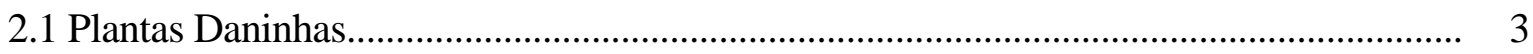

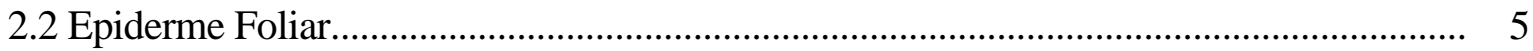

2.3 Aplicação $\quad$ e $\quad$ Deposição $\quad$ dos $\quad$ Herbicidas $\quad$ no 9

Alvo.

2.4 Absorção e Translocação de Herbicidas.................................................................. 10

3 CARACTERÍSTICAS DAS SUPERFÍCIES FOLIARES DE PLANTAS DANINHAS. I

- APOCYNACEAE: Peschiera fuchsiaefolia e ASTERACEAE: Vernonia polyanthes e

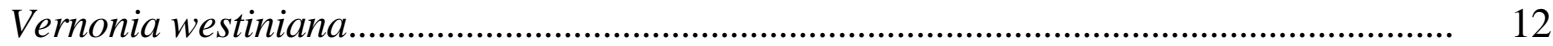

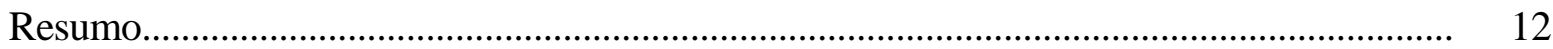

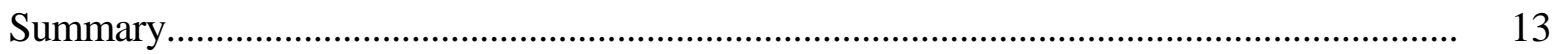

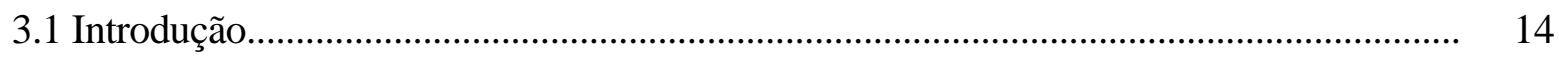

3.2 Material e Métodos.................................................................................................................. 17

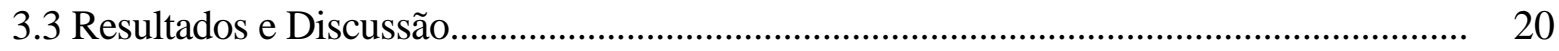

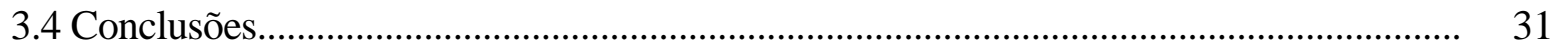

4 CARACTERÍSTICAS DAS SUPERFÍCIES FOLIARES DE PLANTAS DANINHAS.

II - BIGNONIACEAE: Memora peregrina e Tecoma stans e CONVOLVULACEAE:

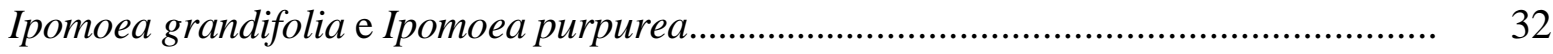

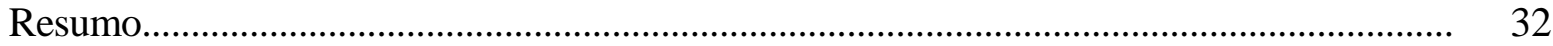




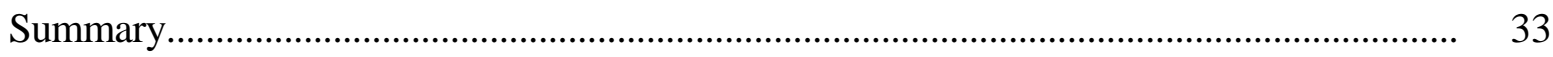

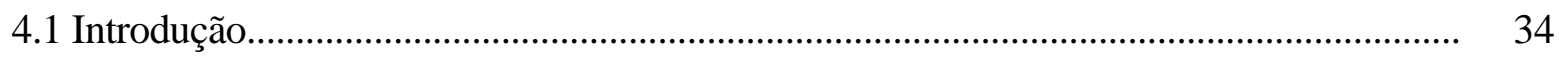

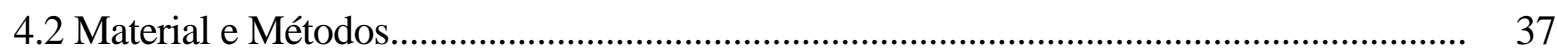

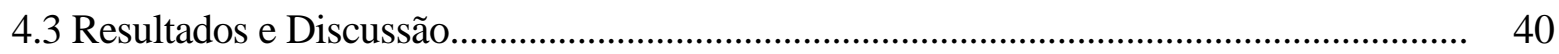

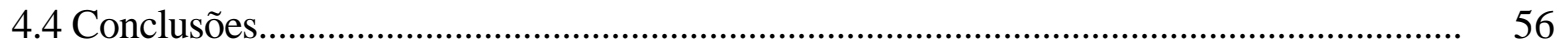

5 CARACTERÍSTICAS DAS SUPERFÍCIES FOLIARES DE PLANTAS DANINHAS.

III - EUPHORBIACEAE: Euphorbia heterophylla e MALVACEAE: Sida rhombifolia e

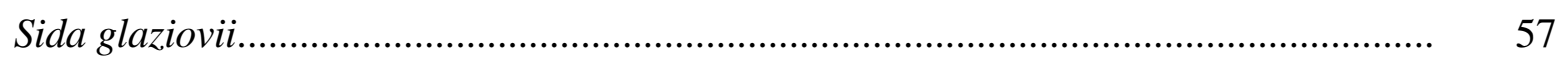

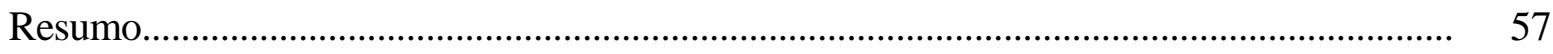

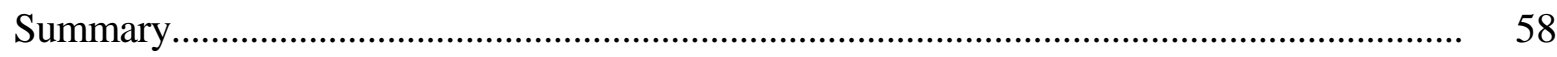

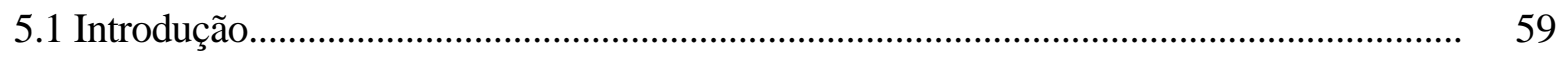

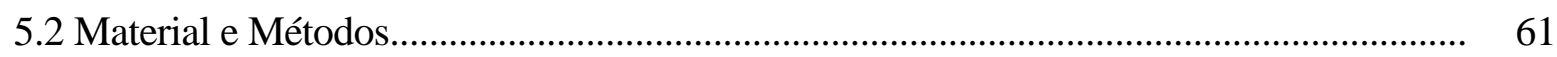

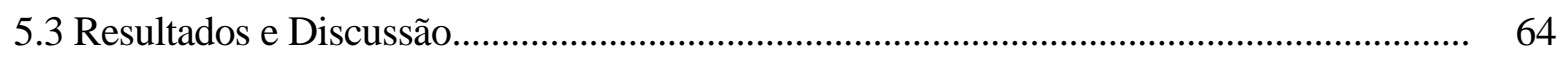

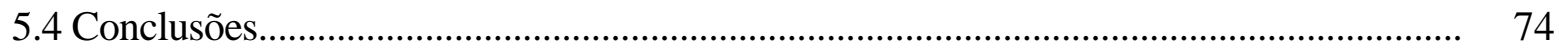

6 ESTUDO DA ABSORÇÃO E TRANSLOCAÇÃO DE 2,4-D EM PLANTAS DE

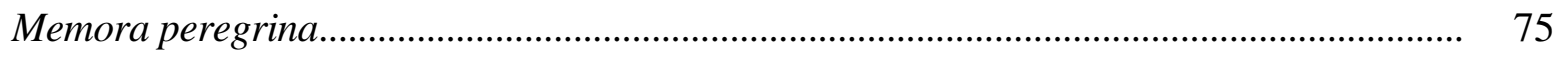

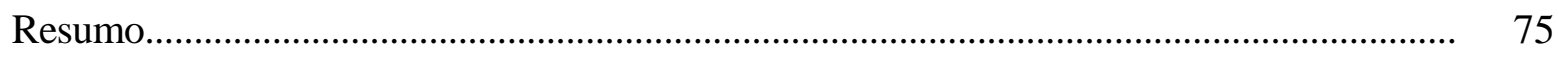

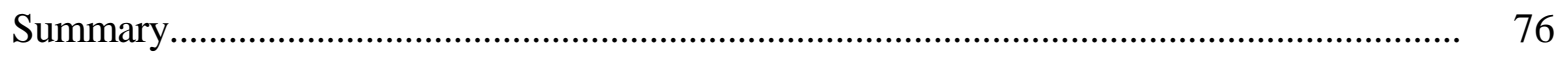

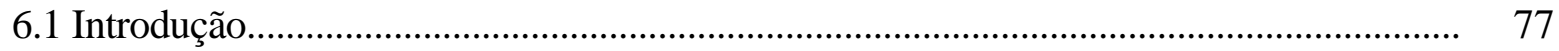

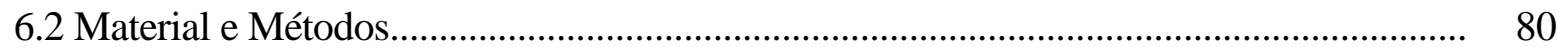

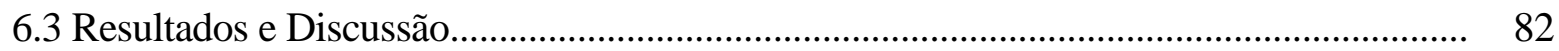

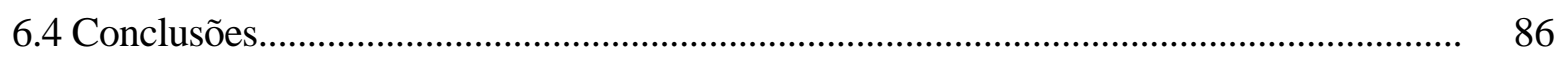

7 CONCLUSÕES GERAIS..................................................................................... 87

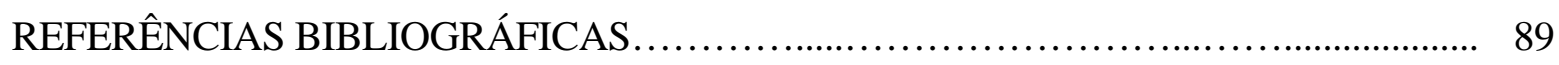




\title{
CARACTERÍSTICAS DAS SUPERFÍCIES FOLIARES DE ALGUMAS PLANTAS DANINHAS E ESTUDO DA ABSORÇÃO E TRANSLOCAÇÃO DE 2,4-D EM Memora peregrina (Miers) Sandwith
}

\author{
Autora: CRISTIANE GONÇALVES DE MENDONÇA \\ Orientador: Prof. Dr. RICARDO VICTORIA FILHO
}

\section{RESUMO}

O objetivo desta pesquisa foi avaliar a densidade estomática, a porcentagem de compostos polares e apolares das ceras epicuticulares e observar as características ultra-estruturais da cutícula foliar de Peschiera fuchsiaefolia (A. DC.) Miers, Vernonia polyanthes Less., Vernonia westiniana Less., Memora peregrina (Miers) Sandwith, Tecoma stans (L.) Juss. ex Kunth, Ipomoea grandifolia (Dammer) O’Donell, Ipomoea purpurea (L.) Roth., Euphorbia heterophylla L., Sida rhombifolia L. e Sida glaziovii K. Schum.. Outro objetivo foi avaliar a absorção e translocação do herbicida 2,4D radiomarcado em plantas de Memora peregrina. A densidade estomática foi determinada aderindo a epiderme foliar em lâmina de vidro. As ceras epicuticulares foram extraídas com clorofórmio e fracionadas em compostos apolar e polar usando uma coluna de sílica gel. A análise ultra-estrutural foi realizada por meio de Microscopia Eletrônica de Varredura. A absorção e a translocação do herbicida ${ }^{14} \mathrm{C}$ 2,4-D foram determinadas no 2,4-D sozinho (DMA 806 BR) e na mistura de 2,4-D e picloram (DMA 806 BR+Padron), nos intervalos de tempo de 1, 2, 4, 8, 24 e 48 horas após as aplicações. P. fuchsiaefolia apresentou densidade estomática de 11,8 e 209,4 estômatos $/ \mathrm{mm}^{2}$ de área foliar (adaxial e abaxial), tricomas curtos na superfície adaxial e $41,9 \mu \mathrm{g}$ de cera $/ \mathrm{cm}^{2}$ (88,8 \% de compostos polares). A densidade estomática em $V$. polyanthes foi 36,5 e 99,7 
estômatos $/ \mathrm{mm}^{2}$ e em $V$. westiniana 45,2 e 154,9 estômatos $/ \mathrm{mm}^{2}$. Em $V$. polyanthes encontrou-se $31,1 \mu \mathrm{g}$ de cera $/ \mathrm{cm}^{2}$ (15\% compostos apolares e $85 \%$ polares), enquanto a espécie $V$. westiniana apresentou 42,9 $\mu \mathrm{g}$ de cera/ $\mathrm{cm}^{2}$ (7,6\% apolares e 92,4\% de polares). A espécie $M$. peregrina apresentou 368,0 estômatos $/ \mathrm{mm}^{2}$ na superfície abaxial e estavam ausentes na adaxial, enquanto que $T$. stans apresentou 9,7 estômatos $/ \mathrm{mm}^{2}$ na adaxial e 78,2 na abaxial. A porcentagem de compostos polares foi 58,5\% em $M$. peregrina, com 22,8 $\mu$ g de cera/ $\mathrm{cm}^{2}$ e $T$. stans apresentou $16,8 \mu \mathrm{g} / \mathrm{cm}^{2}$, sendo $59,5 \%$ compostos polares. A densidade estomática de I. grandifolia foi 44,0 estômatos $/ \mathrm{mm}^{2}$ na adaxial e 156,0 na abaxial e na espécie $I$. purpurea foi 62,8 estômatos/ $/ \mathrm{mm}^{2}$ na adaxial e 131,2 na abaxial. As espécies do gênero Ipomoea apresentaram maiores quantidades de compostos polares, tricomas unicelulares e ceras epicuticulares em forma de estrias nas superfícies adaxiais. A densidade estomática de E. heterophylla foi 140,5 estômatos $/ \mathrm{mm}^{2}$ na superfície adaxial e 215,2 na abaxial, com depósito em forma de cristais e com 46,0 $\mu$ g de cera/ $\mathrm{cm}^{2}$ (48,9\% compostos apolares e 51,1\% polares). A densidade estomática de S. rhombifolia foi 101,1 estômatos $/ \mathrm{mm}^{2}$ (adaxial) e 212,6 (abaxial), e em S. glaziovii foi 118,6 e 187,3 estômatos $/ \mathrm{mm}^{2}$. As espécies S. rhombifolia e S. glaziovii apresentaram maiores porcentagens de compostos polares (75,9\% e 62,1\%, respectivamente). As porcentagens de absorção do ${ }^{14} \mathrm{C}$ 2,4-D uma hora após a aplicação foram 8,22\% e 9,63\%, para os tratamentos com 2,4-D e 2,4-D + picloram, respectivamente. E 48 horas após a aplicação, a absorção foi 23,81\% no tratamento 2,4D e 24,26\% com 2,4-D + picloram e deste total absorvido 98,44\% permaneceu na folha tratada no tratamento com o 2,4-D e 99,50\% quando se usou a mistura 2,4-D+picloram, caracterizando translocação muito pequena deste herbicida. 


\title{
FOLIAR SURFACES CHARACTERISTICS OF SOME WEEDS AND STUDY OF THE ABSORPTION AND TRANSLOCATION OF 2,4-D IN Memora peregrina (Miers) Sandwith
}

\author{
Author: CRISTIANE GONÇALVES DE MENDONÇA \\ Adviser: Prof. Dr. RICARDO VICTORIA FILHO
}

\section{SUMMARY}

The objective of this research was to evaluate the stomatal density, the percentage of polar and apolar compounds of the epicuticular waxes and to observe the ultra-structural characteristics of the foliar cuticle of Peschiera fuchsiaefolia (A. DC.) Miers, Vernonia polyanthes Less., Vernonia westiniana Less., Memora peregrina (Miers) Sandwith, Tecoma stans (L.) Juss. ex Kunth, Ipomoea grandifolia (Dammer) O’Donell, Ipomoea purpurea (L.) Roth., Euphorbia heterophylla L., Sida rhombifolia L. and Sida glaziovii K. Schum.. Other objective was to evaluate the absorption and translocation of the radiolabelled herbicide 2,4-D in plants of Memora peregrina. The stomatal density was determined by the impression of the foliar epidermis in sheet of glass. The epicuticular waxes were extracted with chloroform and they divided in apolar and polar compounds using a column of silica gel. The ultra-structural analysis was realized using the Scanning Electronic Microscopy. The absorption and translocation of the ${ }^{14} \mathrm{C}$ 2,4-D were evaluated using the 2,4-D alone (DMA $806 \mathrm{BR}$ ) or the mixture of 2,4-D plus picloram (DMA 806 BR+Padron), in different time after the applications (1, 2, 4, 8, 24 and 48 hours). P. fuchsiaefolia presented stomatal density of 11.8 and 209.4 stomatas $/ \mathrm{mm}^{2}$ of foliar area (adaxial and abaxial), short trichomes in the adaxial surface and $41.9 \mu \mathrm{g}$ of wax $/ \mathrm{cm}^{2}$ being $88.8 \%$ of polar compounds. The stomatal density in 
adaxial and abaxial surfaces of $V$. polyanthes was 36.5 and 99.7 stomatas $/ \mathrm{mm}^{2}$, respectively, and in $V$. westiniana was 45.2 and 154.9 stomatas $/ \mathrm{mm}^{2}$. In leaves of $V$. polyanthes were removed $31.1 \mu \mathrm{g}$ of wax $/ \mathrm{cm}^{2}$ (15.0\% apolar compounds and $85.0 \%$ polar compounds), whereas in the specie $V$. westiniana were extracted $42.9 \mu \mathrm{g}$ of wax $/ \mathrm{cm}^{2}$ (7.6\% apolar and $92.4 \%$ polar). The specie $M$. peregrina had 368.0 stomatas $/ \mathrm{mm}^{2}$ in the abaxial surface and in to adaxial they were absent, in plants of $T$. stans were achieved 9.7 stomatas $/ \mathrm{mm}^{2}$ in the adaxial surface and 78.2 in the abaxial. The percentage of polar compounds was $58.5 \%$ in M. peregrina, with $22,8 \mu \mathrm{g}$ of wax $/ \mathrm{cm}^{2}$ and the plants of $T$. stans presented $16.8 \mu \mathrm{g} / \mathrm{cm}^{2}$, being $59.5 \%$ of polar compounds. The stomatal density of I. grandifolia was 44.0 stomatas $/ \mathrm{mm}^{2}$ in the adaxial and 156.0 in the abaxial and in the specie I. purpurea was 62.8 stomatas $/ \mathrm{mm}^{2}$ and 131.2 in the abaxial. The species of the Ipomoea genus had great amounts of polar compounds, unicellular trichomes and epicuticular waxes in the form of ridge in the adaxial surfaces. The stomatal density of E. heterophylla was 140.5 stomatas $/ \mathrm{mm}^{2}$ in at adaxial surface and 215.2 in the abaxial, with deposit in the form of crystals and with $46.0 \mu \mathrm{g}$ of wax $/ \mathrm{cm}^{2}$ (48.9\% apolar compounds and 51.1\% polar). The stomatal density of S. rhombifolia was 101.1 stomatas $/ \mathrm{mm}^{2}$ (adaxial) and 212.6 (abaxial) and in S. glaziovii the stomatal density was 118.6 and 187.3 stomatas $/ \mathrm{mm}^{2}$. The species S. rhombifolia and S. glaziovii presented great percentages of polar compounds, $75.9 \%$ and $62.1 \%$, respectively. The percentage of absorption of the ${ }^{14} \mathrm{C}$ 2,4-D one hour after the application were $8.22 \%$ and 9.63\%, for the treatments with 2,4-D and 2,4-D + picloram, respectively. The absorption 48 hours after the application was $23.81 \%$ in the treatment with 2,4-D and 24.26\% with 2,4-D+picloram. In this same interval of time, $98.44 \%$ absorbed total stayed in the treated leaf in the treatment with 2,4-D and 99.50\% with mixture 2,4-D+picloram, then the translocation of this herbicide was considered insignificant. 


\section{INTRODUÇÃO}

As plantas daninhas competem com as plantas cultivadas por água, luz e nutrientes, e em certas ocasiões são tóxicas aos animais, como no caso de algumas invasoras de pastagens. Dentre as limitações para o desenvolvimento de plantas cultivadas estão as plantas daninhas, interferindo tanto em culturas anuais e perenes como em pastagens.

Em aplicações de herbicidas em pós-emergência, as folhas representam a principal rota de entrada dos herbicidas nas plantas e a eficácia nesta absorção poderá definir o controle. Nas folhas localizam-se muitas estruturas funcionais, como ceras (evitam a desidratação da planta e protegem contra os danos mecânicos) e estômatos (executam trocas gasosas), além da presença de tricomas, apêndices, tricomas glandulares, entre outras. A presença ou ausência dessas estruturas funcionais nas folhas influenciará a entrada do herbicida através da cutícula. O conhecimento dessas estruturas funcionais elucida as possíveis interações entre os herbicidas e as superfícies foliares das plantas daninhas, durante o processo de absorção. Após a absorção do herbicida pela planta, este poderá ser translocado ou não, fato este definido principalmente pelas características químicas da molécula. Desta maneira, este herbicida chegará ao seu sítio de ação, levando a morte da planta daninha.

As superfícies foliares de plantas daninhas são os alvos que o herbicida veiculado na calda de pulverização deve atingir. O conhecimento das características das superfícies foliares determina a utilização mais adequada do herbicida e conseqüentemente sua eficácia no controle.

Contudo, as interações desde o momento da aplicação da calda até a ação do herbicida dentro da planta envolvem processos complexos, como: a formulação do 
herbicida comercial, as condições ambientais no momento da aplicação, o volume de calda utilizado, as características anatômicas da superfície foliar, as características físicoquímicas da molécula do herbicida, a anatomia interna da planta, o movimento de fotossintetizados (fonte-dreno), os aspectos fisiológicos da planta daninha, etc. Por envolver grandes áreas de conhecimento, como a Tecnologia de Aplicação de Defensivos Agrícolas, a Fitotecnia, a Fisiologia Vegetal e a Bioquímica, as pesquisas científicas conduzidas na área da Ciência das Plantas Daninhas geralmente envolvem diversas áreas do conhecimento, porém cabe ao pesquisador englobar os resultados obtidos em pesquisas das diversas áreas para compreender os diferentes processos e aplicá-los à agricultura brasileira. Portanto esta pesquisa contribuirá com uma parcela dos conhecimentos necessários para o entendimento dos complexos processos encontrados na área da Ciência das Plantas Daninhas.

Os objetivos desta pesquisa foram determinar a densidade estomática, caracterizar as ceras epicuticulares quanto a porcentagem de compostos polares e apolares, a quantidade de cera por área foliar e estudar as características ultra-estruturais de superfícies foliares, por meio de microscopia eletrônica de varredura, das seguintes plantas daninhas: Peschiera fuchsiaefolia (A. DC.) Miers, Vernonia polyanthes Less., Vernonia westiniana Less., Memora peregrina (Miers) Sandwith, Tecoma stans (L.) Juss. ex Kunth, Ipomoea grandifolia (Dammer) O’Donell, Ipomoea purpurea (L.) Roth., Euphorbia heterophylla L., Sida rhombifolia L. e Sida glaziovii K. Schum. Outro objetivo deste estudo foi determinar a absorção e translocação do herbicida 2,4-D radiomarcado em plantas de $M$. peregrina. 


\section{REVISÃO DE LITERATURA}

\subsection{Plantas Daninhas}

As plantas daninhas são plantas que ocorrem em locais não desejados pelo homem. Elas ocorrem em culturas perenes e anuais, como em pastagens, ou seja, em locais utilizados pelo homem para a produção agropecuária no sustento da humanidade. As plantas daninhas competem com as plantas cultivadas por luz, água e nutrientes, além de causar interferências como a alelopatia e algumas delas serem tóxicas aos animais. Na agricultura, as plantas daninhas reduzem a produção de alimentos e na pecuária as plantas daninhas interferem com as forrageiras reduzindo a capacidade de lotação das pastagens, além de algumas delas causarem ferimentos aos animais e serem plantas tóxicas (Victoria Filho, 1986).

Segundo Lorenzi (2000), Kissmann \& Groth (2000) e Kissmann \& Groth (1999) as plantas daninhas estudadas apresentam as seguintes características:

Peschiera fuchsiaefolia (A. DC.) Miers é uma planta perene, ereta, muito lactescente, arbustiva ou arbórea, de 2-4 m de altura e nativa do Brasil. Propaga-se por sementes e por um extenso sistema de rizomas subterrâneos. É uma séria infestante de pastagens em quase todo o país, com concentração na região Sudeste e Sudoeste. Possui grande habilidade reprodutiva e alta rusticidade (pouco exigente na fertilidade do solo).

Vernonia polyanthes Less. é uma planta perene, arbustiva ou arbórera, pouco ramificada, com caules pubescentes e de coloração acinzentada, com 1-3 m de altura e nativa do território brasileiro. Propaga-se por sementes, grande capacidade de recuperação quando a parte aérea é cortada ou destruída por geadas. É uma das plantas daninhas mais frequentes e mais temidas das nossas pastagens, ocorrendo nas regiões 
Sudeste e Centro-Oeste do país. Geralmente ocorre em grandes infestações que chegam a anular a capacidade de lotação.

Vernonia westiniana Less. é uma planta perene, arbustiva, ereta, rizomatosa, não ramificada, de caule angulado e densamente ferrugíneo-pubescente na parte superior, com 1-2 m de altura e nativa da América do Sul, com vasta ocorrência no Brasil, sendo uma das espécies importantes como infestantes na região Centro-Oeste. Propaga-se por sementes e rizomas. É uma planta daninha medianamente frequente, infestando principalmente pastagens, pomares, beira de estradas e terrenos baldios.

Memora peregrina (Miers) Sandwith é uma planta perene, ereta de ramos escandentes, lenhosa, pouca ramificada, com folhas de textura coriácea e áspera, de 80$140 \mathrm{~cm}$ de altura e nativa do Brasil. Propaga-se por sementes, contudo expande-se numa grande reboleira através de rizomas. É uma planta típica dos cerrados brasileiros que perpetua-se nestas áreas após a sua transformação em pastagens, tornando-se uma planta indesejável. Formam grandes reboleiras de difícil controle e/ou erradicação.

Tecoma stans (L.) Juss. ex Kunth é uma planta arbustiva ou pequena árvore de até $7 \mathrm{~m}$ de altura, ramificada, glabra, com casca quase lisa de cor pardo esverdeada e originária da América Central. Propaga-se com grande intensidade através de sementes. Planta muito cultivada como ornamental em todo o país, onde escapou para tornar-se uma séria planta daninha de pastagens e de terrenos baldios.

Ipomoea grandifolia (Dammer) O’Donell é uma planta anual, trepadeira, volúvel, herbácea, de caules com leve pilosidade translúcida, de 1-2 m de comprimento e nativa da América do Sul, incluindo o Brasil. Propaga-se apenas por sementes. É uma das plantas daninhas mais prejudiciais nas culturas anuais e perenes de verão das regiões Centro-Oeste, Sudeste e Sul do país.

Ipomoea purpurea (L.) Roth. é uma planta anual, trepadeira, herbácea, de caules com pilosidade brancacenta e estrelada, ramificada, com 1-3 m de comprimento e originária da América Tropical e Subtropical, ocorrendo em todo o território brasileiro, mas como infestante é mais comum na região Centro-Oeste. Propaga-se apenas por sementes. É uma das mais sérias infestantes de lavouras anuais existentes no país, principalmente em cereais colhidos mecanicamente. 
Euphorbia heterophylla L. é uma planta anual, ereta, herbácea, leitosa, de folhas muito variáveis, com caule glabro ou variavelmente pubescente, de 30-80 cm de altura e nativa do Continente Americano. É uma espécie de características variáveis, especialmente em relação ao formato das folhas. Propaga-se por sementes, ocorrendo principalmente em lavouras anuais e perenes.

Sida rhombifolia L. é uma planta anual ou perene, subarbustiva, ereta, de 30-80 cm de altura e nativa do Continente Americano. No Brasil é a espécie mais comum na região Sul, propagando-se por sementes. É uma planta daninha bastante frequente em solos cultivados ou não de todo o país. Infesta principalmente lavouras anuais e perenes, pomares, jardins, pastagens e terrenos baldios. É altamente competitiva com as culturas agrícolas devido ao seu profundo sistema radicular.

Sida glaziovii K. Schum. é uma planta perene, herbácea ou subarbustiva, ereta ou subprostrada, ramificada, de caule revestido de pubescência esbranquiçada, de 30$90 \mathrm{~cm}$ de altura e nativa do Brasil, ocorrendo com grande intensidade nas regiões Sudeste e Centro-Oeste. Propaga-se por sementes, infestando principalmente áreas destinadas a pastagens, beira de estradas, carreadores, pomares e culturas perenes em geral. Em áreas de pastagens assume hábito semiprostrado.

Nunes (1999) alerta que a infestação da ciganinha (Memora peregrina) já inviabilizou várias áreas de pastagens ou mesmo propriedades, por causa dos altos níveis de infestação e elevados custos para erradicá-la. Ainda destaca, que esta alta capacidade de infestação deve-se a eficientes formas de dispersão e propagação vegetativa, além das sementes aladas, possuem caules subterrâneos com grande capacidade de rebrote.

\subsection{Epiderme Foliar}

Dentre as funções da folha, estão a fotossíntese e a transpiração, sendo esta composta por três tipos de tecidos: epiderme, mesofilo e vasculares. Nas plantas é possível encontrar diferentes tipos de células epidérmicas: células típicas de epiderme; células ou grupo de células com estruturas, forma ou conteúdo especial; células estomáticas e apêndices epidérmicos ou tricomas (Fahn, 1990). As funções da epiderme são a regulação 
da água na planta, a proteção contra microrganismos, a proteção contra danos ambientais e como atrativos aos insetos para a reprodução das plantas, e é na epiderme que se localiza a interface entre a planta e o meio ambiente (Mauseth, 1988).

Todas as características da superfície foliar (topografia celular, grau e tipo de desenvolvimento de ceras epicuticulares, tricomas e glândulas) influenciam o depósito de herbicidas na superfície foliar. Há grande diversidade na morfologia epidérmica nas várias espécies de plantas, dentre elas: quantidade de estômatos, depósitos de ceras epicuticulares, depósitos diferenciados de ceras nas paredes periclinais das células guardas, promovendo absorção preferencial e grau de desenvolvimento de tricomas e glândulas (Hess \& Falk, 1990).

A cutícula consiste de cutina, ceras epicuticulares, ceras cuticulares e pectina. A espessura da cutícula varia de 0,1 a $10 \mu \mathrm{m}$, ainda apresenta capacidade de troca negativa em $\mathrm{pH}$ fisiológico. A cutícula tem ambas características lipofílicas e hidrofílicas. A maior parte do volume da cutícula consiste em cutina, que é composta principalmente de polimerizado de ácidos graxos hidroxilados (esterificado). Ceras cuticulares e epicuticulares são longas cadeias de alcano, contudo, uma pequena porcentagem (10 a 20 \%) são outras substâncias como álcoois graxos, aldeídos graxos, ácidos graxos e cetonas graxas. As ceras estão presentes nas superfícies foliares em duas formas: cristalina e amorfa. A pectina é composta principalmente de polímeros de ácido galacturônico, está na forma de tiras na base da cutícula (próximo da parede celular). A ordem crescente de lipofilicidade da cutícula é pectina<cutina<cera (Hess, 1997).

A cera epicuticular de muitas plantas mostra uma ampla diversidade na disposição física e nos constituintes químicos. As ceras epicuticulares são misturas complexas de alcanos de cadeia longa, álcoois, cetonas, aldeídos, ésteres e ácidos, mas os compostos são diferenciados em função da posição, número de grupos funcionais, grau de ramificação e insaturação (Eglinton \& Hamilton, 1967). As ceras epicuticulares podem ser encontradas na forma de placas, tubos, fitas, vara, filamentos e dentritos (Baker, 1991).

Os estômatos são normalmente constituídos por um poro elíptico, localizados na epiderme de folhas, caules herbáceos e partes florais, rodeados por duas células epidérmicas especializadas, as células guardas (Metcalfe \& Chalk, 1979). 
Estudos com microscopia eletrônica de varredura realizados por Schönherr \& Bukovac (1972) em folhas de Zebrina purpusii Bruckn. mostraram densidade estomática de 62,5 estômatos $/ \mathrm{mm}^{2}$, arranjados em fileiras paralelas às nervuras. Mcwhorter et al. (1993), observaram que a densidade estomática da superfície adaxial de folhas de Sorghum halepense varia de 25 a 106 estômatos/ $\mathrm{mm}^{2}$ (dispostos sobre as nervuras) e na superfície abaxial a densidade estomática foi de 76 a 129 estômatos $/ \mathrm{mm}^{2}$ (dispostos entre as nervuras em fileiras paralelas, separados por células longas). A densidade estomática em folhas de Erythroxylum coca, com 5 dias de idade, foi de 400 estômatos $/ \mathrm{mm}^{2}$ e, com 40 dias de idade, reduziu para 348 estômatos $/ \mathrm{mm}^{2}$. Em folhas de E. novogranatense, aos 5 dias de idade, a densidade foi de $379 / \mathrm{mm}^{2}$ e, aos 40 dias de idade, diminuiu para 170 estômatos/mm² (Mcwhorter \& Ouzts, 1994).

Mendonça (2000a), estudando os estômatos de plantas daninhas monocotiledôneas, observou em Cyperus rotundus L. a presença de apenas uma fileira de estômatos nos bordos foliares da superfície adaxial, e densidade estomática de 135 estômatos $/ \mathrm{mm}^{2}$ na superfície abaxial. Em Commelina benghalensis os estômatos encontraram-se dispersos de forma aleatória em ambas superfícies foliares. A maior densidade estomática dentre as espécies estudadas foi observada em Cynodon dactylon, com 384/329 estômatos $/ \mathrm{mm}^{2}$, na adaxial e abaxial, respectivamente.

Estudos sobre caracteres anatômicos de duas espécies de trapoeraba realizados por Santos et al. (2002), demonstraram que a densidade estomática de Commelina diffusa foi maior (38,00 estômatos $/ \mathrm{mm}^{2}$ ) do que a encontrada em $C$. benghalensis (33,66 estômatos $/ \mathrm{mm}^{2}$ ). Entretanto, a média da densidade estomática das duas espécies na epiderme adaxial foi 16,80 estômatos $/ \mathrm{mm}^{2}$ e na abaxial foi 54,86 estômatos $/ \mathrm{mm}^{2}$. Ainda utilizando a média da densidade estomática das duas superfícies foliares (adaxial e abaxial) conduzidas sob a influência do sol foram encontrados 37,89 estômatos $/ \mathrm{mm}^{2}$ e na sombra 33,77 estômatos $/ \mathrm{mm}^{2}$.

Mendonça (2000a), observou por meio de microscopia eletrônica de varredura a presença de maior depósito de ceras epicuticulares na superfície adaxial e menor na abaxial de Brachiaria decumbens, Brachiaria plantaginea, Cenchrus echinatus e Panicum maximum, e um semelhante depósito de ceras epicuticulares em ambas superfícies 
foliares de Cynodon dactylon, Digitaria horizontalis, D. insularis e Eleusine indica. Estes fatos refletiram em uma maior área de molhamento de soluções com diferentes tensões superficiais nas superfícies que apresentaram um menor depósito de ceras epicuticulares.

O tipo de superfície de cera influencia a capacidade de molhamento da solução de pulverização. Geralmente, a superfície foliar lisa, isenta de cristais de ceras epicuticulares, porém contém ceras amorfas que são relativamente fácil de molhar (como em muitas espécies de dicotiledôneas). Superfícies foliares cobertas com cristais de ceras epicuticulares são muito mais difíceis para molhar, como em muitas espécies de monocotiledôneas (Hess, 1997).

Harr et al. (1991) e Mendonça (2000a) determinaram a porcentagem de compostos polares e apolares das ceras epicuticulares, por meio de extração com clorofórmio e posterior separação em coluna de sílica gel com diferentes eluentes (hexano e clorfórmio). Mendonça (2000a) observou que Commelina benghalensis foi a espécie que apresentou maior quantidade de compostos apolares e Digitaria insularis a menor quantidade. Dentre as espécies estudadas pelos autores, C. rotundus apresentou resultados discordantes com relação aos compostos polares e apolares.

Muitos trabalhos sobre características anatômicas de folhas de plantas daninhas vêm sendo realizados no Brasil (Albert \& Victoria Filho, 2002; Ferreira et al., 2002; Santos et al., 2002; Ferreira et al., 2003; Monquero, 2003; Tuffi Santos et al., 2004), evidenciando a importância deste tipo de linha de pesquisa na área da Ciência das Plantas Daninhas. Mendonça (2003) agregou à essa linha de pesquisa o estudo do efeito do herbicida chlorimum-ethyl (Classic) associado ou não ao óleo mineral Assist sobre a estrutura das ceras epicuticulares de folhas de soja e algumas plantas daninhas, e concluiu que tais efeitos são específicos para cada interação superfície foliar (espécie) com tipo de solução pulverizada. 


\subsection{Aplicação e Deposição dos Herbicidas no Alvo}

Para o sucesso de pulverizações de agroquímicos, é fundamental o conhecimento das influências intrínsecas às plantas (disposição das folhas, pH foliar, ceras epicuticulares, estômatos, tricomas, etc) e influências extrínsecas, como características físico-químicas da solução de pulverização (tensão superficial, área de molhamento, pH da solução, tipo de formulação, etc) (Mendonça, 2000a).

Segundo Wirth et al. (1991), a aplicação do ingrediente ativo começa com a preparação da solução de pulverização e é seguida pela pulverização, trajetória e impacto na superfície da folha, salientando que para obter a máxima eficácia na aplicação cada passo deve ser otimizado. Segundo Kirkwood (1999), as propriedades físico-químicas da cutícula influenciam o comportamento da gota de pulverização, podendo afetar a taxa e eficiência da penetração cuticular. A difusão do ingrediente ativo é influenciada por suas características de solubilidade, indicada pelos coeficientes de partição octanol/água ( $\left.\mathrm{K}_{\mathrm{oa}}\right)$ e cutícula/água $\left(\mathrm{K}_{\mathrm{ca}}\right)$. A remoção das ceras promove um aumento na sorção, pelo fato de tornar acessíveis sítios adicionais à sorção (Bukovac \& Petracek, 1993).

Segundo Hess (1997), dentre os fatores que influenciam a quantidade e distribuição de herbicidas na superfície foliar, afetando a absorção, estão: a) tensão superficial da solução de pulverização; b). a molhabilidade da superfície foliar que depende da quantidade de cera cuticular e estrutura física das ceras e dos tricomas da superfície foliar; c) a orientação da folha com respeito à chegada das gotas de pulverização; d) o total de área foliar por planta (probabilidade de interceptar a gota de pulverização).

Na aplicação de agroquímicos, Bukovac \& Petracek (1993) acreditam que a penetração foliar começa quando a solução é retida pela superfície da planta. Esse é um processo contínuo, consistindo de três etapas: sorção, difusão e desorção. A sorção consiste na distribuição do ingrediente ativo entre a solução aquosa de pulverização e a cutícula. O soluto é então difundido através da cutícula e, quando as moléculas chegam na interface da superfície cutícula/parede celular, elas são desorvidas da cutícula no apoplasto aquoso. Para simplificar pode-se exemplificar a penetração cuticular como a 
difusão do soluto de um doador aquoso (solução de pulverização), através da cutícula (membrana), em um receptor aquoso (apoplasto). Segundo Schreiber \& Schönherr (1992), o equilíbrio desse processo estabiliza-se em 30 minutos e após esse período, a absorção representa a penetração da molécula para o interior das células foliares (simplasto). Ainda, outro determinante da permeabilidade é a baixa mobilidade dos solutos nas ceras epicuticulares.

Os produtos fitossanitários geralmente devem ser depositados nas superfícies de folhas, ramos e frutos e, para uma boa compatibilidade física entre essas superfícies e as caldas de pulverização, deve-se levar em consideração a espécie da planta, a idade dos órgãos e as condições ambientais (Kissmann, 1997).

\subsection{Absorção e Translocação de Herbicidas}

A absorção foliar de herbicidas é um processo complexo, envolvendo a passagem das moléculas de herbicida da superfície externa da folha, através da cutícula, para o interior do tecido. A passagem das moléculas de herbicida para dentro da folha é função da natureza química e física da cutícula, as propriedades dos herbicidas, a formulação de ingrediente ativo, o ambiente em que a folha desenvolveu-se e o ambiente em que ocorreu a absorção. Considerar todas essas variáveis e combiná-las em um modelo geral de absorção de herbicidas seria ideal, no entanto existem muitos fatores que governam a absorção de herbicidas, e que cada combinação herbicida / planta / formulação / ambiente tem suas próprias características (Devine et al., 1993).

O processo de absorção do ingrediente ativo inicia-se logo após o contato da solução de pulverização com a superfície foliar. Observações obtidas por Mendonça (2000b), mostraram que, em 20 minutos após a pulverização, 10,72\% do herbicida propanil pulverizado sobre folhas de arroz já havia sido absorvido neste curto período. No entanto, após 8 horas da aplicação apenas 16,63\% do herbicida havia sido absorvido, observando que o incremento na absorção foi pequeno em função do tempo.

Várias pesquisas têm sido feitas envolvendo a absorção e translocação de 2,4-D em diferentes espécies vegetais como Silene vulgaris (Moench) Garcke (Wall et 
al., 1991), Sisymbrium orientale Torn. (Wolf et al. 1992), Apocynum cannabinum L. (Schultz \& Burnside, 1980; Wyrill \& Burnside, 1976) e Asclepias syriaca L. (Wyrill \& Burnside, 1976). Porém, muitos autores também avaliaram a absorção e translocação de 2,4-D em associação com picloram no controle de Euphorbia esula L. (Nelson \& Lym, 2003; Thompson et al., 1996; Lym \& Moxness, 1989) e de Isocoma drummondii (T. \& G.) Greene (Mayeux \& Scifres, 1980). A associação do herbicida 2,4-D com o picloram tem sido usada com grande sucesso como método de controle químico para estas espécies.

O aumento do picloram não metabolizado no sistema radicular de Euphorbia esula quando o 2,4-D foi aplicado com picloram comparado com a aplicação do picloram sozinho, pode ser a razão para o aumento no controle desta planta daninha (Lym \& Moxness, 1989).

No Brasil, estudos de absorção com o herbicida diuron radiomarcado realizados por Dias et al. (2003) demonstraram que após 48 horas da aplicação do diuron foram encontrados 29 \% do produto aplicado em plantas de Digitaria ciliaris e $39 \%$ do em plantas de Digitaria. nuda. Na mesma linha, Monquero (2003) estudou a absorção, translocação e metabolismo de glyphosate radiomarcado em algumas espécies de plantas daninhas (Amaranthus hybridus, Ipomoea grandifolia e Commelina benghalensis) e soja resistente e suscetível a este herbicida, e concluiu que $90 \%$ do herbicida aplicado havia sido absorvido 72 horas após a aplicação em plantas de $A$. hybridus, soja resistente e suscetível. Na espécie daninha I. grandifolia esta taxa de absorção foi de $80 \%$ e em $C$. benghalensis foi $66 \%$. 


\section{CARACTERÍSTICAS DAS SUPERFÍCIES FOLIARES DE PLANTAS DANINHAS. I - APOCYNACEAE: Peschiera fuchsiaefolia e ASTERACEAE: Vernonia polyanthes e Vernonia westiniana}

\section{Resumo}

Nas folhas, a superfície externa é caracterizada pela presença de epiderme foliar, e presente nesta estão estruturas tais como ceras epicuticulares, estômatos, tricomas e apêndices. A molhabilidade e a penetração do agroquímico depende de muitos fatores, dentre eles o contato da solução pulverizada com os constituintes da cutícula foliar. O objetivo desta pesquisa foi avaliar a densidade estomática, a porcentagem de compostos polares e apolares das ceras epicuticulares e observar as características ultra-estruturais da cutícula foliar de Peschiera fuchsiaefolia, Vernonia polyanthes e Vernonia westiniana. O número de estômatos por unidade de área de epiderme foliar (densidade estomática) foi determinado em ambas superfícies foliares das espécies vegetais, utilizando a técnica de impressão da epiderme foliar em lâmina de vidro com cola adesiva. Na determinação dos compostos polares e apolares das ceras epicuticulares, as folhas foram imersas em clorofórmio e as amostras foram fracionadas em coluna de sílica gel, onde com o solvente hexano obteve-se os compostos apolares e com o clorofórmio, os polares. Para avaliação da quantidade de cera por unidade de área foliar foi determinada a área foliar destas folhas após a imersão em clorofórmio. A análise ultra-estrutural de superfícies foliares foi realizada observando imagens obtidas com a Microscopia Eletrônica de Varredura. A espécie P. fuchsiaefolia apresentou estômatos em ambas superfícies foliares, com densidade estomática de 11,8 e 209,4 estômatos $/ \mathrm{mm}^{2}$ de área foliar (adaxial e abaxial), tricomas curtos na superfície adaxial e 41,9 $\mu \mathrm{g}$ de cera/ $\mathrm{cm}^{2}$, sendo $11,2 \%$ de compostos apolares e 88,8 \% de polares. As densidades estomáticas encontradas nas superfícies foliares adaxial e abaxial de $V$. polyanthes 
foram 36,5 e 99,7 estômatos $/ \mathrm{mm}^{2}$ e em $V$. westiniana 45,2 e 154,9 estômatos $/ \mathrm{mm}^{2}$. As espécies estudadas do gênero Vernonia apresentaram tricomas glandulares em ambas superfícies, tricomas multicelulares curtos na superfície adaxial e tricomas unicelulares na abaxial. Na espécie $V$. polyanthes encontrou-se 31,1 $\mu$ g de cera $/ \mathrm{cm}^{2}$, sendo $15,0 \%$ compostos apolares e 85,0\% polares, enquanto a espécie $V$. westiniana apresentou maior quantidade de cera $\left(42,9 \mu \mathrm{g}\right.$ de cera/ $\left.\mathrm{cm}^{2}\right)$, sendo $7,6 \%$ de compostos apolares e 92,4 \% de polares. Todas as espécies estudadas apresentaram ceras epicuticulares com estruturas amorfas.

FOLIAR SURFACES CHARACTERISTICS OF WEEDS. I - APOCYNACEAE: Peschiera fuchsiaefolia and ASTERACEAE: Vernonia polyanthes and Vernonia westiniana

\section{Summary}

In the leaves, the external surface is characterized by presence of epidermis and this surface contains epicuticular waxes, stomatas, trichomes and appendixes. The wettability and the penetration of the pesticide depend on many factors, like the contact of the solution sprayed with the foliar cuticle. The objective of this research was to evaluate the stomatal density, the polar and apolar compounds percentage of the epicuticular waxes and to analyze the ultra-structural of the cuticle of Peschiera fuchsiaefolia, Vernonia polyanthes and Vernonia westiniana. The number stomata for unit of foliar area (stomatal density) was determined in both foliar surfaces of the plants, with the impression of the foliar epidermis in sheet of glass using glue. In the determination of the polar and apolar compounds of the epicuticular waxes, the leaves were dipped in chloroform and the samples were divided using a column of silica gel, where the solvent hexane extracted the apolar compounds and the chloroform extracted the polar compounds from this column. The leaves were dipped in chloroform to extract the epicuticular wax and after were determined foliar area. The ultra-structural analyses of the foliar surfaces were determined observing images obtained with Scanning Electronic Microscopy. In the specie $P$. fuchsiaefolia the stomatas were in both foliar surfaces, with stomatal 
density of 11.8 and 209.4 stomata $/ \mathrm{mm}^{2}$ of foliar area (adaxial and abaxial), short trichomes were in the adaxial surface and this plant had $41.9 \mu \mathrm{g}$ of $\mathrm{wax} / \mathrm{cm}^{2}$, being $11.2 \%$ of apolar compounds and $88.8 \%$ of polar. The stomatal densities found in the adaxial and abaxial foliar surfaces of $V$. polyanthes were, respectively, 36.5 and 99.7 stomata $/ \mathrm{mm}^{2}$ and in $V$. westiniana were 45.2 and 154.9 stomata $/ \mathrm{mm}^{2}$. Vernonia genus presented glandular trichomes in both surfaces, short multicellular trichomes in the adaxial surface and unicellular tricomas in the abaxial. In the specie $V$. polyanthes was extracted $31.1 \mu \mathrm{g}$ of wax $/ \mathrm{cm}^{2}$, being $15.0 \%$ apolar compounds and 85.0\% polar, whereas in the specie $V$. westiniana presented more amount of wax (42.9 $\mu$ g of wax $/ \mathrm{cm}^{2}$ ), being $7.6 \%$ of apolar compounds and $92.4 \%$ of polar. All the studied species presented epicuticular waxes with amorphous structures.

\subsection{Introdução}

As plantas daninhas competem com as plantas cultivadas por água, luz e nutrientes, e em certas ocasiões são tóxicas aos animais, como no caso de algumas invasoras de pastagens. A presença destas espécies provoca limitações no desenvolvimento das plantas cultivadas, pois interferem tanto em culturas anuais e perenes como em pastagens.

Em aplicações de herbicidas em pós-emergência, as folhas representam a principal rota de entrada destes herbicidas nas plantas e a eficácia nesta absorção poderá definir o nível de controle. Nas folhas localizam-se várias estruturas funcionais, como as ceras e os estômatos, além da presença de tricomas, apêndices, tricomas glandulares, entre outras. O conhecimento dessas estruturas funcionais elucida as possíveis interações entre os herbicidas e as superfícies foliares das plantas daninhas, durante o processo de absorção. Após a absorção do herbicida pela planta, este poderá ser translocado ou não, fato este definido principalmente pelas características químicas da molécula, chegando ao seu sítio de ação e causando a morte da planta daninha.

As plantas daninhas estudadas são infestantes principalmente de áreas de pastagens, da Classe Dicotiledônea e que comumente são chamadas de folhas largas. Na 
Tabela 1 estão apresentadas informações quanto à família, nome científico, nomes comuns e código internacional de cada espécie.

Tabela 1. Famílias, espécies, nomes comuns e códigos internacionais das espécies de plantas daninhas dicotiledôneas

\begin{tabular}{rllc}
\hline Família & \multicolumn{1}{c}{ Nome Científico } & \multicolumn{1}{c}{ Nome Comum } & Cód. Int. \\
\hline Apocynaceae & $\begin{array}{l}\text { Peschiera fuchsiaefolia (A. } \\
\text { DC.) Miers }\end{array}$ & Leiteiro, leiteira & TAEFU \\
Asteraceae & Vernonia polyanthes Less. & $\begin{array}{l}\text { Assa-peixe, assa peixe-branco, } \\
\text { cambará-guaçú, cambará-açú, } \\
\end{array}$ & VENPO \\
& & $\begin{array}{l}\text { cambará-branco, chamarrita (SC) } \\
\text { Aernonia westiniana Less. }\end{array}$ & \\
& Assa-peixe, chamarrita (SC) & VENWE \\
\hline
\end{tabular}

Fonte: Lorenzi (2000).

Lorenzi (2000) e Kissmann \& Groth (1999) descrevem Peschiera fuchsiaefolia (A. DC.) Miers como uma planta perene, nativa do Brasil e que se propaga por sementes e através de profundos rizomas. É uma séria infestante de pastagens em quase todo o país, possuindo grande habilidade reprodutiva e alta rusticidade (pouco exigente na fertilidade do solo).

Dentre as espécies estudadas da Família Asteraceae, Lorenzi (2000) e Kissmann \& Groth (1999) descrevem a espécie Vernonia polyanthes Less. como uma planta perene, nativa do território brasileiro, a qual se propaga por sementes. É uma das plantas daninhas mais freqüentes e mais temidas das nossas pastagens chegando a anular a capacidade de lotação do pasto. Estes autores descrevem ainda a espécie Vernonia westiniana Less. como uma planta perene, nativa da América do Sul e que se propaga por sementes e rizomas. É uma planta daninha medianamente freqüente, infestando principalmente pastagens, pomares, beira de estradas e terrenos baldios, sendo importante como infestante na região Centro-Oeste.

Todas as características das superfícies foliares influenciam o depósito de herbicidas na superfície foliar. As várias espécies de plantas apresentam grande diversidade na morfologia epidérmica (estômatos, ceras epicuticulares, tricomas e glândulas) (Hess \& Falk, 1990). Então, para o sucesso de pulverizações de agroquímicos, é fundamental tanto o conhecimento das influências intrínsecas às 
plantas (características da epiderme foliar) como das influências extrínsecas (características físico-químicas da solução de pulverização) (Mendonça, 2000a).

A cutícula consiste de cutina, ceras epicuticulares, ceras cuticulares e pectina. A espessura da cutícula varia de 0,1 a $10 \mu \mathrm{m}$ entre as espécies vegetais. A cutina é composta principalmente de polimerizado de ácidos graxos hidroxilados (esterificados). As ceras cuticulares e epicuticulares são longas cadeias de alcano, além de outras substâncias como álcoois graxos, aldeídos graxos, ácidos graxos e cetonas graxas, estando presentes nas superfícies foliares na forma cristalina ou amorfa. A pectina é composta principalmente de polímeros de ácido galacturônico, disposta na forma de tiras na base da cutícula (próxima da parede celular). A ordem crescente de lipofilicidade da cutícula é pectina<cutina<cera (Hess, 1997).

As ceras epicuticulares podem ser encontradas na forma de placas, tubos, fitas, vara, filamentos e dentritos (Baker, 1991). O tipo de estrutura de cera influencia a capacidade de molhamento da solução de pulverização, assim em superfícies foliares lisas, como em muitas espécies dicotiledôneas, são relativamente fáceis de molhar. Superfícies foliares cobertas com cristais de ceras epicuticulares são muito mais difíceis para molhar, como em muitas espécies de monocotiledôneas (Hess, 1997).

Na aplicação de agroquímicos, Bukovac \& Petracek (1993) acreditam que a penetração foliar começa quando a solução é retida pela superfície da planta. Esse é um processo contínuo, consistindo de três etapas: sorção, difusão e desorção.

Segundo Wirth et al.(1991), a aplicação do ingrediente ativo começa com a preparação da solução de pulverização e é seguida pela pulverização, trajetória e impacto na superfície da folha, salienta ainda que para obter a máxima eficácia na aplicação cada passo deve ser otimizado. Segundo Kirkwood (1999), as propriedades físico-químicas da cutícula influenciam o comportamento da gota de pulverização, podendo afetar a taxa e eficiência da penetração cuticular. A remoção das ceras promove um aumento na sorção, pelo fato de tornar acessíveis sítios adicionais à absorção (Bukovac \& Petracek, 1993).

Segundo Hess (1997), os fatores que influenciam na quantidade e distribuição de herbicidas na superfície foliar são: a tensão superficial da solução de 
pulverização, a quantidade de cera cuticular e estrutura física das ceras e dos tricomas da superfície foliar, a orientação da folha e o total de área foliar por planta.

Os produtos fitossanitários geralmente devem ser depositados nas superfícies de folhas, ramos e frutos e, para uma boa compatibilidade física entre essas superfícies e as caldas de pulverização, deve-se levar em consideração a espécie da planta, a idade dos órgãos e as condições ambientais (Kissmann, 1997).

O objetivo desta pesquisa foi estudar as características ultra-estruturais das superfícies foliares das seguintes plantas daninhas: Peschiera fuchsiaefolia (A. DC.) Miers, Vernonia polyanthes Less. e Vernonia westiniana Less., pela determinação da densidade estomática, da caracterização das ceras epicuticulares determinando sua massa e a porcentagem de compostos polares e apolares e observações usando a microscopia eletrônica de varredura.

\subsection{Material e Métodos}

As plantas foram cultivadas em condições de casa-de-vegetação do Departamento de Produção Vegetal da ESALQ/USP, com temperatura variando de 15 a $35^{\circ} \mathrm{C}$, com turno de irrigação diário. O solo utilizado para o cultivo das plantas daninhas apresentava as seguintes características físicas: 64\% de areia total, 26 \% de argila e 10 \% de silte, classificado como textura média argilosa. As características químicas do solo utilizado estão apresentadas na Tabela 2. As plantas daninhas avaliadas encontravam-se com aproximadamente $30 \mathrm{~cm}$ de altura.

Tabela 2. Características químicas do solo (macronutrientes e micronutrientes). Piracicaba, SP, 2004

\begin{tabular}{|c|c|c|c|c|c|c|c|c|c|c|c|c|c|c|}
\hline $\mathrm{pH}$ & M. O. & B & $\mathrm{Cu}$ & $\mathrm{Fe}$ & $\mathrm{Mn}$ & $\mathrm{Zn}$ & $\mathrm{P}_{\text {resina }}$ & $\mathrm{H}+\mathrm{Al}$ & K & $\mathrm{Ca}$ & $\mathrm{Mg}$ & SB & CTC & V\% \\
\hline $\mathrm{CaCl}_{2}$ & g.dm ${ }^{-3}$ & $\ldots$ & $\cdots$ & $\ldots \mathrm{m}$ & $\mathrm{dm}^{-3}$. & & & $\ldots \ldots$ & ...... &. $\mathrm{mmo}$ & ${ }_{\mathrm{c} .} \mathrm{dm}^{-1}$ & & & \\
\hline 5,4 & 11 & 0,14 & 0,6 & 4 & 3,4 & 0,8 & 4 & 12 & 0,1 & 31 & 25 & 56,1 & 68,1 & 82 \\
\hline
\end{tabular}

\subsubsection{Densidade estomática}


O número de estômatos por unidade de área de epiderme foliar (densidade estomática) foi determinado nas superfícies adaxial e abaxial das folhas das plantas daninhas. Utilizou-se a técnica de impressão de epiderme em adesivo a base de éster de cianoacrilato (Mendonça, 2000a). Para tanto, uma gota do adesivo foi depositada em lâmina de vidro para microscopia, colocando a folha com a superfície desejada voltada para a cola pressionando-a na lâmina. Após secagem do adesivo, o material vegetal foi retirado, permanecendo a impressão da epiderme na lâmina. A densidade estomática foi determinada em microscópio ótico de luz (Marca Carl Zeiss, Modelo Axio skop 2), acoplado ao computador com o software Axiovision. Nas avaliações da densidade estomática das superfícies foliares foram utilizadas 50 repetições. Os dados foram analisados estatisticamente pelo valor de $t$ ( $\mathrm{P}>0,05)$, determinando os intervalos de confiança mínimo e máximo. Também foi analisado o nível de significância em que as médias das superfícies foliares (adaxial e abaxial) foram diferentes, pelo Teste $t$ entre as duas superfícies, utilizando o software Excel.

\subsubsection{Separação dos compostos polares e apolares}

Os compostos polares e apolares das ceras epicuticulares foram separados segundo metodologia utilizada por Mendonça (2000a). As ceras foram extraídas mergulhando as folhas em clorofórmio por 30 segundos, tomando-se o cuidado para não expor o corte ao solvente, determinou-se a área foliar das folhas para determinação da quantidade de $\mu$ g de cera/ $\mathrm{cm}^{2}$. A amostra foi filtrada em papel de filtro e o solvente foi evaporado. Para as determinações de ceras totais as alíquotas foram transferidas para vials de $4 \mathrm{~mL}$, secas totalmente e pesadas em balança com precisão de 0,0001 g. Para o fracionamento de compostos polares e apolares a cera foi redissolvida em 0,5 mL de clorofórmio, colocada em coluna empacotada de sílica gel (SiOH). Esta coluna foi mantida a vácuo para total secagem do solvente e em seguida foi realizada a seguinte sequência de solventes: $20 \mathrm{~mL}$ de hexano e $20 \mathrm{~mL}$ de clorofórmio, sendo estes solventes coletados separadamente. Foram obtidas duas frações da amostra, onde a fração extraída 
pelo hexano correspondeu a apolar e a extraída pelo clorofórmio a menos apolar, chamada de "polar”. Os solventes foram evaporados e pesados em balança de precisão de $0,0001 \mathrm{~g}$.

3.2.3 Análise ultra-estrutural da epiderme foliar

Os estudos ultra-estruturais da epiderme foliar foram realizados através de Microscopia Eletrônica de Varredura (MEV), caracterizando as faces adaxial e abaxial da região mediana da lâmina foliar das espécies de plantas daninhas e foram conduzidos no Núcleo de Apoio à Pesquisa/ Microscopia Eletrônica Aplicada à Pesquisa Agropecuária (NAP/MEPA), da ESALQ/USP.

Protocolo de preparo de amostra para observação em microscópio eletrônico de varredura (Kitajima \& Leite, 1999): amostras foliares com dimensões aproximadas de 2x2 mm, foram fixadas em solução de fixador "Karnovsky" (glutaraldeído 2,5 \%, formaldeído 2,5 \% em tampão cacodilato de sódio 0,05 M, pH 7,2, $\mathrm{CaCl}_{2}$ 0,001 M), por uma hora. Em seguida, as amostras foram lavadas em tampão cacodilato 0,05 M por três vezes e pós-fixadas em tetraóxido de ósmio 1 \% em tampão cacodilato 0,05 M, pH 7,2 por uma hora em temperatura ambiente. As amostras fixadas no tetraóxido de ósmio foram lavadas com água destilada e desidratadas por uma série de concentração crescente de acetona (30, 50, 70 e 90 \%) uma vez cada por 10 minutos e em 100 \% de acetona por três vezes de 10 minutos. Nas amostras realizou-se a secagem ao ponto crítico com a finalidade de retirar a acetona das amostras foliares, substituindo-a por $\mathrm{CO}_{2}$ líquido, em seguida mudando seu estado físico para gasoso (Marca Balzers e Modelo CPD 050). Em seguida as amostras foram metalizadas com ouro (Marca Balzers e Modelo MED 010).

Os materiais foram observados ao Microscópio Eletrônico de Varredura da Marca Zeiss e do Modelo DSM900. As imagens selecionadas nas observações ao microscópio eletrônico de varredura foram trabalhadas no software Corel Photo-Paint 9.0 para montagem das figuras.

\subsection{Resultados e Discussão}




\subsubsection{Apocynaceae: Peschiera fuchsiaefolia}

As características da superfície foliar são representadas pela densidade estomática, pela quantidade de ceras epicuticulares, bem como pela proporção de compostos polares e apolares e a apresentação das imagens obtidas por microscopia eletrônica de varredura.

Na Tabela 3 estão apresentadas as densidades estomáticas da espécie $P$. fuchsiaefolia, a superfície adaxial apresentou 11,8 estômatos por $\mathrm{mm}^{2}$ e a abaxial 209,4 estômatos por $\mathrm{mm}^{2}$, diferindo estatisticamente pelos intervalos de confiança e pela baixa probabilidade das superfícies foliares não diferirem (5,22E-51).

Nesta espécie a proporção entre o número de estômatos da superfície adaxial e a abaxial foi de 1:17,7, ou seja, em uma mesma região foliar, para cada estômato da superfície adaxial existiam 17,7 na superfície abaxial. Esta característica anatômica contribui com a rusticidade desta espécie, pois os estômatos são responsáveis pelas perdas de água da planta (Taiz \& Zeiger, 2004), reduzindo as perdas de água pela superfície adaxial, reforçando a habilidade de sobreviver em condições de estresse hídrico, sendo esta uma planta daninha importante infestante de pastagens, sobrevivendo na época da seca.

Outra planta agressiva observada por Mendonça (2000a) foi Cyperus rotundus L. no qual apresentou apenas uma fileira de estômatos nos bordos foliares da superfície adaxial, e densidade estomática de 135 estômatos $/ \mathrm{mm}^{2}$ na superfície abaxial. Como esta planta daninha é agressiva quanto à sua dispersão e sobrevivência em diversos ambientes, esta característica anatômica do posicionamento dos seus estômatos no limbo foliar somam-se a sua habilidade como planta daninha.

Tabela 3. Densidade estomática de Peschiera fuchsiaefolia (leiteiro). Piracicaba, SP, 2004 


\begin{tabular}{|c|c|c|}
\hline & \multicolumn{2}{|c|}{ Densidade estomática (estômatos $/ \mathrm{mm}^{2}$ ) } \\
\hline Média & 11,8 & 209,4 \\
\hline IC mínimo ${ }^{1}$ & 9,6 & 202,4 \\
\hline IC máximo ${ }^{1}$ & 14,0 & 216,4 \\
\hline$P(T<=t)^{2}$ & \multicolumn{2}{|c|}{$5,22 \mathrm{E}-51$} \\
\hline
\end{tabular}

${ }^{1}$ IC: intervalo de confiança (t à $5 \%$ de probabilidade).

${ }^{2}$ Teste t: duas amostras presumindo variâncias diferentes.

A quantidade de cera obtida em $P$. fuchsiaefolia foi $41,9 \mu \mathrm{g} / \mathrm{cm}^{2}$ e o valor da fração polar foi 88,8 \% e da fração apolar correspondeu à apenas 11,2 \%, como pode ser verificado na Tabela 4.

Tabela 4. Quantidade de ceras epicuticulares presentes nas de Peschiera fuchsiaefolia (leiteiro). Piracicaba, SP, 2004

\begin{tabular}{cc}
\hline Parâmetro & Média \\
\hline Cera epicuticular $\left(\mu \mathrm{g} / \mathrm{cm}^{2}\right)$ & 41,9 \\
Fração apolar (\%) & 11,2 \\
Fração polar (\%) & 88,8 \\
\hline
\end{tabular}

Nas Figuras 1 e 2 estão apresentadas as superfícies foliares de plantas de $P$. fuchsiaefolia. Na superfície adaxial observou-se a presença de tricoma curtos, uma reduzida quantidade de estômatos e ocorreram depósitos de ceras epicuticulares amorfos. A superfície abaxial apresentou uma maior densidade estomática, e os estômatos foram classificados quanto a sua forma como anomocítico (Mauseth, 1988). As superfícies foliares das duas faces foram semelhantes quanto ao formato das células epidérmicas e a estrutura do depósito de cera epicuticular amorfa. 

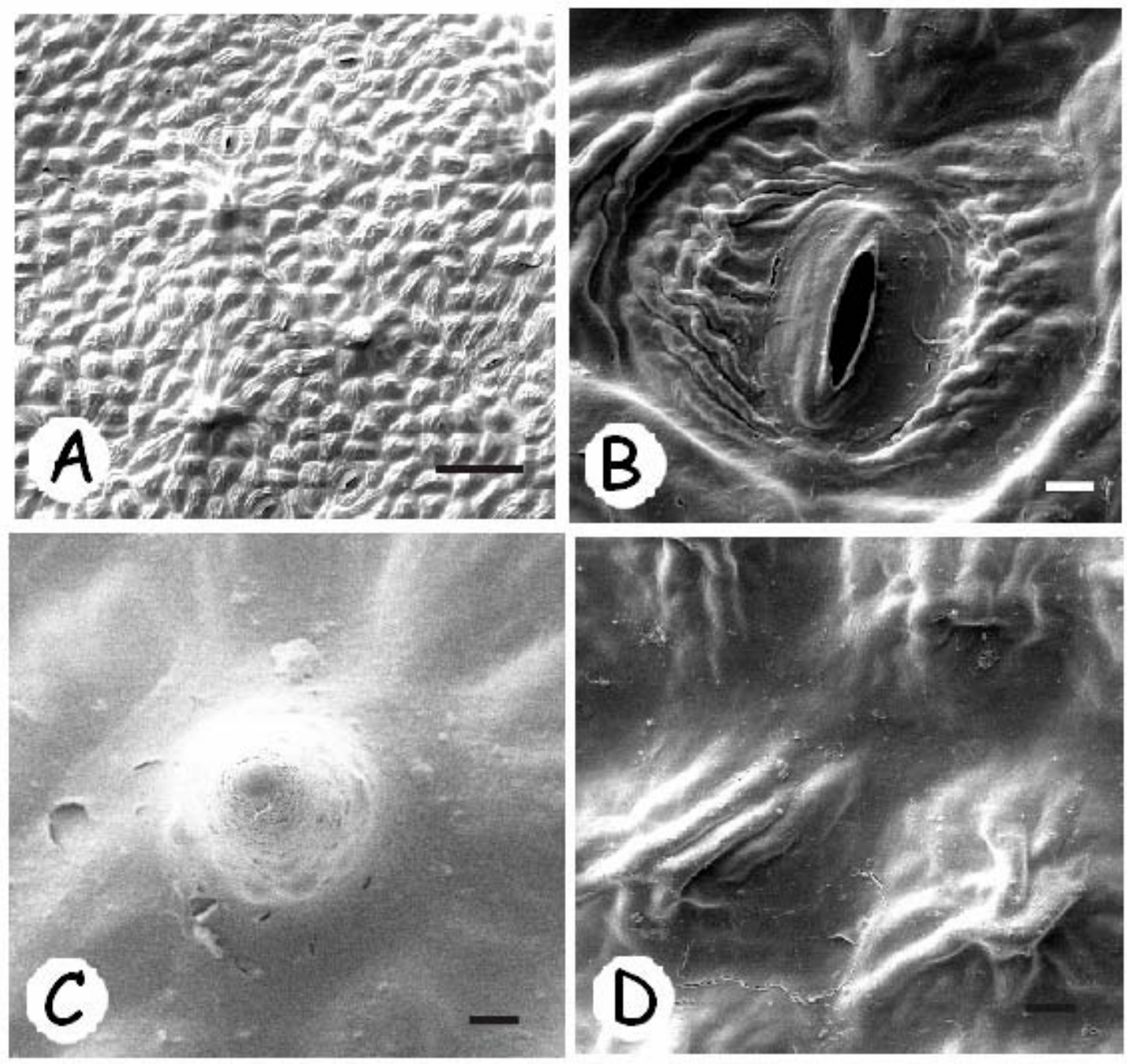

Figura 1 - Superfície foliar adaxial de Peschiera fuchsiaefolia (leiteiro). A: Visão geral da superfície foliar (200x); B: Detalhe do estômato (2000x); C: Detalhe do tricoma (2000x); D: Detalhe das células epidérmicas (2000x). Barras: $100 \mu \mathrm{m}, 5 \mu \mathrm{m}, 5 \mu \mathrm{m}$ e $5 \mu \mathrm{m}$, respectivamente 

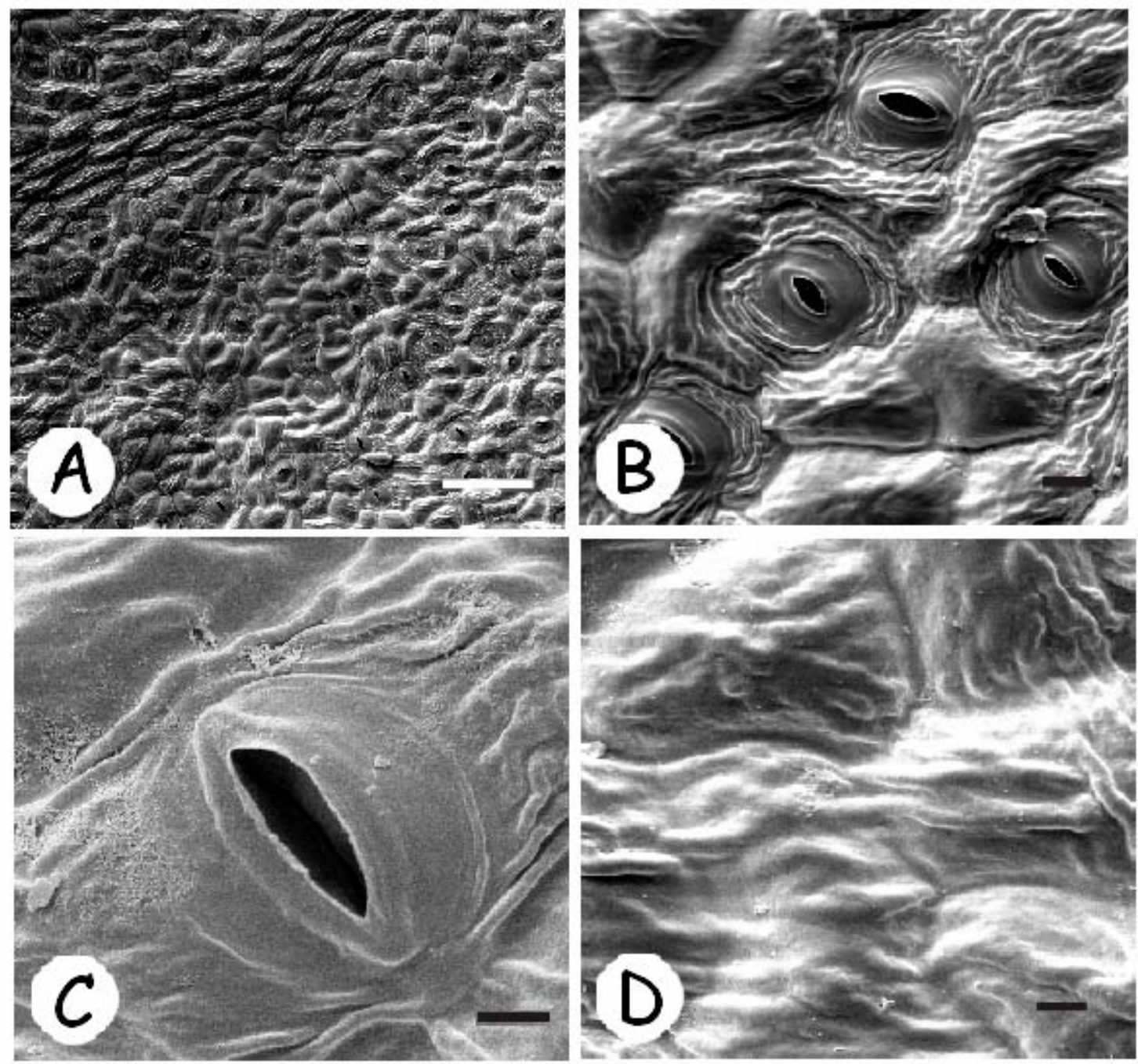

Figura 2 - Superfície foliar abaxial de Peschiera fuchsiaefolia (leiteiro). A: Visão geral da superfície foliar (200x); B: Estômatos (1000x); C: Detalhe do estômato (3000x); D: Detalhe das células epidérmicas (2000x). Barras: $100 \mu \mathrm{m}, 10 \mu \mathrm{m}, 5 \mu \mathrm{m}$ e $5 \mu \mathrm{m}$, respectivamente 
Tanto na espécie $V$. polyanthes como na $V$. westiniana observou-se diferença na densidade estomática entre as superfícies foliares adaxial e abaxial. A probabilidade das superfícies não diferirem quanto à densidade estomática através da análise estatística foi 3,86E-22 para $V$. polyanthes e 2,63E-24 em $V$. westiniana. Estes estômatos foram classificados quanto à forma como anomocíticos, ou seja, as células subsidiárias não estão bem diferenciadas das células epidérmicas (Mauseth, 1988).

A densidade estomática da superfície adaxial de $V$. polyanthes e $V$. westiniana não diferem estatisticamente, pois seus intervalos de confiança sobrepõem-se (Tabela 5). A determinação da correlação dos dados de densidade estomática da superfície adaxial das duas espécies mostrou-se positiva, comprovando as conclusões através dos dados de intervalos de confiança. Na superfície abaxial as densidades estomáticas foram diferentes quando comparada entre as espécies estudadas do gênero Vernonia, sendo assim, não foi observada correlação positiva entre as superfícies abaxiais.

Mcwhorter \& Ouzts (1994) estudando a densidade estomática de folhas de plantas do gênero Erythroxylum, determinaram que em folhas de Erythroxylum coca, com cinco dias de idade a densidade foi de 400 estômatos $/ \mathrm{mm}^{2}$ e com 40 dias de idade esta reduziu para 348 estômatos $/ \mathrm{mm}^{2}$. Em folhas de E. novogranatense, aos 5 dias de idade, a densidade estomática foi de $379 / \mathrm{mm}^{2}$ e com 40 dias de idade diminuiu para 170 estômatos $/ \mathrm{mm}^{2}$.

Santos et al. (2002) observaram que a densidade estomática de Commelina diffusa foi maior (38,00 estômatos $/ \mathrm{mm}^{2}$ ) do que a encontrada em $C$. benghalensis (33,66 estômatos/ $\mathrm{mm}^{2}$ ).

Tabela 5. Densidade estomática de Vernonia polyanthes (assa-peixe) e Vernonia westiniana (assa-peixe). Piracicaba, SP, 2004

Densidade estomática (estômatos $/ \mathrm{mm}^{2}$ )

$V$. polyanthes

$V$. westiniana 


\begin{tabular}{ccccc} 
& adaxial & abaxial & adaxial & abaxial \\
\hline Média & 36,5 & 99,7 & 45,2 & 154,9 \\
IC mínimo $^{1}$ & 32,0 & 91,6 & 39,0 & 142,1 \\
IC máximo $^{1}$ & 41,1 & 107,7 & 51,3 & 167,7 \\
$\mathrm{P}(\mathrm{T}<=\mathrm{t})^{2}$ & \multicolumn{2}{c}{$3,86 \mathrm{E}-22$} & \multicolumn{2}{c}{$2,63 \mathrm{E}-24$} \\
Correlação $^{2}$ & 0,72 & $-0,06$ & 0,72 & $-0,06$ \\
\hline
\end{tabular}

${ }^{1}$ IC: intervalo de confiança (t à $5 \%$ de probabilidade).

${ }^{2}$ Teste t: duas amostras presumindo variâncias diferentes.

A espécie $V$. polyanthes apresentou em média 31,1 $\mu$ g de cera $/ \mathrm{cm}^{2}$ e deste total 15,0 \% são compostos apolares e 85,0 \% polares, mostrando assim que esta espécie tem uma maior quantidade de compostos polares (Tabela 6). Na Tabela 6, também se observa que do total de ceras extraída de $V$. westiniana 7,6 \% foram compostos apolares e 92,4 \% compostos polares, apresentando 42,9 $\mu$ g de cera $/ \mathrm{cm}^{2}$. As proporções dos compostos polares e apolares das ceras epicuticulares foram semelhantes nas espécies estudadas do gênero Vernonia. Estas informações sobre as proporções dos compostos polares e apolares destas duas espécies do gênero Vernonia, podem ser de grande utilidade na recomendação de um controle químico, pois poderá dar preferência a herbicidas (associados ou não a surfatantes) que utilizam a rota polar de absorção deste agroquímico. A rota polar referenciada caracteriza-se por compostos que na realidade são compostos menos polares que os chamados apolares, chamados nesta pesquisa de polares.

Tabela 6. Quantidades de ceras epicuticulares presentes em espécies de Vernonia polyanthes (assa-peixe) e Vernonia westiniana (assa-peixe). Piracicaba, SP, 2004 


\begin{tabular}{ccc}
\hline Cera epicuticular $\left(\mu \mathrm{g} / \mathrm{cm}^{2}\right)$ & 31,1 & 42,9 \\
Fração apolar (\%) & 15,0 & 7,6 \\
Fração polar (\%) & 85,0 & 92,4 \\
\hline
\end{tabular}

Nos estudos de MEV sobre as características ultra-estruturais das espécies estudadas da Família Asteraceae foi observado semelhantes características ultra-estruturais, ou seja, ambas apresentaram tricomas glandulares nas duas superfícies foliares, tricomas multicelulares curtos na superfície adaxial e tricomas unicelulares curtos na abaxial (Figuras 3, 4, 5 e 6). Os tricomas glandulares têm cabeça multicelular (duas células) e estão localizados em depressões da superfície foliar (Figuras 3C, 4D, 5C e 6E).

Nestas espécies não foram observados depósitos de ceras epicuticulares (Figuras 3D, 4C, 5DE e 6C), a cera epicuticular estava depositada como uma camada contínua na superfície foliar, ou seja, amorfa (sem forma definida). 

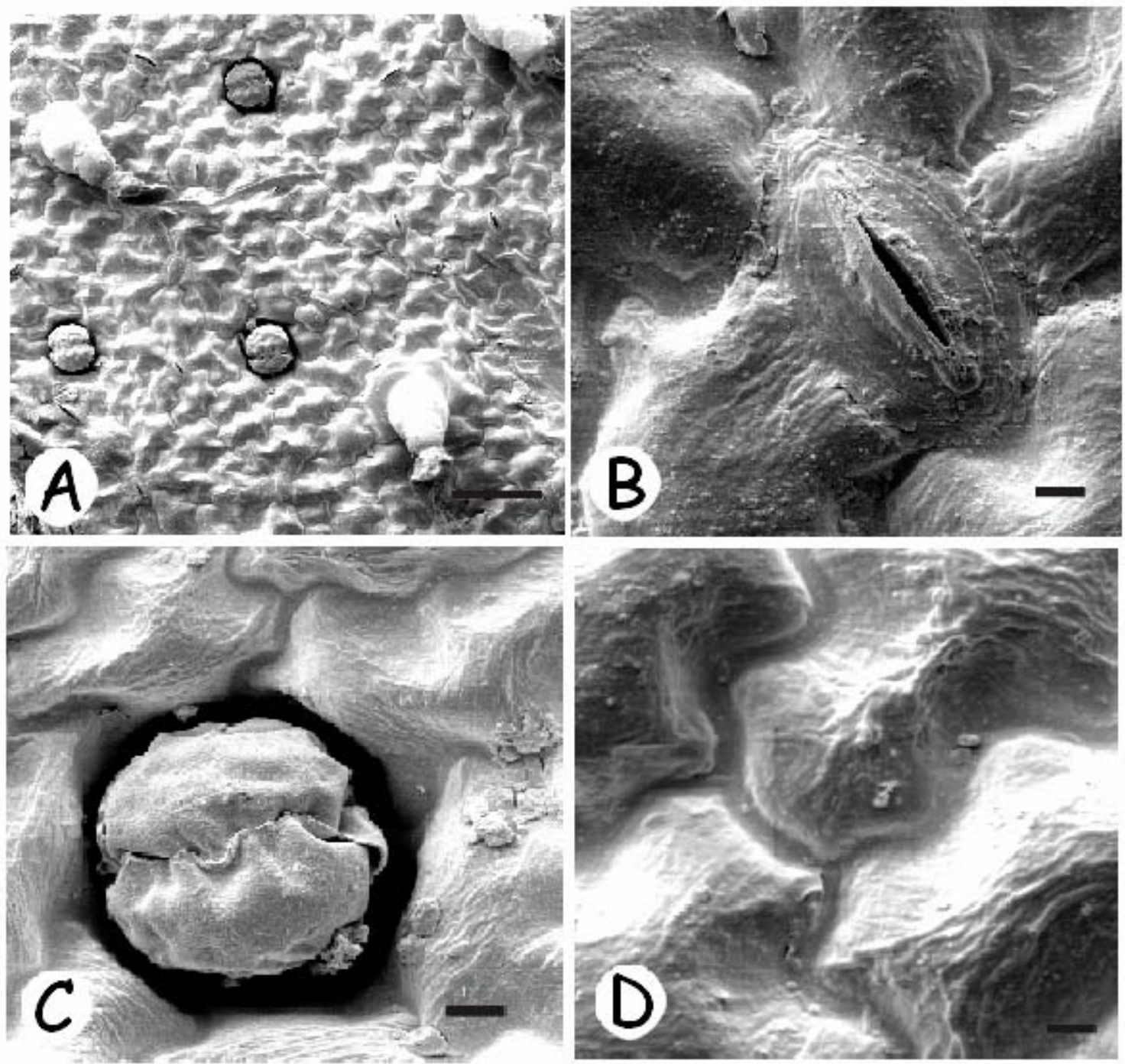

Figura 3 - Superfície foliar adaxial de Vernonia polyanthes (assa-peixe). A: Visão geral da superfície foliar (200x); B: Detalhe do estômato (2000x); C: Detalhe do tricoma glandular (1000x); D: Detalhe da superfície das células epidérmicas (2000x). Barras: $100 \mu \mathrm{m}, 5 \mu \mathrm{m}, 10 \mu \mathrm{m}$ e $5 \mu \mathrm{m}$, respectivamente 


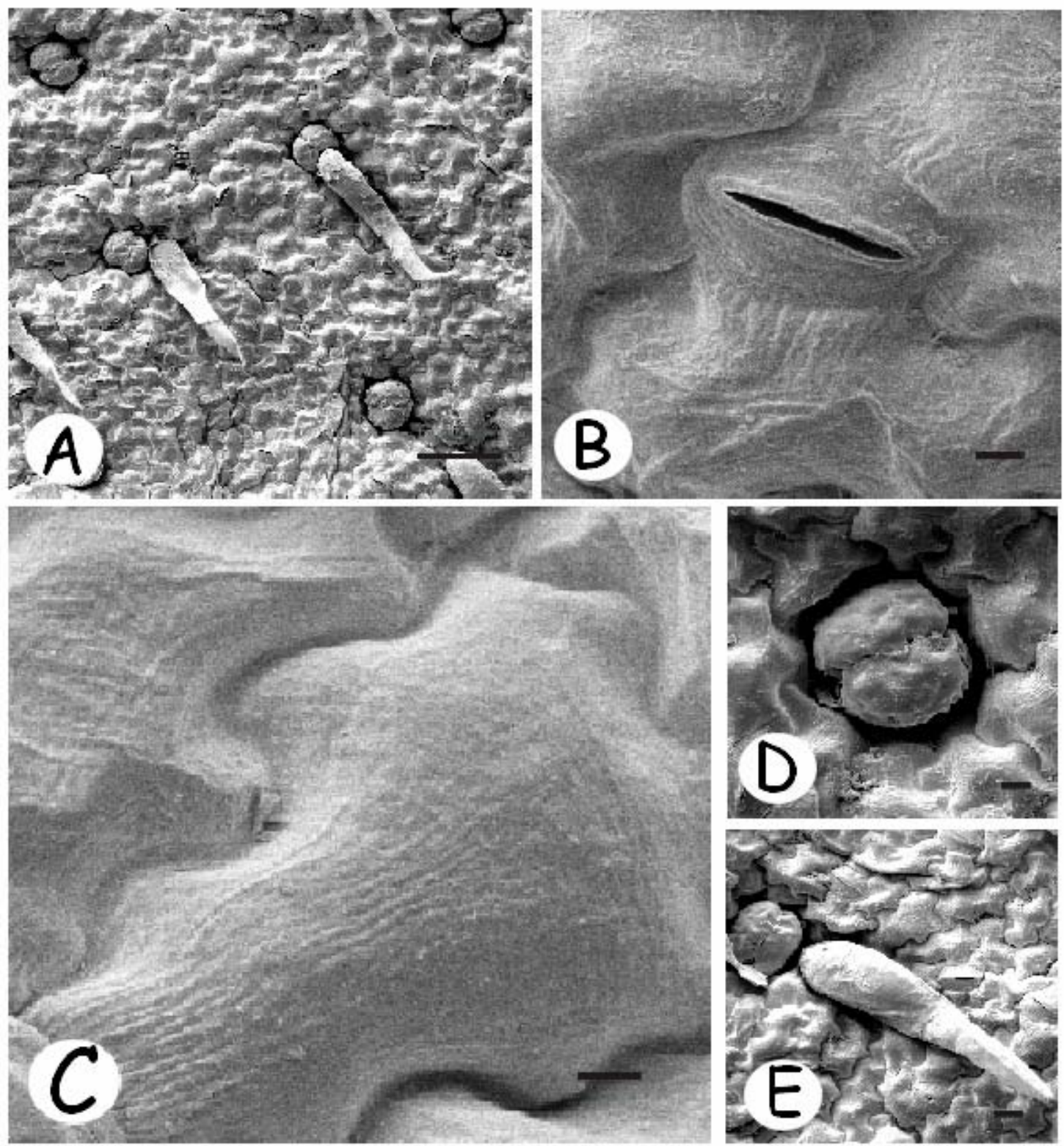

Figura 4 - Superfície foliar abaxial de Vernonia polyanthes (assa-peixe). A: Visão geral da superfície foliar (200x); B: Detalhe do estômato (2000x); C: Detalhe da superfície das células epidérmicas (2000x); D: Detalhe do tricoma glandular (1000x); E: Detalhe do tricoma (500x). Barras: 100 $\mu \mathrm{m}, 5 \mu \mathrm{m}, 5 \mu \mathrm{m}, 10 \mu \mathrm{m}$ e $5 \mu \mathrm{m}$, respectivamente 

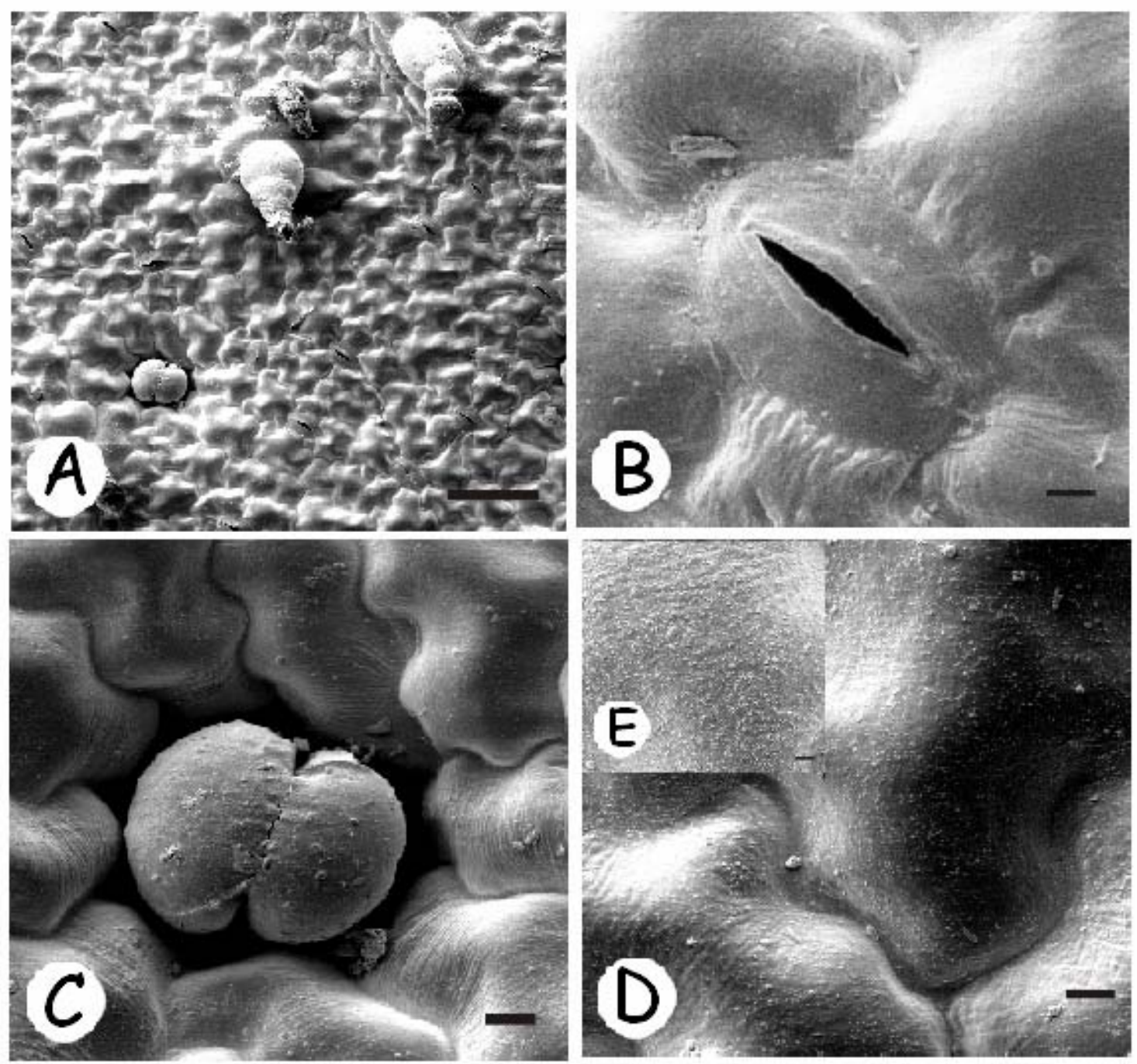

Figura 5 - Superfície foliar adaxial de Vernonia westiniana (assa-peixe). A: Visão geral da superfície foliar (200x); B: Detalhe do estômato (2000x); C: Detalhe do tricoma glandular (1000x); D: Superfície das células epidérmicas (2000x) E: Detalhe da célula epidérmica (5000x). Barras: $100 \mu \mathrm{m}, 5 \mu \mathrm{m}, 10 \mu \mathrm{m}, 5 \mu \mathrm{m}$ e $2 \mu \mathrm{m}$, respectivamente 

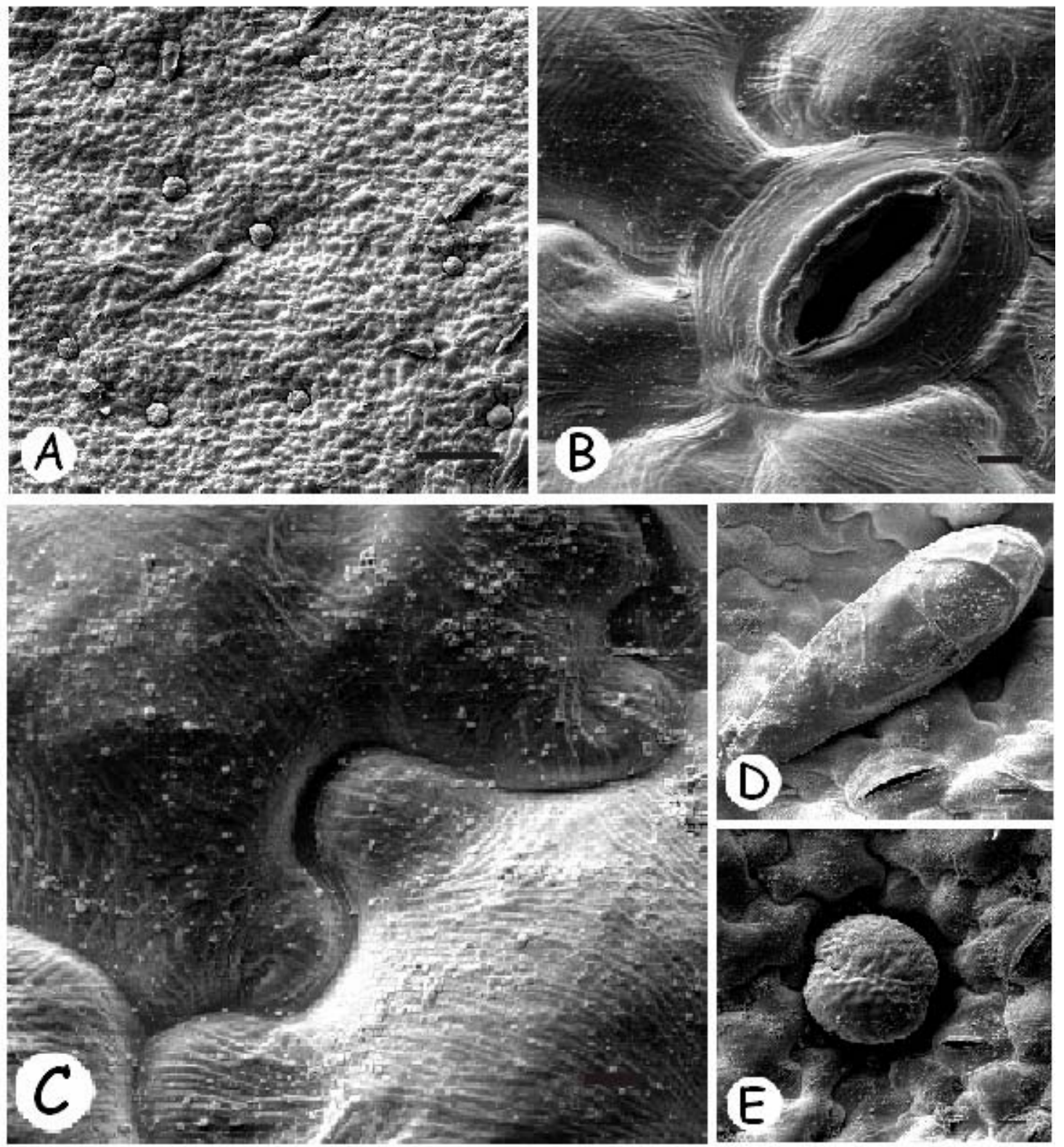

Figura 6 - Superfície foliar abaxial de Vernonia westiniana (assa-peixe). A: Visão geral da superfície foliar (200x); B: Detalhe do estômato (2000x); C: Detalhe da superfície das células epidérmicas (2000x); D: Detalhe do tricoma (1000x); E: Detalhe do tricoma glandular (1000x). Barras: 100 $\mu \mathrm{m}, 5 \mu \mathrm{m}, 5 \mu \mathrm{m}, 10 \mu \mathrm{m}$ e $10 \mu \mathrm{m}$, respectivamente 


\subsection{Conclusões}

Para as condições em que esta pesquisa foi realizada, pôde-se concluir:

a) As espécies $P$. fuchsiaefolia, $V$. polyanthes e $V$. westiniana apresentaram maior densidade estomática na superfície abaxial do que na adaxial.

b) As espécies envolvidas nesta pesquisa ( $P$. fuchsiaefolia, $V$. polyanthes e $V$. westiniana) apresentaram maiores porcentagens de compostos polares.

c) As espécies estudadas não apresentaram cristais de ceras epicuticulares em ambas superfícies foliares, caracterizando-as quanto a estrutura de suas ceras como amorfas. 


\section{CARACTERÍSTICAS DAS SUPERFÍCIES FOLIARES DE PLANTAS DANINHAS. II - BIGNONIACEAE: Memora peregrina e Tecoma stans e CONVOLVULACEAE: Ipomoea grandifolia e Ipomoea purpurea}

\section{Resumo}

Nas folhas, a superfície externa é caracterizada pela presença de epiderme foliar, e presente nesta estão estruturas tais como ceras epicuticulares, estômatos, tricomas e apêndices. A molhabilidade e a penetração do agroquímico depende de muitos fatores, dentre eles o contato da solução pulverizada com os constituintes da cutícula foliar. O objetivo deste trabalho foi avaliar a densidade estomática, a porcentagem de compostos polares e apolares das ceras epicuticulares e observar as características ultra-estruturais da cutícula foliar de Memora peregrina, Tecoma stans, Ipomoea grandifolia e Ipomoea purpurea. A densidade estomática foi determinada em ambas superfícies foliares das espécies vegetais, utilizando a técnica de impressão da epiderme foliar em lâmina de vidro com cola adesiva. Na determinação dos compostos polares e apolares das ceras epicuticulares, as folhas foram imersas em clorofórmio e as amostras foram fracionadas em coluna de sílica gel, onde com o solvente hexano obtevese os compostos apolares e com o clorofórmio, os polares. Para avaliação da quantidade de cera por unidade de área foliar foi determinada a área foliar destas folhas após a imersão em clorofórmio. A análise ultra-estrutural de superfícies foliares foi realizada observando imagens obtidas com a Microscopia Eletrônica de Varredura. A espécie $M$. peregrina apresentou 368,0 estômatos $/ \mathrm{mm}^{2}$ de área foliar da superfície abaxial e foram ausentes na superfície adaxial. Enquanto que a espécie T. stans apresentou 9,7 estômatos $/ \mathrm{mm}^{2}$ na adaxial e 78,2 na abaxial. As espécies da Família Bignoniaceae apresentaram 
porcentagens de compostos polares e apolares semelhantes nas ceras epicuticulares. A densidade estomática da espécie I. grandifolia foi 44,0 estômatos $/ \mathrm{mm}^{2}$ na adaxial e 156,0 na abaxial, e na espécie I. purpurea foi 62,8 estômatos $/ \mathrm{mm}^{2}$ e 131,2 na abaxial. As espécies do gênero Ipomoea apresentaram maior quantidade de compostos polares. As superfícies foliares de I. grandifolia e I. purpurea apresentaram tricomas unicelulares e ceras epicuticulares na forma de estrias nas superfícies adaxiais.

\section{FOLIAR SURFACES CHARACTERISTICS OF WEEDS. II - BIGNONIACEAE: Memora peregrina and Tecoma stans and CONVOLVULACEAE: Ipomoea grandifolia and Ipomoea purpurea}

\section{Summary}

In the leaves, the external surface is characterized by presence of epidermis and this surface contains epicuticular waxes, stomatas, trichomes and appendixes. The wettability and the penetration of the pesticide depend on many factors, like the contact of the solution sprayed with the foliar cuticle. The objective of this research was to evaluate the stomatal density, the polar and apolar compounds percentage of the epicuticular waxes and to analyze the ultra-structural of the cuticle of Memora peregrina, Tecoma stans, Ipomoea grandifolia and Ipomoea purpurea. The number stomata for unit of foliar area (stomatal density) was determined in both foliar surfaces of the plants, with the impression of the foliar epidermis in sheet of glass using glue. In the determination of the polar and apolar compounds of the epicuticular waxes, the leaves were dipped in chloroform and the samples were divided using a column of silica gel, where the solvent hexane extracted the apolar compounds and the chloroform extracted the polar compounds from this column. The leaves were dipped in chloroform to extract the epicuticular wax and after were determined foliar area. The ultra-structural analyses of the foliar surfaces were determined observing images obtained with Scanning Electronic Microscopy. In the foliar surface of M. peregrina there were 368.0 stomatas $/ \mathrm{mm}^{2}$ on foliar area of the abaxial surface and on the adaxial surface there were 
not stomatas. The foliar surface of $T$. stans had 9.7 stomatas $/ \mathrm{mm}^{2}$ in the adaxial surface and 78.2 in the abaxial. The percentages of polar and apolar compounds in the epicuticular waxes in Family Bignoniaceae's species were similar. The stomatal density of the specie I. grandifolia was 44.0 stomatas $/ \mathrm{mm}^{2}$ in the adaxial surface and 156.0 in the abaxial. In the foliar surface of I. purpurea had 62.8 stomatas $/ \mathrm{mm}^{2}$ and 131.2 in the abaxial. The species of the Ipomoea genus presented great amount of polar compounds. In the adaxial surfaces of I. grandifolia and I. purpurea there were unicellular trichomes and epicuticular waxes in form of ridge.

\subsection{Introdução}

Nas folhas localizam-se várias estruturas funcionais, como as ceras e os estômatos, os tricomas, os apêndices, os tricomas glandulares, entre outras. A presença ou ausência dessas estruturas funcionais nas folhas influenciará a entrada do herbicida através da cutícula. As superfícies foliares de plantas daninhas são os alvos que o herbicida veiculado na calda de pulverização deve atingir. O conhecimento das características das superfícies foliares determina a utilização mais adequada do herbicida e conseqüentemente sua eficácia no controle.

As plantas daninhas estudadas são da Classe Dicotiledônea e também conhecidas por plantas daninhas de folhas largas. Na Tabela 7 estão apresentadas informações quanto à família, nome científico, nomes comuns e código internacional de cada espécie. 
Tabela 7. Famílias, espécies, nomes comuns e códigos internacionais das espécies de plantas daninhas dicotiledôneas

\begin{tabular}{cllc}
\hline Família & \multicolumn{1}{c}{ Nome Científico } & \multicolumn{1}{c}{ Nome Comum } & Cód. Int. \\
\hline Bignoniaceae & $\begin{array}{l}\text { Memora peregrina (Miers) } \\
\text { Sandwith }\end{array}$ & Cipó-arame, ciganinha & Inexistente \\
& Tecoma stans (L.) Juss. ex Kunth & Amarelinho, guarã-guarã, ipê- & \\
& & amarelo-de-jardim, ipê-de-jardim, & \\
& & TECST \\
Convolvinho-de-jardim, sinos amarelos & \\
& & Campainha, corda-de-viola, corriola & IAOGR \\
& Ipomoea grandifolia (Dammer) & & \\
& O’Donell & campainha, corda-de-viola, corriola, & PHBPU \\
& Ipomoea purpurea (L.) Roth. & bom-dia, jitirana, glória-da-manhã & \\
\hline
\end{tabular}

Fonte: Lorenzi (2000).

A espécie Memora peregrina (Miers) Sandwith é uma planta perene, ereta de ramos escandentes, lenhosas, pouca ramificada, com folhas de textura coriácea e áspera, de 80-140 cm de altura, nativa do Brasil. Propaga-se por sementes, contudo expande-se numa grande reboleira através de rizomas. É uma planta típica dos cerrados brasileiros que perpetua-se nestas áreas após a sua transformação em pastagens, tornando-se uma planta indesejável. Formam grandes reboleiras de difícil controle e ou erradicação. A espécie Tecoma stans (L.) Juss. ex Kunth é uma planta arbustiva ou pequena árvore de até $7 \mathrm{~m}$ de altura, ramificada, glabra, com casca quase lisa de cor pardo esverdeada, originária da América Central. Propaga-se com grande intensidade através de sementes. Planta muito cultivada como ornamental em todo o país, onde escapou para tornar-se uma séria planta daninha de pastagens e de terrenos baldios (Lorenzi, 2000).

Lorenzi (2000) e Kissmann \& Groth (1999) descrevem as espécies estudadas da família Convolvulaceae como sendo a espécie Ipomoea grandifolia (Dammer) O’Donell uma planta anual, trepadeira, volúvel, herbácea, de caules com leve pilosidade translúcida, de 1-2 m de comprimento, propaga-se por sementes. É uma das plantas daninhas mais prejudiciais nas culturas anuais e perenes de verão das regiões Centro-Oeste, Sudeste e Sul do país. A espécie Ipomoea purpurea (L.) Roth. é uma planta 
anual, trepadeira, herbácea, de caules com pilosidade brancacenta e estrelada, ramificada, com 1-3 m de comprimento, propaga-se por sementes e é originária da América Tropical e Subtropical com ocorrência em todo o território brasileiro. É uma das mais sérias infestantes de lavouras anuais existentes no país.

Nunes (1999) alerta que a infestação da ciganinha (Memora peregrina) já inviabilizou várias áreas de pastagens ou mesmo propriedades, por causa dos altos níveis de infestação e elevados custos para erradicá-la. Ainda destaca, que esta alta capacidade de infestação deve-se a eficientes formas de dispersão e propagação vegetativa, além das sementes aladas, possuem caules subterrâneos com grande capacidade de rebrote. A recomendação deste autor quanto ao controle da ciganinha (Memora peregrina) é que seja de modo amplo, ou seja, envolvendo toda uma região de forma integrada, incluindo medidas preventivas, métodos químicos e mecânicos associados, aliados a práticas culturais e de manejo que favoreçam o desenvolvimento da forrageira desejada.

Características da superfície foliar como a topografia celular, grau e tipo de desenvolvimento de ceras epicuticulares, tricomas e glândulas influenciam o depósito de herbicidas na superfície foliar (Hess \& Falk, 1990).

A cutícula é constituída de cutina, ceras epicuticulares, ceras cuticulares e pectina, variando sua espessura de 0,1 a $10 \mu \mathrm{m}$ entre as espécies vegetais. A ordem crescente de lipofilicidade da cutícula é pectina<cutina<cera (Hess, 1997).

Segundo Kirkwood (1999), as propriedades físico-químicas da cutícula influenciam o comportamento da gota de pulverização, podendo afetar a taxa e eficiência da penetração cuticular.

As ceras epicuticulares podem ser encontradas na forma de placas, tubos, fitas, vara, filamentos e dentritos (Baker, 1991). O tipo de estrutura de cera influencia a capacidade de molhamento da solução de pulverização. Geralmente, a superfície foliar lisa, isenta de cristais de ceras epicuticulares, porém com ceras amorfas que são relativamente fácil de molhar, como as encontradas em muitas espécies de dicotiledôneas. Superfícies foliares cobertas com cristais de ceras epicuticulares são muito mais difíceis para molhar, como em muitas espécies de monocotiledôneas (Hess, 1997). 
Harr et al. (1991) e Mendonça (2000a) determinaram a porcentagem de compostos polares e apolares das ceras epicuticulares de diversas plantas daninhas, por meio de extração com clorofórmio e posterior separação em coluna de sílica gel com diferentes eluentes (hexano e clorfórmio). Mendonça (2000a) observou que a cera epicuticular da espécie Commelina benghalensis apresentou maior quantidade de compostos apolares e de Digitaria insularis a menor quantidade. Comparando os resultados das espécies estudadas em ambos trabalhos, C. rotundus apresentou resultados discordantes com relação aos compostos polares e apolares.

Os fatores que influenciam na quantidade e distribuição de herbicidas na superfície foliar, afetando a absorção são: a tensão superficial da solução de pulverização, a quantidade de cera cuticular e estrutura física das ceras e dos tricomas da superfície foliar, a orientação das folhas e a área foliar por planta (Hess, 1997).

Os produtos fitossanitários geralmente devem ser depositados nas superfícies de folhas, ramos e frutos e, para uma boa compatibilidade física entre essas superfícies e as caldas de pulverização, deve-se levar em consideração a espécie da planta, a idade dos órgãos e as condições ambientais (Kissmann, 1997).

O objetivo desta pesquisa foi estudar as características ultra-estruturais de superfícies foliares das seguintes plantas daninhas: Memora peregrina (Miers) Sandwith e Tecoma stans (L.) Juss. ex Kunth, Ipomoea grandifolia (Dammer) O’Donell e Ipomoea purpurea (L.) Roth., pela determinação da densidade estomática, pela caracterização das ceras epicuticulares determinando sua massa e a porcentagem de compostos polares e apolares e utilizando a microscopia eletrônica de varredura para observar a superfície foliar.

\subsection{Material e Métodos}

As plantas foram cultivadas em condições de casa-de-vegetação do Departamento de Produção Vegetal da ESALQ/USP, com temperatura variando de 15 a 35 ${ }^{\circ} \mathrm{C}$, com turno de irrigação diário. O solo utilizado para o cultivo das plantas daninhas apresentava as seguintes características físicas: 64\% de areia total, 26 \% de argila e $10 \%$ 
de silte, classificado como textura média argilosa. As características químicas do solo utilizado estão apresentadas na Tabela 8. As plantas daninhas avaliadas encontravam-se com aproximadamente $30 \mathrm{~cm}$ de altura.

Tabela 8. Características químicas do solo (macronutrientes e micronutrientes). Piracicaba, SP, 2004

\begin{tabular}{|c|c|c|c|c|c|c|c|c|c|c|c|c|c|c|}
\hline $\mathrm{pH}$ & M. O. & B & $\mathrm{Cu}$ & $\mathrm{Fe}$ & Mn & $\mathrm{Zn}$ & $\mathrm{P}_{\text {resina }}$ & $\mathrm{H}+\mathrm{Al}$ & $\mathrm{K}$ & $\mathrm{Ca}$ & $\mathrm{Mg}$ & SB & СТC & V\% \\
\hline $\mathrm{CaCl}_{2}$ & g.dm ${ }^{-3}$ & $\ldots$ & & & $\mathrm{dm}^{-3}$. & & $\cdots$ & & & & c. $\mathrm{dm}$ & & & \\
\hline 5,4 & 11 & 0,14 & 0,6 & 4 & 3,4 & 0,8 & 4 & 12 & 0,1 & 31 & 25 & 56,1 & 68,1 & 82 \\
\hline
\end{tabular}

\subsubsection{Densidade estomática}

O número de estômatos por unidade de área de epiderme foliar (densidade estomática) foi determinado nas superfícies adaxial e abaxial das folhas das plantas daninhas. Utilizou-se a técnica de impressão de epiderme em adesivo a base de éster de cianoacrilato (Mendonça, 2000a). Para tanto, uma gota do adesivo foi depositada em lâmina de vidro para microscopia, colocando a folha com a superfície desejada voltada para a cola pressionando-a na lâmina. Após secagem do adesivo, o material vegetal foi retirado, permanecendo a impressão da epiderme na lâmina. A densidade estomática foi determinada em microscópio ótico de luz (Marca Carl Zeiss, Modelo Axio Skop 2), acoplado ao computador com o software Axiovision. Nas avaliações da densidade estomática das superfícies foliares foram utilizadas 50 repetições. Os dados foram analisados estatisticamente pelo valor de t $(\mathrm{P}>0,05)$, determinando os intervalos de confiança mínimo e máximo. Também foi analisado o nível de significância em que as médias das superfícies foliares (adaxial e abaxial) foram diferentes, pelo Teste t entre as duas superfícies, utilizando o software Excel.

\subsubsection{Separação dos compostos polares e apolares}


Os compostos polares e apolares das ceras epicuticulares foram separados segundo metodologia utilizada por Mendonça (2000a). As ceras foram extraídas mergulhando as folhas em clorofórmio por 30 segundos, tomando-se o cuidado para não expor o corte ao solvente, determinou-se a área foliar das folhas para determinação da quantidade de $\mu$ g de cera/ $\mathrm{cm}^{2}$. A amostra foi filtrada em papel de filtro e o solvente foi evaporado. Para as determinações de ceras totais as alíquotas foram transferidas para vials de $4 \mathrm{~mL}$, secas totalmente e pesadas em balança com precisão de 0,0001 g. Para o fracionamento de compostos polares e apolares a cera foi redissolvida em $0,5 \mathrm{~mL}$ de clorofórmio, colocada em coluna empacotada de sílica gel (SiOH). Esta coluna foi mantida a vácuo para total secagem do solvente e em seguida foi realizada a seguinte sequência de solventes: $20 \mathrm{~mL}$ de hexano e $20 \mathrm{~mL}$ de clorofórmio, sendo estes solventes coletados separadamente. Foram obtidas duas frações da amostra, onde a fração extraída pelo hexano correspondeu a apolar e a extraída pelo clorofórmio a menos apolar, chamada de "polar". Os solventes foram evaporados e pesados em balança de precisão de 0,0001g.

\subsubsection{Análise ultra-estrutural da epiderme foliar}

Os estudos ultra-estruturais da epiderme foliar foram realizados através de Microscopia Eletrônica de Varredura (MEV), caracterizando as faces adaxial e abaxial da região mediana da lâmina foliar das espécies de plantas daninhas e foram conduzidos no Núcleo de Apoio à Pesquisa/ Microscopia Eletrônica Aplicada à Pesquisa Agropecuária (NAP/MEPA), da ESALQ/USP.

Protocolo de preparo de amostra para observação em microscópio eletrônico de varredura (Kitajima \& Leite, 1999): amostras foliares com dimensões aproximadas de 2x2 mm, foram fixadas em solução de fixador "Karnovsky" (glutaraldeído 2,5 \%, formaldeído 2,5 \% em tampão cacodilato de sódio 0,05 M, pH 7,2, $\mathrm{CaCl}_{2}$ 0,001 M), por uma hora. Em seguida, as amostras foram lavadas em tampão cacodilato 0,05 M por três vezes e pós-fixadas em tetraóxido de ósmio $1 \%$ em tampão cacodilato 0,05 M, pH 7,2 por uma hora em temperatura ambiente. As amostras fixadas no tetraóxido de ósmio foram 
lavadas com água destilada e desidratadas por uma série de concentração crescente de acetona (30, 50, 70 e 90 \%) uma vez cada por 10 minutos e em 100 \% de acetona por três vezes de 10 minutos. Nas amostras realizou-se a secagem ao ponto crítico com a finalidade de retirar a acetona das amostras foliares, substituindo-a por $\mathrm{CO}_{2}$ líquido, em seguida mudando seu estado físico para gasoso (Marca Balzers e Modelo CPD 050). Em seguida as amostras foram metalizadas com ouro (Marca Balzers e Modelo MED 010).

Os materiais foram observados ao Microscópio Eletrônico de Varredura da Marca Zeiss e do Modelo DSM900. As imagens selecionadas nas observações ao microscópio eletrônico de varredura foram trabalhadas no software Corel Photo-Paint 9.0 para montagem das figuras.

\subsection{Resultados e Discussão}

\subsubsection{Bignoniaceae: $\underline{\text { Memora peregrina e Tecoma stans }}$}

Na Tabela 9 estão apresentados os resultados de densidade estomática das espécies da Família Bignoniaceae avaliadas. Observou-se a ausência de estômatos na superfície adaxial de $M$. peregrina, porém grande quantidade na superfície abaxial e maior densidade estomática obtida dentre as espécies estudadas. Em T. stans observouse uma reduzida densidade estomática na superfície adaxial em comparação com superfície abaxial, através da análise estatística dos dados pode-se afirmar que as densidades estomáticas foram diferentes nas superfícies foliares, com uma probabilidade de serem iguais de 1,74E-46.

Tabela 9. Densidade estomática de Memora peregrina (ciganinha) e Tecoma stans (amarelinho). Piracicaba, SP, 2004 


\begin{tabular}{|c|c|c|c|c|}
\hline & \multicolumn{4}{|c|}{ Densidade estomática (estômatos/mm²) } \\
\hline & \multicolumn{2}{|c|}{ M. peregrina } & \multicolumn{2}{|c|}{ T. stans } \\
\hline & adaxial & abaxial & adaxial & abaxial \\
\hline Média & 0 & 368,0 & 9,7 & 78,2 \\
\hline IC mínimo ${ }^{1}$ & 0 & 363,6 & 2,8 & 74,3 \\
\hline IC máximo ${ }^{1}$ & 0 & 399,3 & 12,5 & 82,0 \\
\hline $\mathrm{P}(\mathrm{T}<=\mathrm{t})^{2}$ & \multicolumn{2}{|c|}{$3,25 \mathrm{E}-28$} & \multicolumn{2}{|c|}{$1,74 \mathrm{E}-46$} \\
\hline Correlação & --- & $-0,12$ & --- & $-0,12$ \\
\hline
\end{tabular}

\footnotetext{
${ }^{1}$ IC: intervalo de confiança (t à 5\% de probabilidade).

${ }^{2}$ Teste t: duas amostras presumindo variâncias diferentes.
}

Os estômatos encontrados em ambas espécies foram classificados quanto à forma como paracíticos (Mauseth, 1988), onde as células guardas estão rodeadas por duas células subsidiárias, dispostas paralelamente às células guardas.

A ciganinha ( $M$. peregrina) é uma planta infestante de pastagem e o seu controle vem sendo considerado difícil. A grande quantidade de estômatos encontrados por área foliar na superfície abaxial e a ausência na superfície adaxial, podendo esta característica ser considerada uma provável estratégia desta espécie (ciganinha) como planta daninha. Pois a entrada do herbicida por essa rota (via estomatal) na superfície adaxial seria improvável, reduzindo assim algumas opções para melhorar o controle, por exemplo, com a utilização de certos surfatantes que reduzem tensão superficial para permitindo a absorção pelo estômato.

Foram observadas semelhantes proporções entre os compostos polares e apolares das ceras epicuticulares das espécies $M$. peregrina e T. stans (Tabela 10). Na espécie $M$. peregrina foi encontrada $41,5 \%$ de compostos apolares e 58,5 \% de compostos polares do total de cera extraída, com 22,8 $\mu$ g de cera $/ \mathrm{cm}^{2}$. E nas análises de ceras epicuticulares da espécie T.stans, observou-se 16,82 $\mu$ g de cera/ $\mathrm{cm}^{2}$, dividindo-se em 40,5 \% de compostos apolares e 59,5 \% em polares. Concluindo que esta foi uma característica da família Bignoniaceae. 
Tabela 10. Quantidade de ceras epicuticulares presentes nas espécies de Memora peregrina (ciganinha) e Tecoma stans (amarelinho). Piracicaba, SP, 2004

\begin{tabular}{ccc}
\hline Parâmetro & M. peregrina & T. stans \\
\hline Cera epicuticular $\left(\mu \mathrm{g} / \mathrm{cm}^{2}\right)$ & 22,8 & 16,8 \\
Fração apolar (\%) & 41,5 & 40,5 \\
Fração polar (\%) & 58,5 & 59,5 \\
\hline
\end{tabular}

Nas análises ultra-estruturais através de microscopia eletrônica de varredura da espécie $M$. peregrina amostrou-se folhas velhas (Figuras 7 e 8) e folhas jovens (Figuras 9 e 10) provenientes da mesma planta. Este tipo de amostragem foi escolhido por suas diferenças no aspecto visual, onde as velhas apresentaram-se como coriáceas de cor verde-musgo e as jovens mais tenras de cor verde claro. A diferença mais importante sob o aspecto idade foi o depósito de ceras, em folhas velhas estes depósitos foram espessos e distribuídos pelas duas superfícies foliares (Figuras 7, 8E e 8F). Na superfície abaxial de folhas velhas estes depósitos chegaram até cobrir os estômatos (Figura 8C). Quando jovens a superfície adaxial de folhas de $M$. peregrina apresentaram tricomas glandulares, superfície sem depósitos de cera e tricomas simples sobre a nervura (Figura 9). Em ambas fases de desenvolvimento, foi observada outra forma de tricoma glandular na superfície abaxial (Figuras 8B e 10B). As superfícies abaxiais das folhas velhas e das folhas jovens apresentaram estômatos de tamanho pequeno (Figuras 8C e 10C), estando estes ausentes nas superfícies adaxiais (Figuras 7A e 9A). Com estes estudos concluiu-se que os ricos depósitos de cera epicuticular somamse as possíveis características ultra-estruturais que dificultam o controle desta planta daninha.

Na espécie T. stans foi observada em ambas superfícies foliares tricomas glandulares (Figuras 11C e 12C) e superfície foliar com depósitos de ceras amorfos (Figuras 11D e 12D). Porém na superfície adaxial os tricomas e os estômatos estavam em menores densidades do que na superfície abaxial (Figuras 11 e 12). 


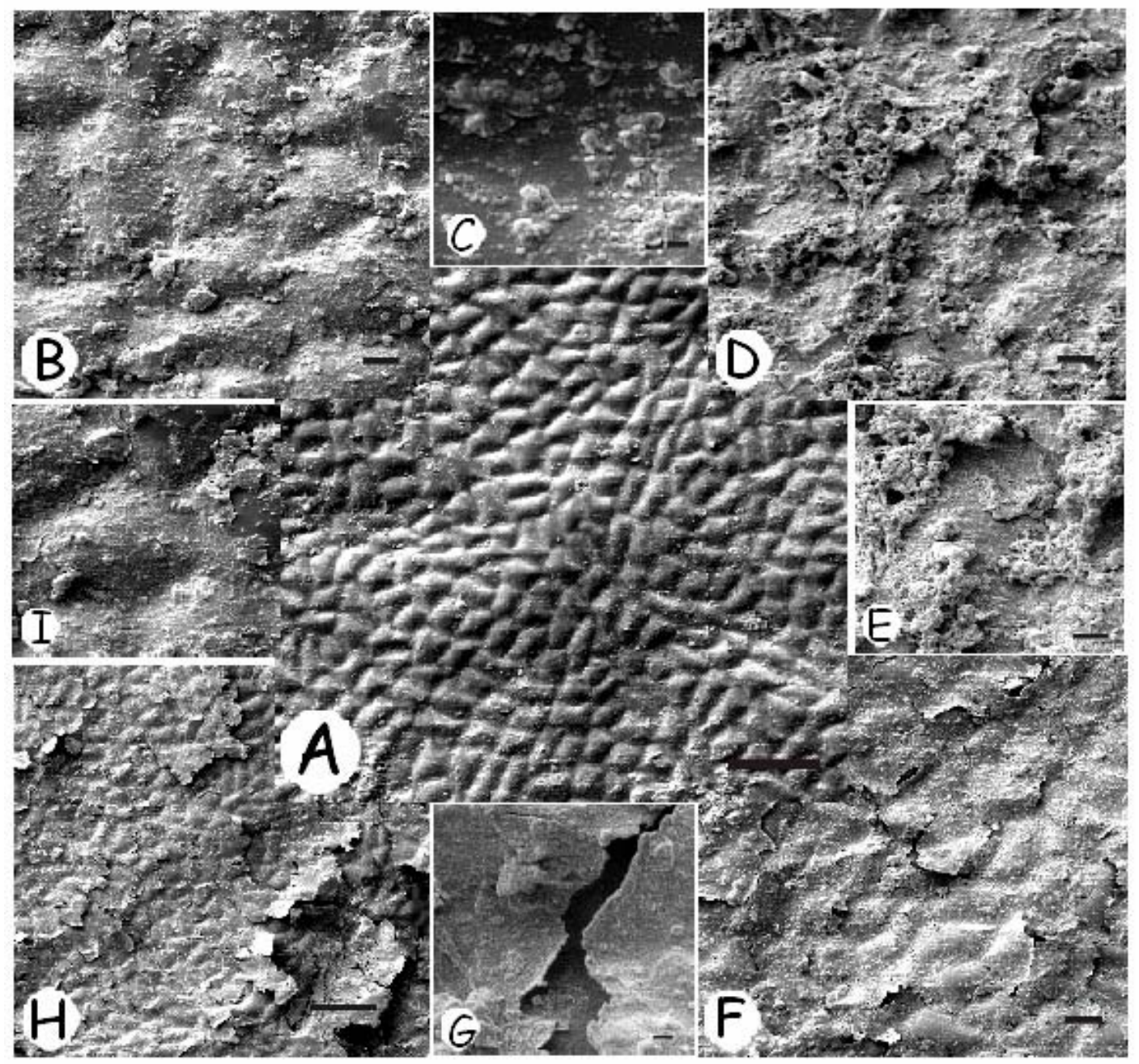

Figura 7 - Superfície adaxial de folhas velhas de Memora peregrina (ciganinha). A: Visão geral da superfície foliar (200x); B (1000x), C (5000x), D (1000x), E (3000x), F (500x), G (5000x), H (200x) e I (2000x): Detalhes de cera epicuticular. Barras: $100 \mu \mathrm{m}, 10 \mu \mathrm{m}, 2 \mu \mathrm{m}, 10 \mu \mathrm{m}, 5 \mu \mathrm{m}, 20 \mu \mathrm{m}, 100 \mu \mathrm{m}$ e $5 \mu \mathrm{m}$, respectivamente 


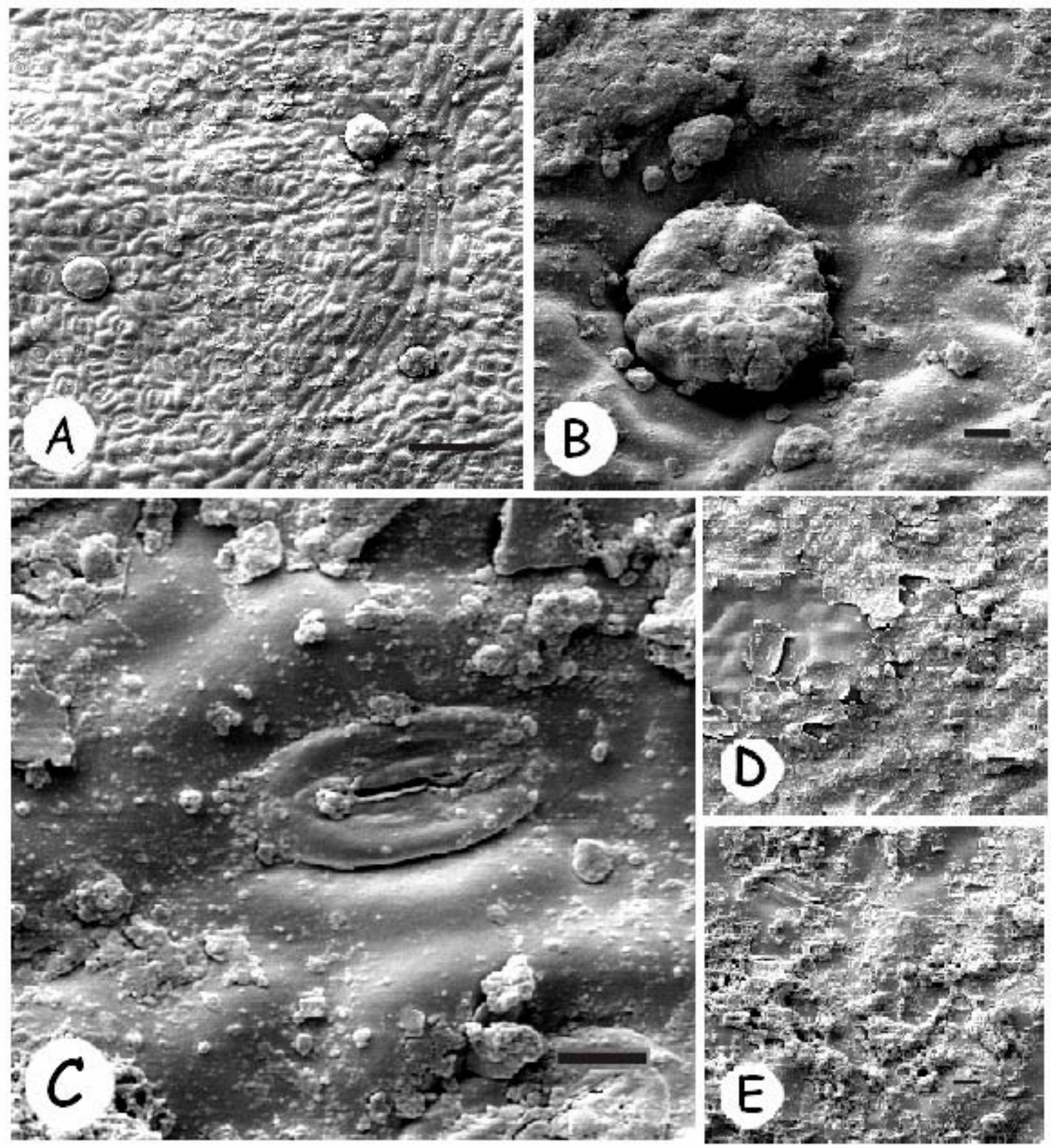

Figura 8 - Superfície abaxial de folhas velhas de Memora peregrina (ciganinha). A: Visão geral da superfície foliar (200x); B: Detalhe do tricoma glandular (1000x); C: Detalhe do estômato (3000x); D: Cera epicuticular (1000x); E: Detalhe da cera epicuticular (2000x). Barras: $100 \mu \mathrm{m}, 10 \mu \mathrm{m}, 5 \mu \mathrm{m}, 10 \mu \mathrm{m}$ e $5 \mu \mathrm{m}$, respectivamente 

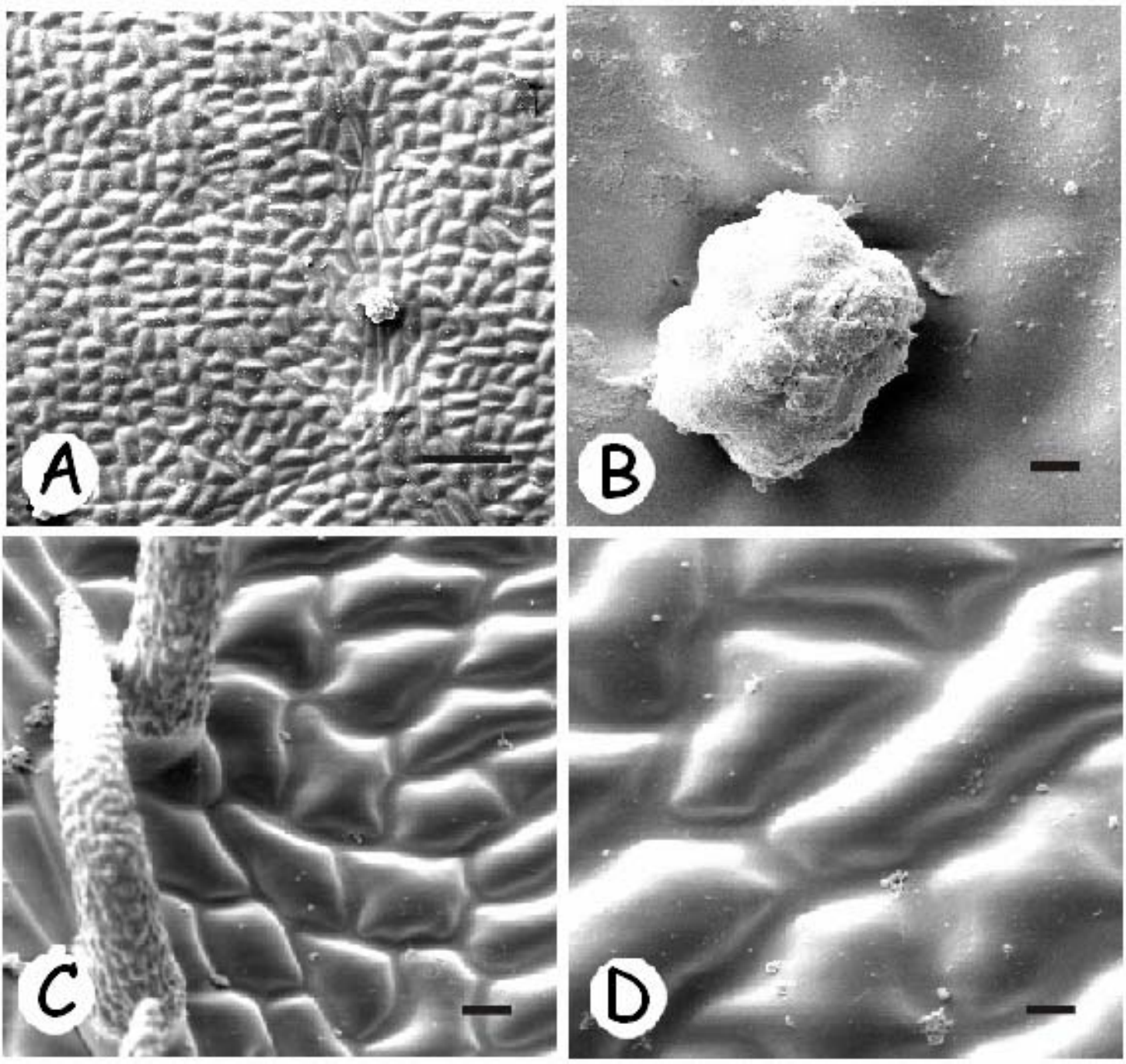

Figura 9 - Superfície adaxial de folhas novas de Memora peregrina (ciganinha). A: Visão geral da superfície foliar (200x); B: Detalhe do tricoma (2000x); C: Detalhe da nervura (1000x); D: Detalhe das células epidérmicas (2000x). Barras: $100 \mu \mathrm{m}, 5 \mu \mathrm{m}, 10 \mu \mathrm{m}$ e $5 \mu \mathrm{m}$, respectivamente 

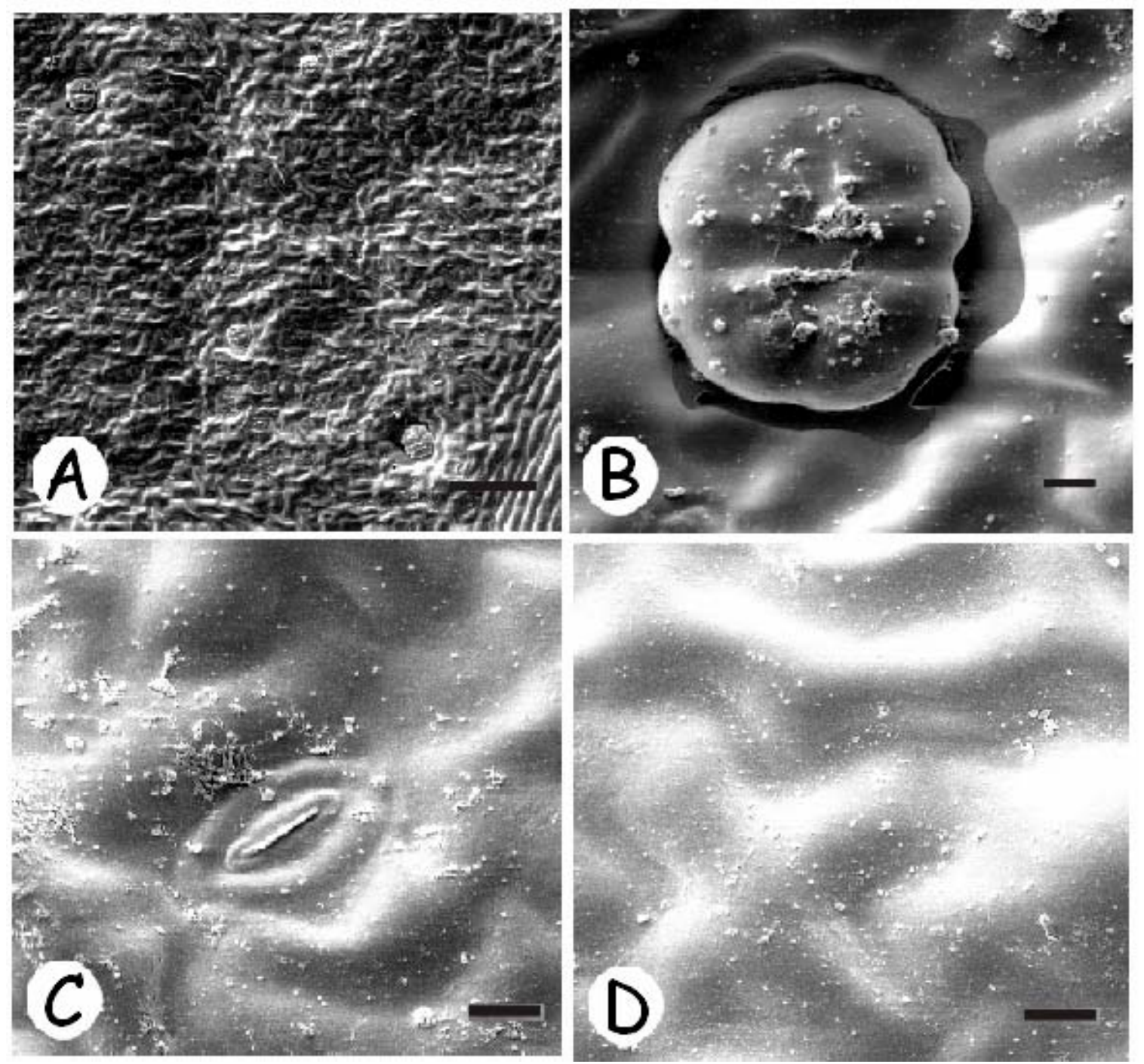

Figura 10 - Superfície abaxial de folhas novas de Memora peregrina (ciganinha). A: Visão geral da superfície foliar (200x); B: Detalhe do tricoma (2000x); C:

Detalhe do estômato (3000x); D: Detalhe das células epidérmicas (2000x).

Barras: $100 \mu \mathrm{m}, 5 \mu \mathrm{m}, 5 \mu \mathrm{m}$ e $5 \mu \mathrm{m}$, respectivamente 

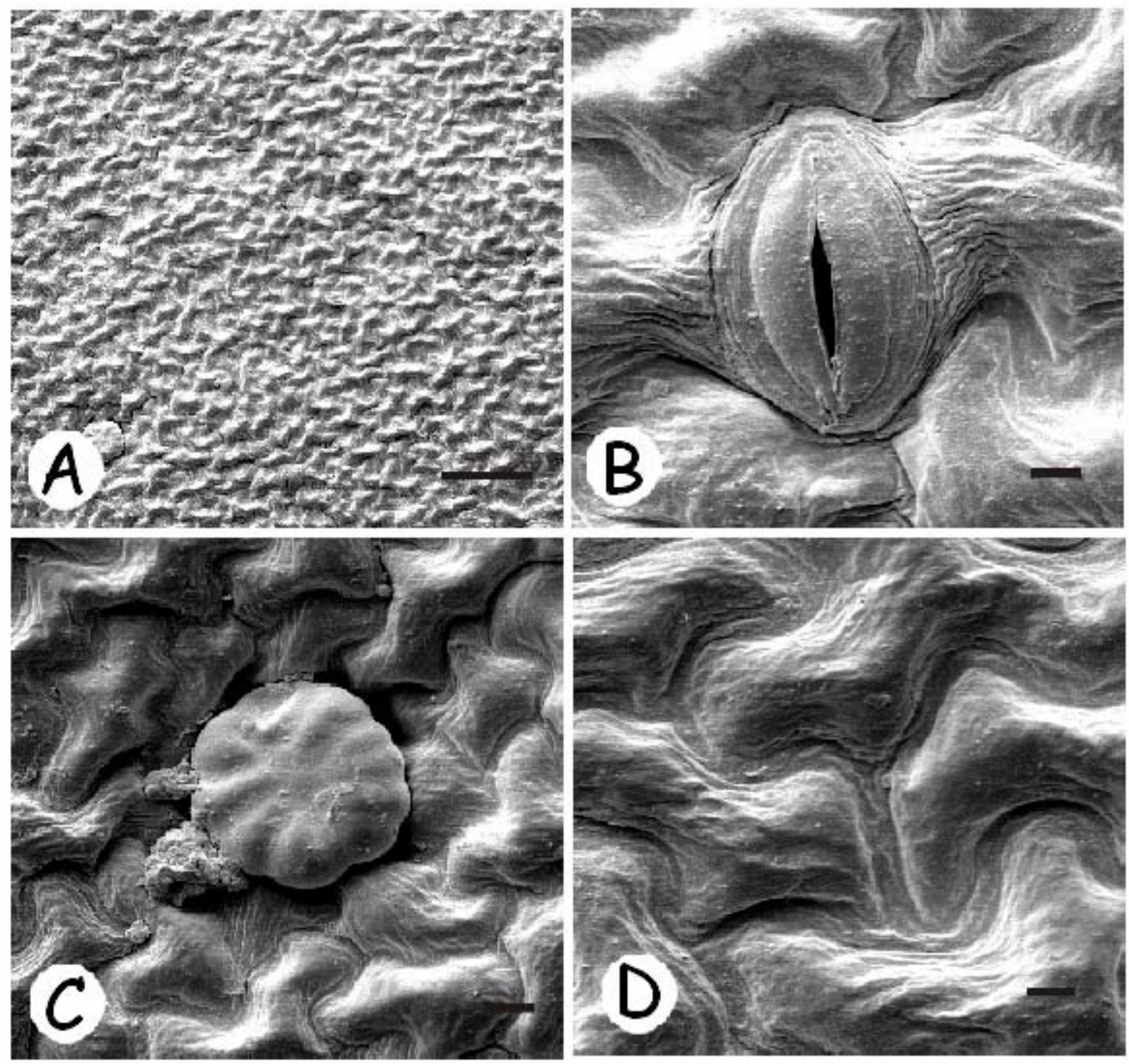

Figura 11 - Superfície foliar adaxial de Tecoma stans (amarelinho). A: Visão geral da superfície foliar (200x); B: Detalhe do estômato (2000x); C: Detalhe de tricoma glandular (1000x); D: Células epidérmicas (2000x). Barras: 100 $\mu \mathrm{m}, 5 \mu \mathrm{m}, 10 \mu \mathrm{m}$ e $5 \mu \mathrm{m}$, respectivamente 

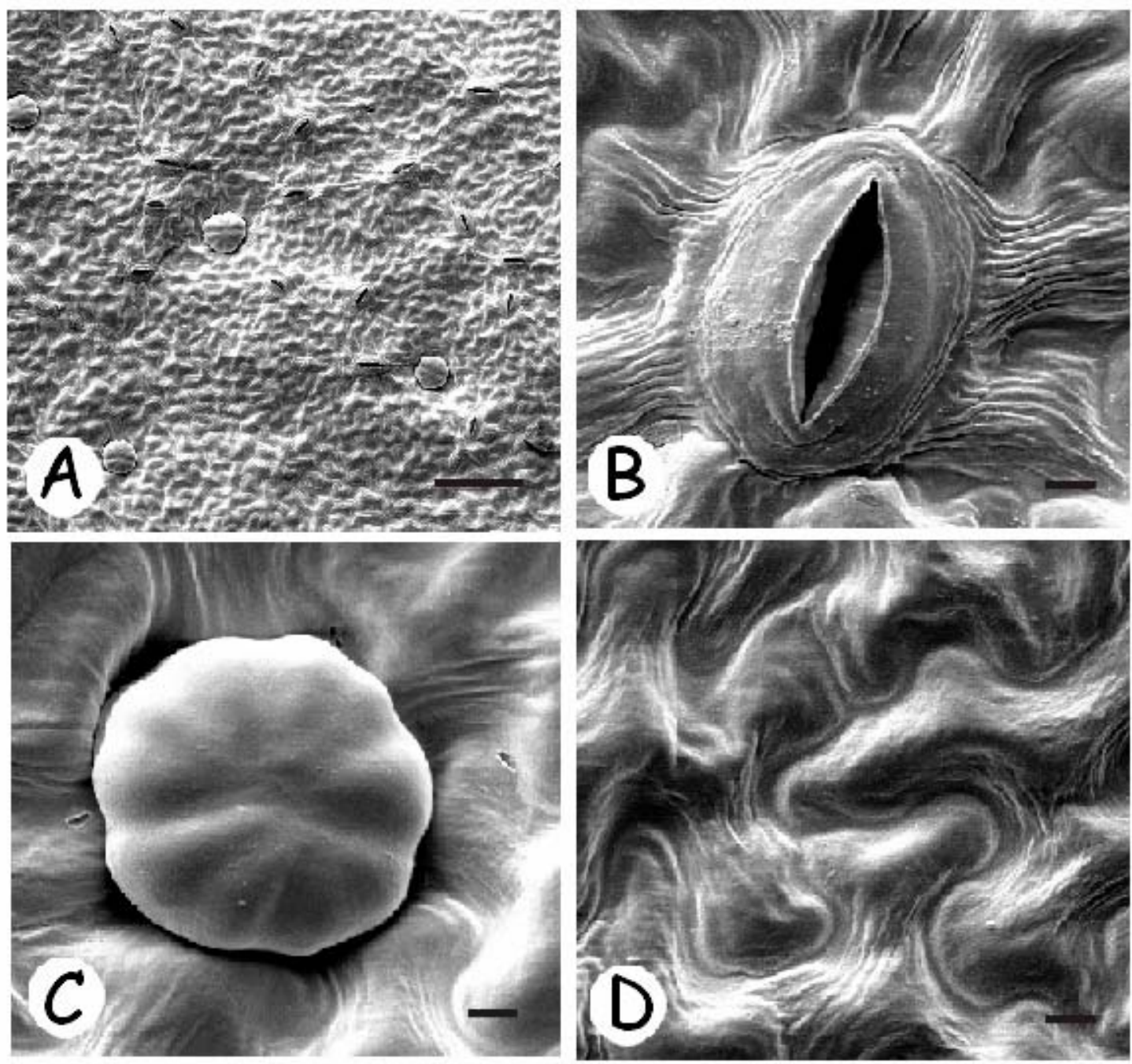

Figura 12 - Superfície foliar abaxial de Tecoma stans (amarelinho). A: Visão geral da superfície foliar (200x); B: Detalhe do estômato (2000x); C: Detalhe do tricoma glandular (2000x); D: Células epidérmicas (2000x). Barras: 100 $\mu \mathrm{m}, 5 \mu \mathrm{m}, 5 \mu \mathrm{m}$ e $5 \mu \mathrm{m}$, respectivamente 


\subsubsection{Convolvulaceae: Ipomoea grandifolia e Ipomoea purpurea}

Na Tabela 11 estão apresentadas as densidades estomáticas das espécies do gênero Ipomoea. As densidades estomáticas da superfície adaxial e abaxial das duas espécies não diferiram estatisticamente. Dentro de cada espécie as probabilidades das superfícies foliares não diferiram foram 3,61E-16 em I. grandifolia e 5,12E-14 em I. purpurea. Os estômatos dessas espécies foram classificados quanto à forma como paracíticos (Mauseth, 1988). Procópio et al. (2003) estudando a espécie I. cairica encontrou densidade estomática de 47 estômatos $/ \mathrm{mm}^{2}$ na superfície adaxial e 143 na superfície abaxial, valores estes bem próximos aos valores encontrados nas espécies $I$. grandifolia e I. purpurea.

Tabela 11. Densidade estomática de Ipomoea grandifolia (corda-de-viola) e Ipomoea purpurea (corda-de-viola). Piracicaba, SP, 2004

\begin{tabular}{|c|c|c|c|c|}
\hline & \multicolumn{4}{|c|}{$\begin{array}{l}\text { Densidade estomática } \\
\text { (estômatos } / \mathrm{mm}^{2} \text { ) }\end{array}$} \\
\hline & \multicolumn{2}{|c|}{ I. grandifolia } & \multicolumn{2}{|c|}{ I. purpurea } \\
\hline & adaxial & abaxial & adaxial & abaxial \\
\hline Média & 44,0 & 156,0 & 62,8 & 131,2 \\
\hline IC mínimo $^{1}$ & 32,2 & 137,4 & 54,2 & 118,7 \\
\hline IC máximo $^{1}$ & 55,8 & 174,6 & 74,4 & 143,7 \\
\hline $\mathrm{P}(\mathrm{T}<=\mathrm{t})^{2}$ & \multicolumn{2}{|c|}{$3,61 \mathrm{E}-16$} & \multicolumn{2}{|c|}{$5,12 \mathrm{E}-14$} \\
\hline Correlação & $-0,32$ & $-0,10$ & $-0,32$ & $-0,10$ \\
\hline
\end{tabular}

${ }^{1}$ IC: intervalo de confiança (t à 5\% de probabilidade).

${ }^{2}$ Teste t: duas amostras presumindo variâncias diferentes.

Pela Tabela 12 observou-se que a espécie I. purpurea apresentou maior quantidade de cera epicuticular que I. grandifolia, expressos em $\mu$ g de cera $/ \mathrm{cm}^{2}$. As ceras epicuticulares de I. grandifolia apresentaram 22,9 \% de compostos apolares e 77,1 \% de compostos polares. Quando se analisou a separação das ceras em compostos polares e apolares na espécie I. purpurea observou 36,3\% de compostos apolares e 63,7 
$\%$ de compostos polares, dados estes concordantes com os obtidos por Harr et al. (1991), que foram $31 \%$ de apolares e 68 \% de polares para a mesma espécie.

Tabela 12. Quantidades de ceras epicuticulares de presentes nas espécies Ipomoea grandifolia (corda-de-viola) e Ipomoea purpurea (corda-de-viola). Piracicaba, SP, 2004

\begin{tabular}{ccc}
\hline Parâmetro & I. grandifolia & I. purpurea \\
\hline Cera epicuticular $\left(\mu \mathrm{g} / \mathrm{cm}^{2}\right)$ & 22,1 & 53,2 \\
Fração apolar (\%) & 22,9 & 36,3 \\
Fração polar (\%) & 77,1 & 63,7 \\
\hline
\end{tabular}

No entanto, quando as características ultra-estruturais foram avaliadas observou-se pouca diferença nas ornamentações das superfícies foliares das duas espécies estudadas. As superfícies adaxiais de ambas possuíam tricomas unicelulares, estômatos e ceras dispostas na forma de estrias (Figuras 13 e 15). Nas superfícies abaxiais observou-se apenas presença de estômatos e com superfície sem depósitos de ceras epicuticulares (Figuras 14 e 16). Através das fotografias de microscopia eletrônica de varredura da I. purpurea obtidas por Harr et al. (1991), observou-se a presença de tricomas glandulares em ambas superfícies, no entanto nas observações obtidas nesta pesquisa foram encontrados apenas tricomas unicelulares na superfície adaxial. Estas fotografias obtidas por Harr et al. (1991), ainda mostraram ceras epicuticulares dispostas na forma de estrias na superfície adaxial e na superfície abaxial depósitos de ceras ausentes, corroborando com a presente pesquisa. Na Família Convolvulaceae foi observada presença de tricomas unicelulares e cutícula com cera epicuticular estriada na superfície adaxial.

Mendonça (2000a) estudando a superfície foliar de algumas plantas daninhas monocotiledôneas também encontrou diferenças nos depósitos de ceras epicuticulares entre as superfícies adaxial e abaxial. Nas espécies Brachiaria decumbens, Brachiaria plantaginea, Cenchrus echinatus e Panicum maximum foi observado maior 
epicuticulares na superfície adaxial e menor na abaxial. E observou proporções semelhantes de depósito de ceras epicuticulares em ambas superfícies foliares de Cynodon dactylon, Digitaria horizontalis, D. insularis e Eleusine indica. Estas características favoreceram uma maior área de molhamento de soluções com diferentes tensões superficiais nas superfícies foliares com menor depósito de ceras epicuticulares. 

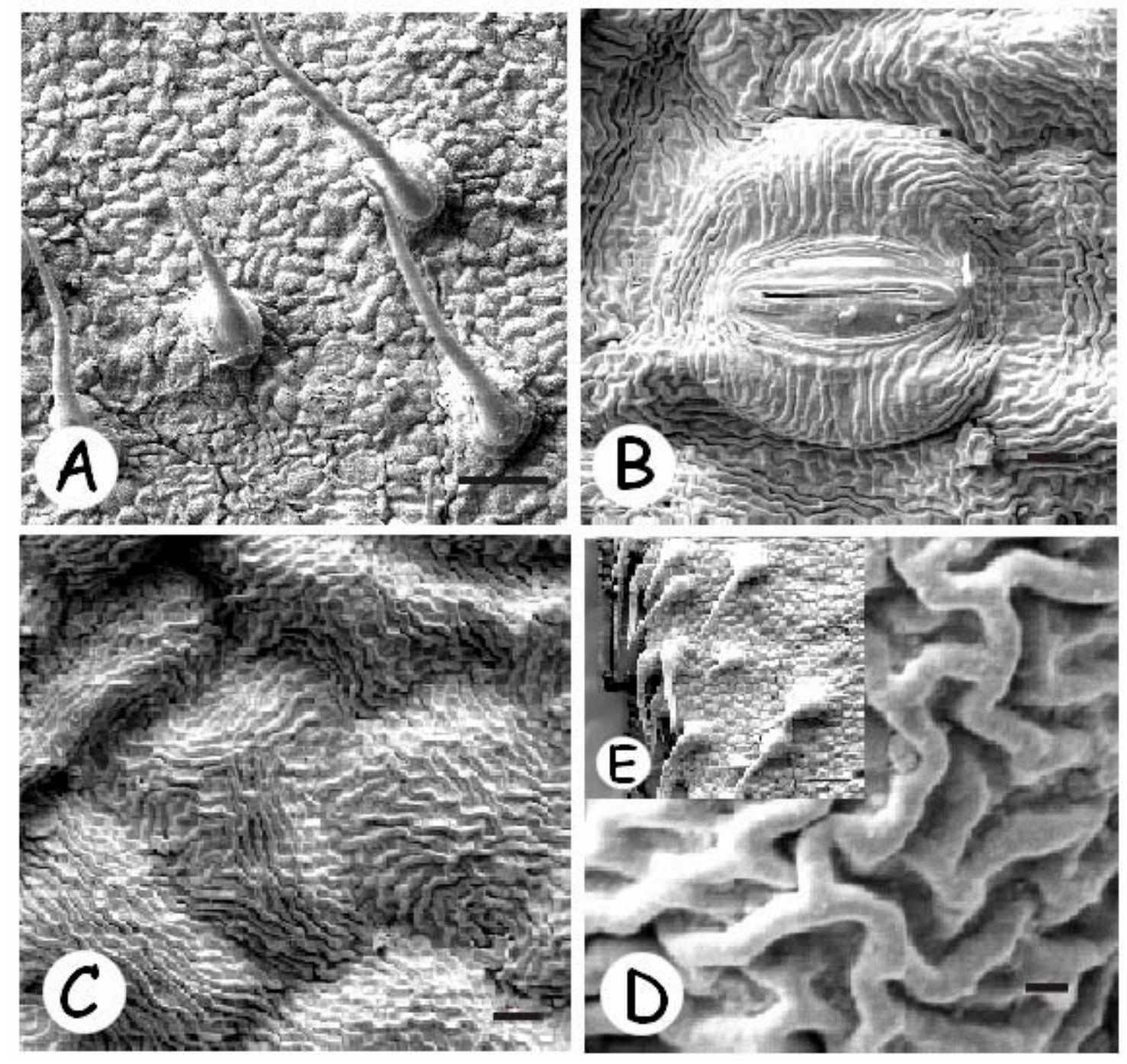

Figura 13 - Superfície foliar adaxial de Ipomoea grandifolia (corda-de-viola). A: Visão geral da superfície foliar (200x); B: Detalhe do estômato (2000x); C: Detalhe da superfície das células epidérmicas (2000x); D: Detalhe da superfície foliar (10000x); E: Detalhe do bordo foliar (200x). Barras: 100 $\mu \mathrm{m}, 5 \mu \mathrm{m}, 5 \mu \mathrm{m}, 2 \mu \mathrm{m}$ e $100 \mu \mathrm{m}$, respectivamente 

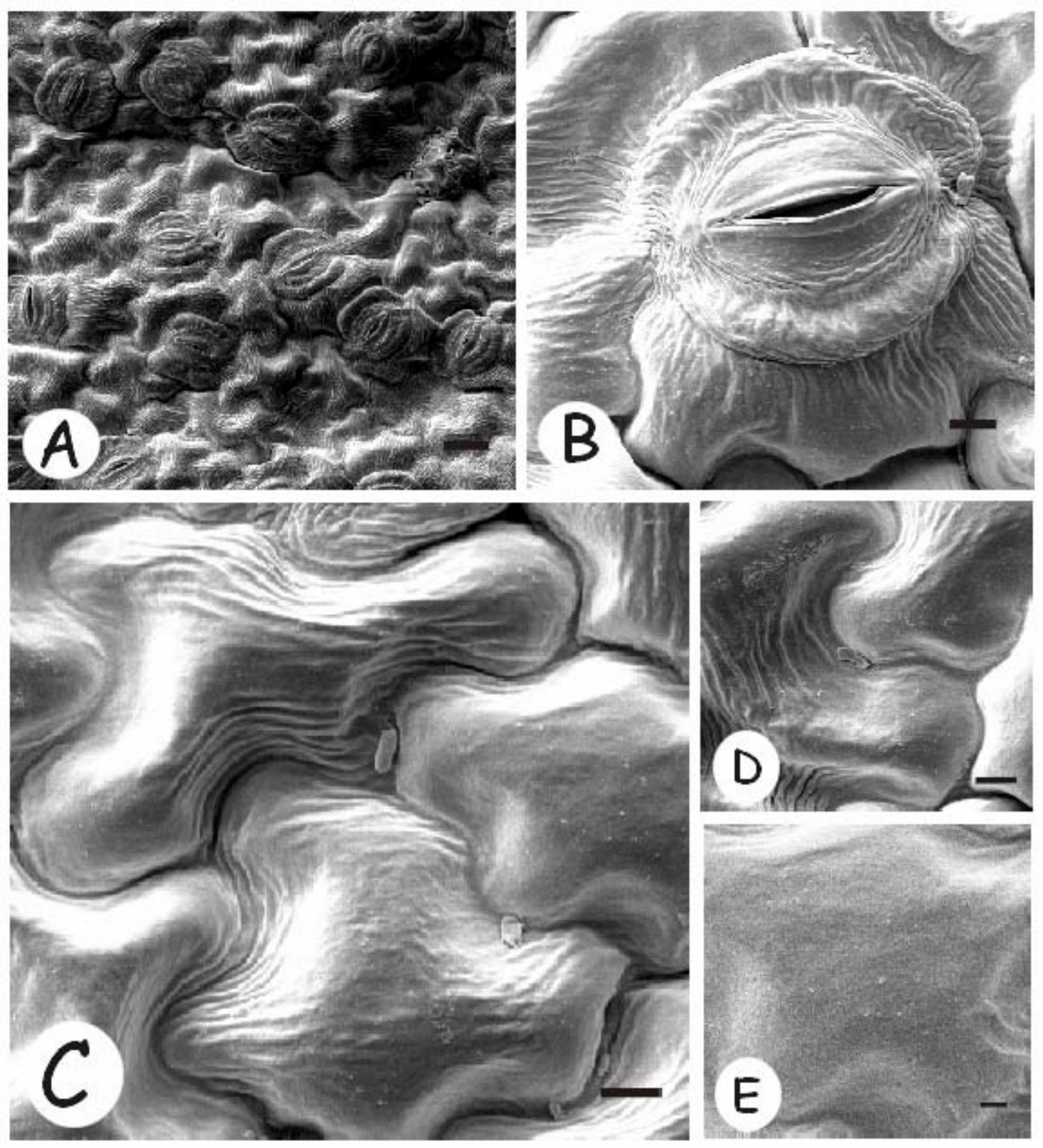

Figura 14 - Superfície foliar abaxial de Ipomoea grandifolia (corda-de-viola). A: Visão geral da superfície foliar (500x); B: Detalhe do estômato (2000x); C: Detalhe da superfície das células epidérmicas (2000x); D: Detalhe da superfície foliar (3000x); E: Detalhe da superfície foliar (5000x). Barras: 20 $\mu \mathrm{m}, 5 \mu \mathrm{m}, 5 \mu \mathrm{m}, 5 \mu \mathrm{m}$ e $2 \mu \mathrm{m}$, respectivamente 

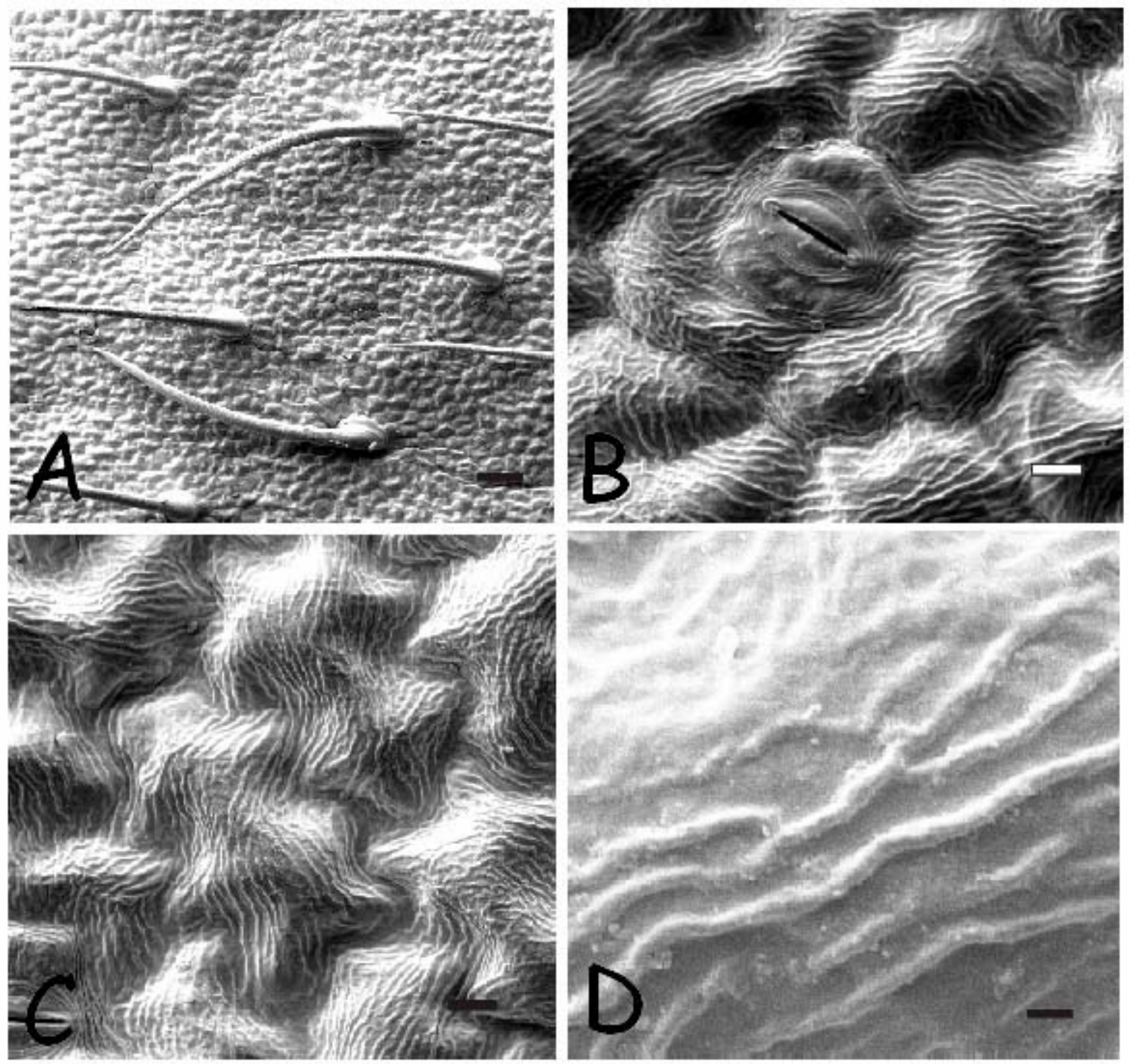

Figura 15 - Superfície foliar adaxial de Ipomoea purpurea (corda-de-viola). A: Visão geral da superfície foliar (100x); B: Detalhe do estômato (1000x); C: Detalhe da superfície das células epidérmicas (1000x); D: Detalhe da superfície foliar (5000x). Barras: $100 \mu \mathrm{m}, 10 \mu \mathrm{m}, 10 \mu \mathrm{m}$ e $2 \mu \mathrm{m}$, respectivamente 

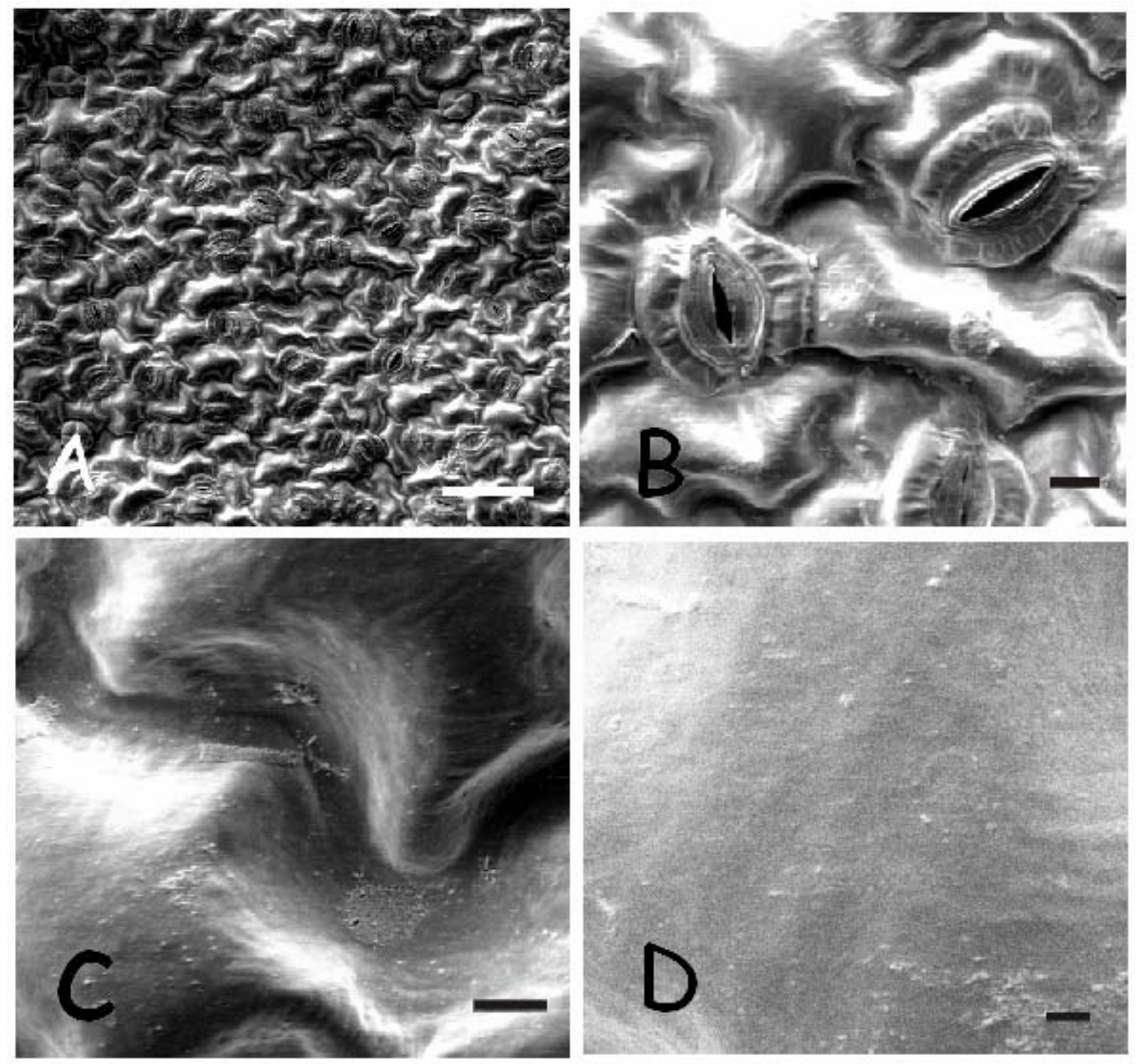

Figura 16 - Superfície foliar abaxial de Ipomoea purpurea (corda-de-viola). A: Visão geral da superfície foliar (200x); B: Detalhe dos estômatos (1000x); C: Detalhe da superfície das células epidérmicas (3000x); D: Detalhe da superfície foliar (5000x). Barras: $100 \mu \mathrm{m}, 10 \mu \mathrm{m}, 10 \mu \mathrm{m}$ e $2 \mu \mathrm{m}$, respectivamente 


\subsection{Conclusões}

Para as condições em que esta pesquisa foi realizada, pôde-se concluir:

a) A espécie Memora peregrina apresentou grande quantidade de estômatos na superfície abaxial e ausência na superfície adaxial.

b) As espécies da Família Bignoniaceae estudadas apresentaram semelhantes porcentagens de compostos apolares e polares das ceras epicuticulares.

c) As superfícies foliares de folhas velhas de $M$. peregrina apresentaram grande quantidade de depósito de ceras epicuticulares.

d) As densidades estomáticas das superfícies adaxiais das espécies $I$ grandifolia e I. purpurea não diferiram estatisticamente, o mesmo comportamento foi observado nas superfícies abaxiais.

e) As espécies I. grandifolia e I. purpurea apresentaram tricomas unicelulares e cera epicuticular estriada na superfície adaxial. 


\section{CARACTERÍSTICAS DAS SUPERFÍCIES FOLIARES DE PLANTAS DANINHAS. III - EUPHORBIACEAE: Euphorbia heterophylla e MALVACEAE:}

Sida rhombifolia e Sida glaziovii

\section{Resumo}

As superfícies foliares de plantas daninhas são os alvos que o herbicida veiculado na calda de pulverização deve atingir. O conhecimento das características das superfícies foliares determina a utilização mais adequada do herbicida e conseqüentemente sua eficácia no controle. O objetivo deste trabalho foi avaliar a densidade estomática, a porcentagem de compostos polares e apolares das ceras epicuticulares e observar as características ultra-estruturais da cutícula foliar de Euphorbia heterophylla, Sida glaziovii e Sida rhombifolia. A densidade estomática foi determinada em ambas superfícies foliares das espécies vegetais, imprimindo a epiderme foliar em lâmina de vidro usando cola adesiva. Na determinação dos compostos polares e apolares das ceras epicuticulares, as folhas foram imersas em clorofórmio e as amostras foram fracionadas em coluna de sílica gel, onde com o solvente hexano obtevese os compostos apolares e com o clorofórmio, os polares. Para avaliação da quantidade de cera por unidade de área foliar foi determinada a área foliar destas folhas após a imersão em clorofórmio. A análise ultra-estrutural de superfícies foliares foi realizada observando imagens obtidas com a Microscopia Eletrônica de Varredura. As densidades estomáticas de E. heterophylla foram 140,5 estômatos $/ \mathrm{mm}^{2}$ na superfície adaxial e 215,2 na abaxial. O depósito de cera epicuticular foi na forma de cristais nas duas superfícies avaliadas. As espécies S. rhombifolia e $S$. glaziovii não apresentaram diferenças 
estatísticas nas densidades estomáticas das superfícies foliares. As espécies do gênero Sida avaliadas apresentaram maiores porcentagens de compostos polares.

\section{FOLIAR SURFACES CHARACTERISTICS OF WEEDS. III - EUPHORBIACEAE: Euphorbia heterophylla and MALVACEAE: Sida rhombifolia and Sida glaziovii}

\section{Summary}

The foliar surfaces of weeds are the target that the herbicide should reach. The knowledge of the characteristic of the foliar surfaces determines the use more adequate of the herbicide. The objective of this research was to evaluate the stomatal density, the polar and apolar compounds percentage of the epicuticular waxes and to analyze the ultra-structural of the cuticle of Euphorbia heterophylla, Sida glaziovii and Sida rhombifolia. The number stomata for unit of foliar area (stomatal density) was determined in both foliar surfaces of the plants, with the impression of the foliar epidermis in sheet of glass using glue. In the determination of the polar and apolar compounds of the epicuticular waxes, the leaves were dipped in chloroform and the samples were divided using a column of silica gel, where the solvent hexane extracted the apolar compounds and the chloroform extracted the polar compounds from this column. The leaves were dipped in chloroform to extract the epicuticular wax and after were determined foliar area. The ultra-structural analyses of the foliar surfaces were determined observing images obtained with Scanning Electronic Microscopy. The stomatal density of E. heterophylla was 140.5 stomatas $/ \mathrm{mm}^{2}$ in adaxial surface and 215.2 in abaxial surface. The deposit of epicuticular waxes was in form of crystals in both foliar surfaces of E. heterophylla. The stomatal densities of the foliar surfaces of $S$. rhombifolia and S. glaziovii had not statistical differences. The species of the Sida genus had great percentage of polar compounds. 


\subsection{Introdução}

As plantas daninhas competem com as plantas cultivadas por água, luz e nutrientes, e em certas ocasiões são tóxicas aos animais, como no caso de algumas invasoras de pastagens.

O conhecimento das estruturas funcionais presentes nas folhas (ceras, estômatos, tricomas e apêndices) elucida as possíveis interações entre os herbicidas e as superfícies foliares das plantas daninhas, durante o processo de absorção. Após a absorção do herbicida pela planta, este poderá ser translocado ou não, fato este definido principalmente pelas características químicas da molécula, chegando ao seu sítio de ação e causando a morte da planta daninha.

As plantas daninhas estudadas são da Classe Dicotiledônea e são comumente chamadas de folhas largas. Na Tabela 13 estão apresentadas informações quanto à família, nome científico, nomes comuns e código internacional de cada espécie.

Tabela 13. Famílias, espécies, nomes comuns e códigos internacionais das espécies de plantas daninhas dicotiledôneas

\begin{tabular}{cllc}
\hline Família & \multicolumn{1}{c}{ Nome Científico } & \multicolumn{1}{c}{ Nome Comum } & Cód. Int. \\
\hline Euphobiaceae & Euphorbia heterophylla L. & Amendoim-bravo, leiteira (RS), parece- & EPHHL \\
& & mas-não-é (PE), flor-de-poeta, adeus-brasil & \\
& & $(\mathrm{RS})$, café-do-bispo (RS), leiteiro, café-do- & \\
Malvaceae & Sida rhombifolia L. & diabo, mata-brasil & SIDRH \\
& & Guanxuma, mata-pasto (SC), vassourinha, & \\
& & relógio, vassoura-relógio (BA), guaxima, & malva, vassourinha-do-campo, malva-preta \\
& Sida glaziovii K. Schum. & Guanxuma-branca, malva-guaxuma & SIDGZ
\end{tabular}

Fonte: Lorenzi (2000). 
Lorenzi (2000) e Kissmann \& Groth (2000) descrevem a espécie Euphorbia heterophylla L. como uma planta anual, ereta, herbácea, leitosa, de folhas muito variáveis, com caule glabro ou variavelmente pubescente, de $30-80 \mathrm{~cm}$ de altura, nativa do Continente Americano e propaga-se por sementes.

Dentre as espécies estudadas da Família Malvaceae, Lorenzi (2000) e Kissmann \& Groth (2000) descrevem a espécie Sida rhombifolia L. como uma planta anual ou perene, subarbustiva, ereta, de 30-80 cm de altura e nativa do Continente Americano. Infestam principalmente lavouras anuais e perenes, pomares, jardins, pastagens e terrenos baldios. A espécie Sida glaziovii K. Schum. é uma planta perene, herbácea ou subarbustiva, ereta ou subprostrada, ramificada, de caule revestido de pubescência esbranquiçada, de 30-90 cm de altura e nativa do Brasil. Propaga-se por sementes, infestando principalmente áreas destinadas a pastagens, beira de estradas, carreadores, pomares e culturas perenes em geral.

Para o sucesso de pulverizações de agroquímicos, é fundamental o conhecimento das influências intrínsecas às plantas (disposição das folhas, $\mathrm{pH}$ foliar, ceras epicuticulares, estômatos, tricomas, etc) e das influências extrínsecas, como características físico-químicas da solução de pulverização (tensão superficial, área de molhamento, pH da solução, tipo de formulação, etc) (Mendonça, 2000a).

A cutícula consiste de cutina, ceras epicuticulares, ceras cuticulares e pectina, sendo que a sua ordem crescente de lipofilicidade da cutícula é pectina $<$ cutina $<$ cera (Hess, 1997). As ceras epicuticulares podem ser encontradas na forma de placas, tubos, fitas, vara, filamentos e dentritos (Baker, 1991). O tipo de estrutura de cera influencia a capacidade de molhamento da solução de pulverização. Geralmente superfícies foliares lisas e isentas de cristais de ceras epicuticulares são relativamente fáceis de molhar (como em muitas espécies de dicotiledôneas). Superfícies foliares cobertas com cristais de ceras epicuticulares são muito mais difíceis para molhar, como em muitas espécies de monocotiledôneas (Hess, 1997).

As propriedades físico-químicas da cutícula influenciam o comportamento da gota de pulverização, podendo afetar a taxa e eficiência da 
penetração cuticular (Kirkwood, 1999). Segundo Wirth et al.(1991), a aplicação do ingrediente ativo começa com a preparação da solução de pulverização e é seguida pela pulverização, trajetória e impacto na superfície da folha, salienta ainda que para obter a máxima eficácia na aplicação cada passo deve ser otimizado. Na aplicação de agroquímicos, Bukovac \& Petracek (1993) acreditam que a penetração foliar começa quando a solução é retida pela superfície da planta. Esse é um processo contínuo, consistindo de três etapas: sorção, difusão e desorção.

O objetivo desta pesquisa foi estudar as características ultra-estruturais de superfícies foliares das seguintes plantas daninhas: Euphorbia heterophylla L., Sida rhombifolia L. e Sida glaziovii K. Schum., pela determinação da densidade estomática, pela caracterização das ceras epicuticulares determinando sua massa e a porcentagem de compostos polares e apolares e por observações em microscopia eletrônica de varredura.

\subsection{Material e Métodos}

As plantas foram cultivadas em condições de casa-de-vegetação do Departamento de Produção Vegetal da ESALQ/USP, com temperatura variando de 15 a 35 ${ }^{\circ} \mathrm{C}$, com turno de irrigação diário. O solo utilizado para o cultivo das plantas daninhas apresentava as seguintes características físicas: 64\% de areia total, 26 \% de argila e $10 \%$ de silte, classificado como textura média argilosa. As características químicas do solo utilizado estão apresentadas na Tabela 14. As plantas daninhas avaliadas encontravamse com aproximadamente $30 \mathrm{~cm}$ de altura.

Tabela 14. Características químicas do solo (macronutrientes e micronutrientes). Piracicaba, SP, 2004

\begin{tabular}{lllllllllllllll}
\hline $\mathrm{PH}$ & $\mathrm{M} . \mathrm{O}$. & $\mathrm{B}$ & $\mathrm{Cu}$ & $\mathrm{Fe}$ & $\mathrm{Mn}$ & $\mathrm{Zn}$ & $\mathrm{P}_{\text {resina }}$ & $\mathrm{H}+\mathrm{Al}$ & $\mathrm{K}$ & $\mathrm{Ca}$ & $\mathrm{Mg}$ & $\mathrm{SB}$ & $\mathrm{CTC}$ & $\mathrm{V} \%$
\end{tabular}




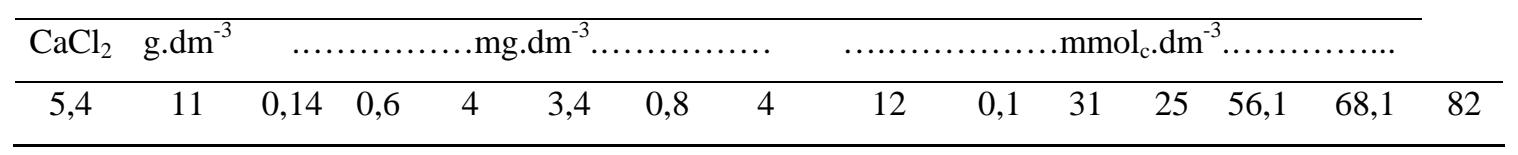

\subsubsection{Densidade estomática}

O número de estômatos por unidade de área de epiderme foliar (densidade estomática) foi determinado nas superfícies adaxial e abaxial das folhas das plantas daninhas. Utilizou-se a técnica de impressão de epiderme em adesivo a base de éster de cianoacrilato (Mendonça, 2000a). Para tanto, uma gota do adesivo foi depositada em lâmina de vidro para microscopia, colocando a folha com a superfície desejada voltada para a cola pressionando-a na lâmina. Após secagem do adesivo, o material vegetal foi retirado, permanecendo a impressão da epiderme na lâmina. A densidade estomática foi determinada em microscópio ótico de luz (Marca Carl Zeiss, Modelo Axio Skop 2), acoplado ao computador com o software Axiovision. Nas avaliações da densidade estomática das superfícies foliares foram utilizadas 50 repetições. Os dados foram analisados estatisticamente pelo valor de t $(\mathrm{P}>0,05)$, determinando os intervalos de confiança mínimo e máximo, também foi analisado o nível de significância em que as médias das superfícies foliares (adaxial e abaxial) foram diferentes, pelo Teste t entre as duas superfícies, utilizando o software Excel.

\subsubsection{Separação dos compostos polares e apolares}

Os compostos polares e apolares das ceras epicuticulares foram separados segundo metodologia utilizada por Mendonça (2000a). As ceras foram extraídas mergulhando as folhas em clorofórmio por 30 segundos, tomando-se o cuidado para não expor o corte ao solvente. Determinou-se a área foliar das folhas para calcular a quantidade de $\mu$ g de cera/ $\mathrm{cm}^{2}$. A amostra foi filtrada em papel de filtro e o solvente foi evaporado. Para as determinações de ceras totais as alíquotas foram transferidas para vials de $4 \mathrm{~mL}$, secas totalmente e pesadas em balança com precisão de 0,0001 g. Para o fracionamento de 
compostos polares e apolares a cera foi redissolvida em 0,5 mL de clorofórmio, colocada em coluna empacotada de sílica gel $(\mathrm{SiOH})$. Esta coluna foi mantida a vácuo para total secagem do solvente, em seguida foi realizada a seguinte sequência de solventes: $20 \mathrm{~mL}$ de hexano e $20 \mathrm{~mL}$ de clorofórmio, sendo estes solventes coletados separadamente. Foram obtidas duas frações da amostra, onde a fração extraída pelo hexano correspondeu a apolar e a extraída pelo clorofórmio a menos apolar, chamada de "polar”. Os solventes foram evaporados e pesados em balança de precisão de 0,0001g.

\subsubsection{Análise ultra-estrutural da epiderme foliar}

Os estudos ultra-estruturais da epiderme foliar foram realizados através de Microscopia Eletrônica de Varredura (MEV), caracterizando as faces adaxial e abaxial da região mediana da lâmina foliar das espécies de plantas daninhas e foram conduzidos no Núcleo de Apoio à Pesquisa/ Microscopia Eletrônica Aplicada à Pesquisa Agropecuária (NAP/MEPA), da ESALQ/USP.

Protocolo de preparo de amostra para observação em microscópio eletrônico de varredura (Kitajima \& Leite, 1999): amostras foliares com dimensões aproximadas de 2x2 mm, foram fixadas em solução de fixador "Karnovsky" (glutaraldeído 2,5 \%, formaldeído 2,5 \% em tampão cacodilato de sódio 0,05 M, pH 7,2, $\mathrm{CaCl}_{2}$ 0,001 M), por uma hora. Em seguida, as amostras foram lavadas em tampão cacodilato 0,05 M por três vezes e pós-fixadas em tetraóxido de ósmio $1 \%$ em tampão cacodilato 0,05 M, pH 7,2 por uma hora em temperatura ambiente. As amostras fixadas no tetraóxido de ósmio foram lavadas com água destilada e desidratadas por uma série de concentração crescente de acetona (30, 50, 70 e 90 \%) uma vez cada por 10 minutos e em 100 \% de acetona por três vezes de 10 minutos. Nas amostras realizou-se a secagem ao ponto crítico com a finalidade de retirar a acetona das amostras foliares, substituindo-a por $\mathrm{CO}_{2}$ líquido, em seguida mudando seu estado físico para gasoso (Marca Balzers e Modelo CPD 050). Em seguida as amostras foram metalizadas com ouro (Marca Balzers e Modelo MED 010). 
Os materiais foram observados ao Microscópio Eletrônico de Varredura da Marca Zeiss e do Modelo DSM900. As imagens selecionadas nas observações ao microscópio eletrônico de varredura foram trabalhadas no software Corel Photo-Paint 9.0 para montagem das figuras.

\subsection{Resultados e Discussão}

\subsubsection{Euphorbiaceae: Euphorbia heterophylla}

Na Tabela 15 estão apresentados os dados da densidade estomática de $E$. heterophylla, onde observa-se a densidade foi 140,5 estômatos/ $\mathrm{mm}^{2}$ de área foliar na superfície adaxial e 215,2 na abaxial, com probabilidade de 1,7E-11 de não serem diferentes. Quanto à forma os estômatos foram classificados como anomocíticos (Mauseth, 1988). Ferreira et al. (2003), estudando as características anatômicas desta espécie também observou densidade estomática de 138 e 188 estômatos $/ \mathrm{mm}^{2}$ na superfície adaxial e abaxial.

Tabela 15. Densidade estomática de Euphorbia heterophylla (amendoim-bravo). Piracicaba, SP, 2004

\begin{tabular}{ccc}
\hline & \multicolumn{2}{c}{$\begin{array}{c}\text { Densidade estomática (estômatos } / \mathrm{mm}^{2} \text { ) } \\
\text { adaxial }\end{array}$} \\
\hline Média & 140,5 & 215,2 \\
IC mínimo $^{1}$ & 128,8 & 199,8 \\
IC máximo $^{1}$ & 152,3 & 230,6 \\
$\mathrm{P}(\mathrm{T}<=\mathrm{t})^{2}$ & & $1,7 \mathrm{E}-11$ \\
\hline
\end{tabular}

\footnotetext{
${ }^{1}$ IC: intervalo de confiança (t à 5\% de probabilidade).

${ }^{2}$ Teste t: duas amostras presumindo variâncias diferentes.
}

Na Tabela 16 estão apresentados os estudos das ceras epicuticulares de $E$. heterophylla, apresentando 46,0 $\mathrm{gg}$ de cera/ $\mathrm{cm}^{2}$, sendo estes 48,9\% de compostos 
apolares e 51,1 \% de polares, mostrando assim um equilíbrio na porcentagem desses compostos.

Tabela 16. Quantidades de ceras epicuticulares de presentes na espécie Euphorbia heterophylla (amendoim-bravo). Piracicaba, SP, 2004

\begin{tabular}{cc}
\hline Parâmetro & Média \\
\hline Cera epicuticular $\left(\mu \mathrm{g} / \mathrm{cm}^{2}\right)$ & 46,0 \\
Fração apolar $(\%)$ & 48,9 \\
Fração polar (\%) & 51,1 \\
\hline
\end{tabular}

Dentre as espécies analisadas esta espécie foi a que apresentou maior quantidade de depósitos de cristais de ceras epicuticulares nas duas superfícies foliares avaliadas (Figuras 17 e 18). Os estômatos estavam embebidos nas células epidérmicas (Figuras 17B e 18C). Na superfície abaxial foi observada presença de tricomas unicelulares longos (Figura 18AD). 

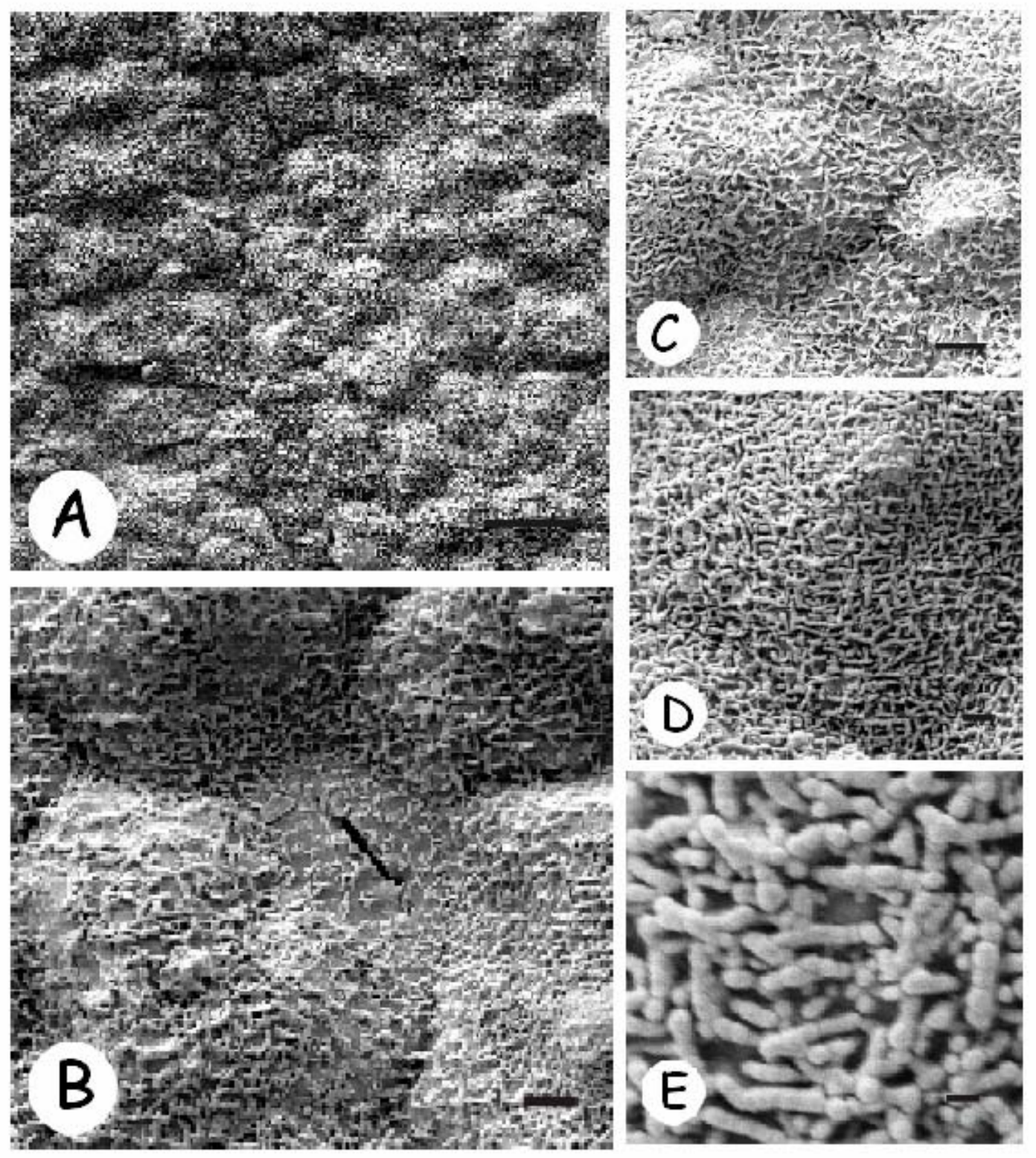

Figura 17 - Superfície foliar adaxial de Euphorbia heterophylla (amendoim-bravo). A: Visão geral da superfície foliar (200x); B: Detalhe do estômato (2000x); C: Detalhe da superfície das células epidérmicas (3000x); D: Cera epicuticular (5000x); E: Detalhe da cera epicuticular (20000x). Barras: $100 \mu \mathrm{m}, 5 \mu \mathrm{m}$, $5 \mu \mathrm{m}, 2 \mu \mathrm{m}$ e $0,5 \mu \mathrm{m}$, respectivamente 

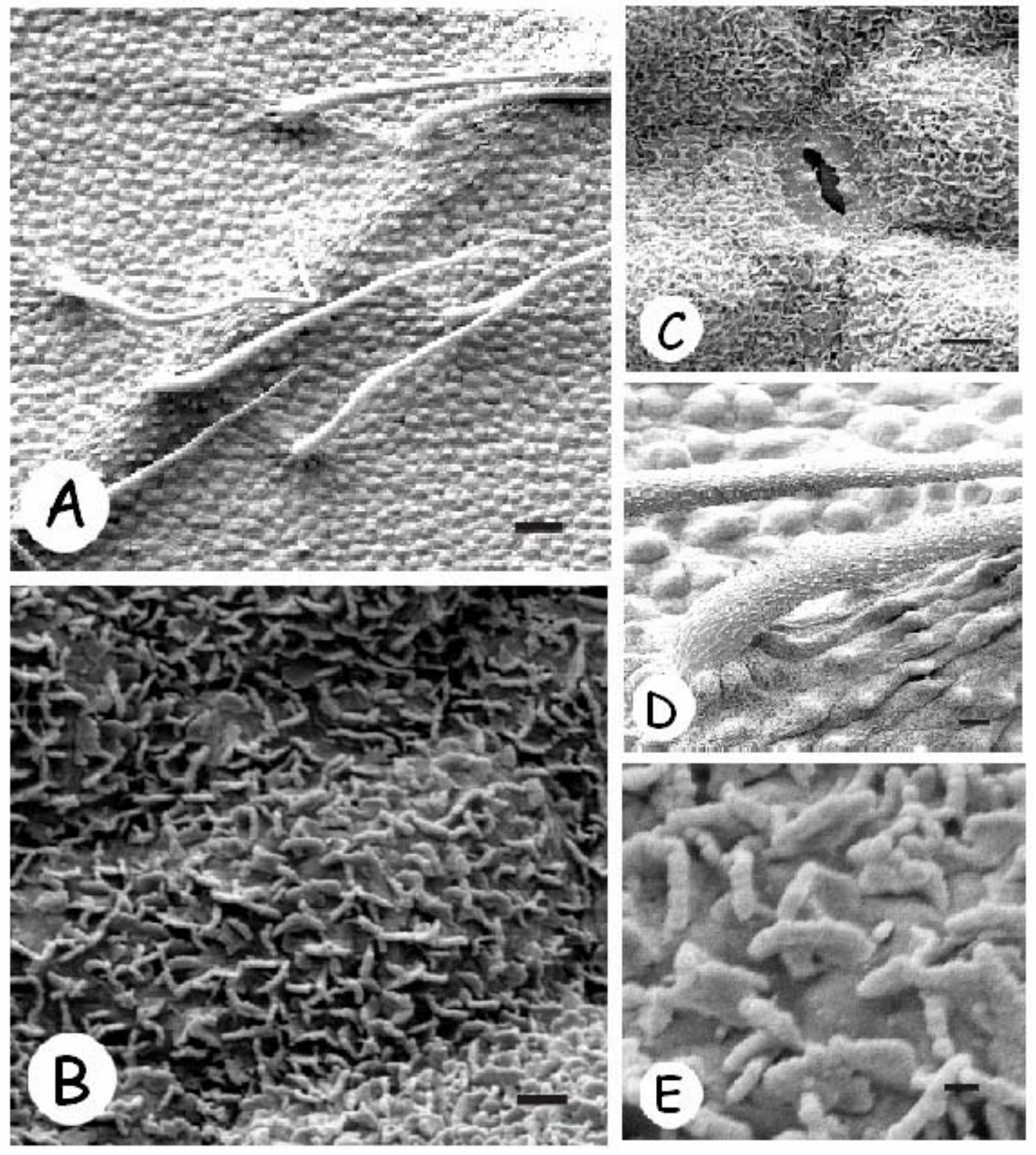

Figura 18 - Superfície foliar abaxial de Euphorbia heterophylla (amendoim-bravo). A: Visão geral da superfície foliar (100x); B: Detalhe da superfície das células epidérmicas (5000x); C: Detalhe do estômato (3000x); D: Detalhe dos tricomas (500x); E: Detalhe da cera epicuticular (20000x). Barras: $100 \mu \mathrm{m}$, $2 \mu \mathrm{m}, 5 \mu \mathrm{m}, 20 \mu \mathrm{m}$ e $0,5 \mu \mathrm{m}$, respectivamente 


\subsubsection{Malvaceae: $\underline{\text { Sida rhombifolia e Sida glaziovii }}$}

Na Tabela 17 estão apresentadas as análises dos dados de densidade estomática das espécies da família Malvaceae estudadas. Não foi verificada diferença estatística na densidade estomática entre as superfícies adaxiais das espécies avaliadas e entre as superfícies abaxiais destas espécies. Os estômatos foram classificados quanto à forma como anomocíticos (Mauseth, 1988). Na espécie S. glaziovii Procópio et al. (2003) encontrou densidade estomática de 86 estômatos $/ \mathrm{mm}^{2}$ na superfície adaxial e 390 na superfície abaxial. Estes resultados foram discordantes, todavia na pesquisa citada, a idade exata da espécie avaliada não está explícita, podendo ser esta uma das possíveis explicações para estes dados discordantes.

Tabela 17. Densidade estomática de Sida rhombifolia (guanxuma) e Sida glaziovii (guanxuma-branca). Piracicaba, SP, 2004

\begin{tabular}{ccccc}
\hline & \multicolumn{3}{c}{ Densidade estomática (estômatos $/ \mathrm{mm}^{2}$ ) } \\
& adaxial & abaxial & adaxial & Abaxial \\
\hline Média & 101,1 & 212,6 & 118,6 & 187,3 \\
IC mínimo $^{1}$ & 94,5 & 195,2 & 113,3 & 175,6 \\
IC máximo $^{1}$ & 107,7 & 230,1 & 123,8 & 199 \\
P $(\mathrm{T}<=\mathrm{t})^{2}$ & \multicolumn{2}{c}{$9,16 \mathrm{E}-18$} & \multicolumn{2}{c}{$3,48 \mathrm{E}-16$} \\
Correlação $^{2}$ & 0,13 & $-0,02$ & 0,13 & $-0,02$ \\
\hline
\end{tabular}

\footnotetext{
${ }^{1}$ IC: intervalo de confiança (t à 5\% de probabilidade).

${ }^{2}$ Teste t: duas amostras presumindo variâncias diferentes.
}

A quantidade de cera epicuticular por área foliar das espécies avalidas foram semelhantes. Observou-se ainda, uma maior quantidade de compostos polares nas ceras epicuticulares nas espécies S. rhombifolia e S. glaziovii. (Tabela 18). 
Tabela 18. Quantidades de ceras epicuticulares presentes nas espécies de Sida rhombifolia (guanxuma) e Sida glaziovii (guanxuma-branca). Piracicaba, SP, 2004

\begin{tabular}{ccc}
\hline Parâmetro & S. rhombifolia & S. glaziovii \\
\hline Cera epicuticular $\left(\mu \mathrm{g} / \mathrm{cm}^{2}\right)$ & 14,6 & 15,4 \\
Fração apolar $(\%)$ & 24,1 & 37,9 \\
Fração polar $(\%)$ & 75,9 & 62,1 \\
\hline
\end{tabular}

Nas Figuras 19 e 20 estão apresentadas as superfícies foliares de $S$. rhombifolia, observou-se a presença de estômatos em ambas as superfícies e tricomas unicelulares na face adaxial. Ocorreu a presença de tricomas estelares na superfície abaxial, porém Albert (2000) observou tricomas estelares em ambas superfícies foliares. Também foram observados na superfície abaxial tricomas glandulares (Figura 20F) e depósito de cera na forma de estrias nas superfícies adaxial e abaxial (Figuras 19D e 20C).

Nas Figuras 21 e 22 estão caracterizadas as superfícies foliares de $S$. glaziovii, onde se observou a presença de tricomas estelares em ambas as superfícies, estando de acordo com as observações de Albert (2000). Em ambas superfícies observou-se a presença de estômatos e tricomas glandulares. A superfície adaxial de S. glaziovii apresentou maior depósito de ceras epicuticulares do na superfície abaxial, depósito este na forma de estrias (Figuras 21C e 22F). 

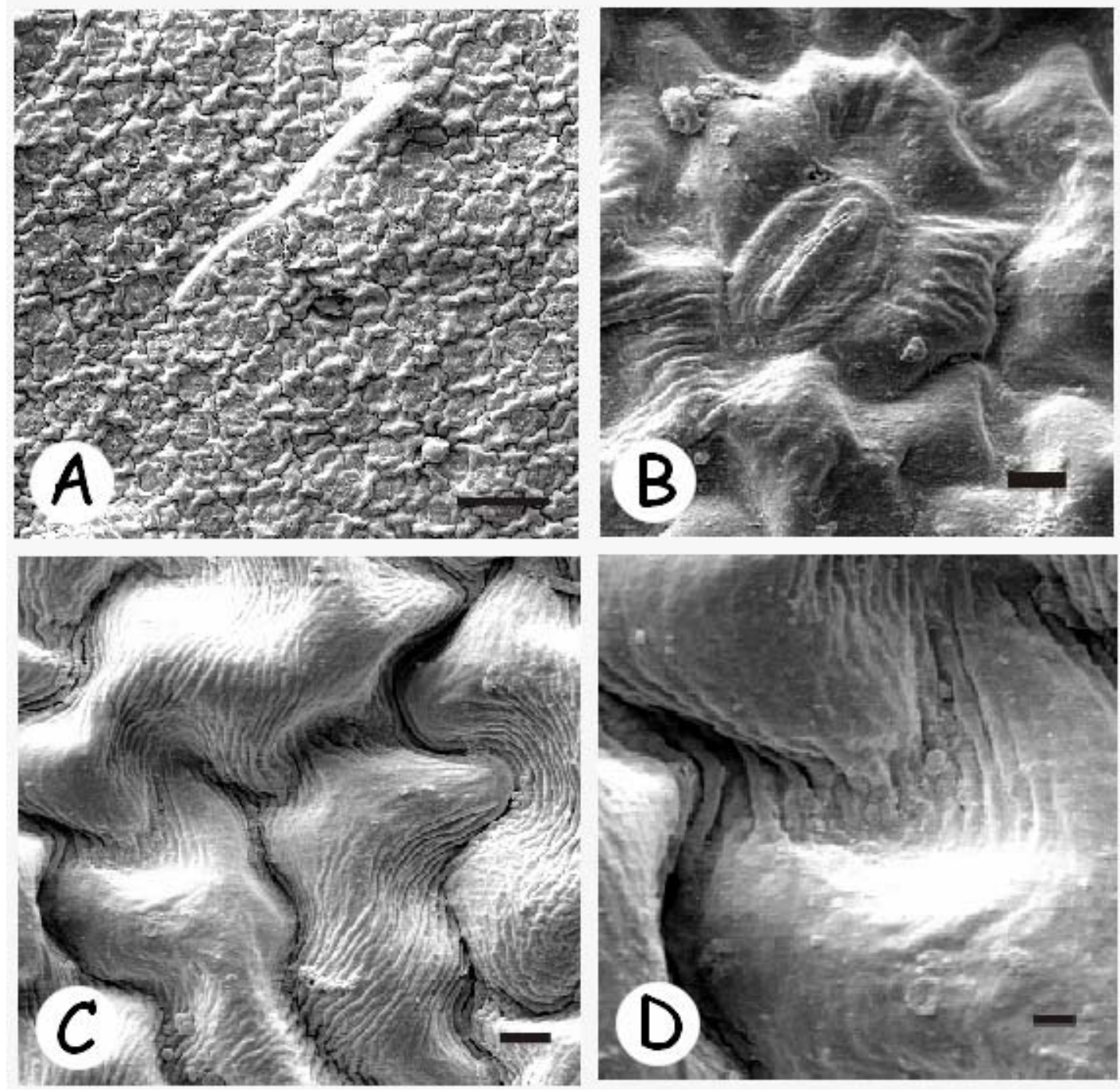

Figura 19 - Superfície foliar adaxial de Sida rhombifolia (guanxuma). A: Visão geral da superfície foliar (200x); B: Detalhe do estômato (2000x); C: Detalhe da superfície das células epidérmicas (2000x); D: Detalhe da superfície foliar (5000x). Barras: $100 \mu \mathrm{m}, 5 \mu \mathrm{m}, 5 \mu \mathrm{m}$ e $2 \mu \mathrm{m}$, respectivamente 

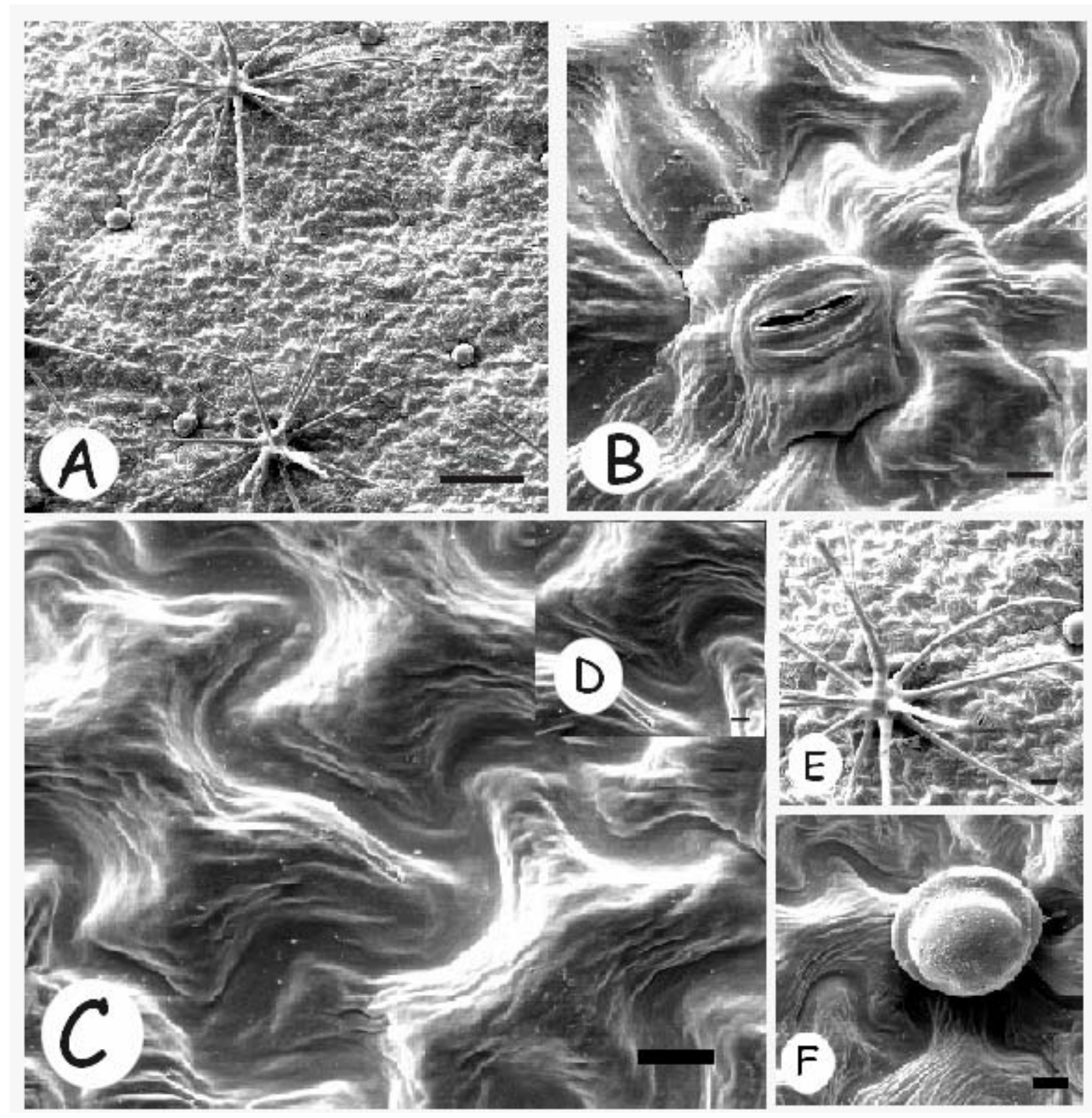

Figura 20 - Superfície foliar abaxial de Sida rhombifolia (guanxuma). A: Visão geral da superfície foliar (200x); B: Detalhe do estômato (2000x); C: Detalhe da superfície das células epidérmicas (2000x); D: Detalhe da superfície foliar (5000x); E: Detalhe do tricoma estelar (500x); F: Detalhe do tricoma glandular (2000x). Barras: $100 \mu \mathrm{m}, 5 \mu \mathrm{m}, 5 \mu \mathrm{m}, 20 \mu \mathrm{m}, 5 \mu \mathrm{m}$ e $2 \mu \mathrm{m}$, respectivamente 

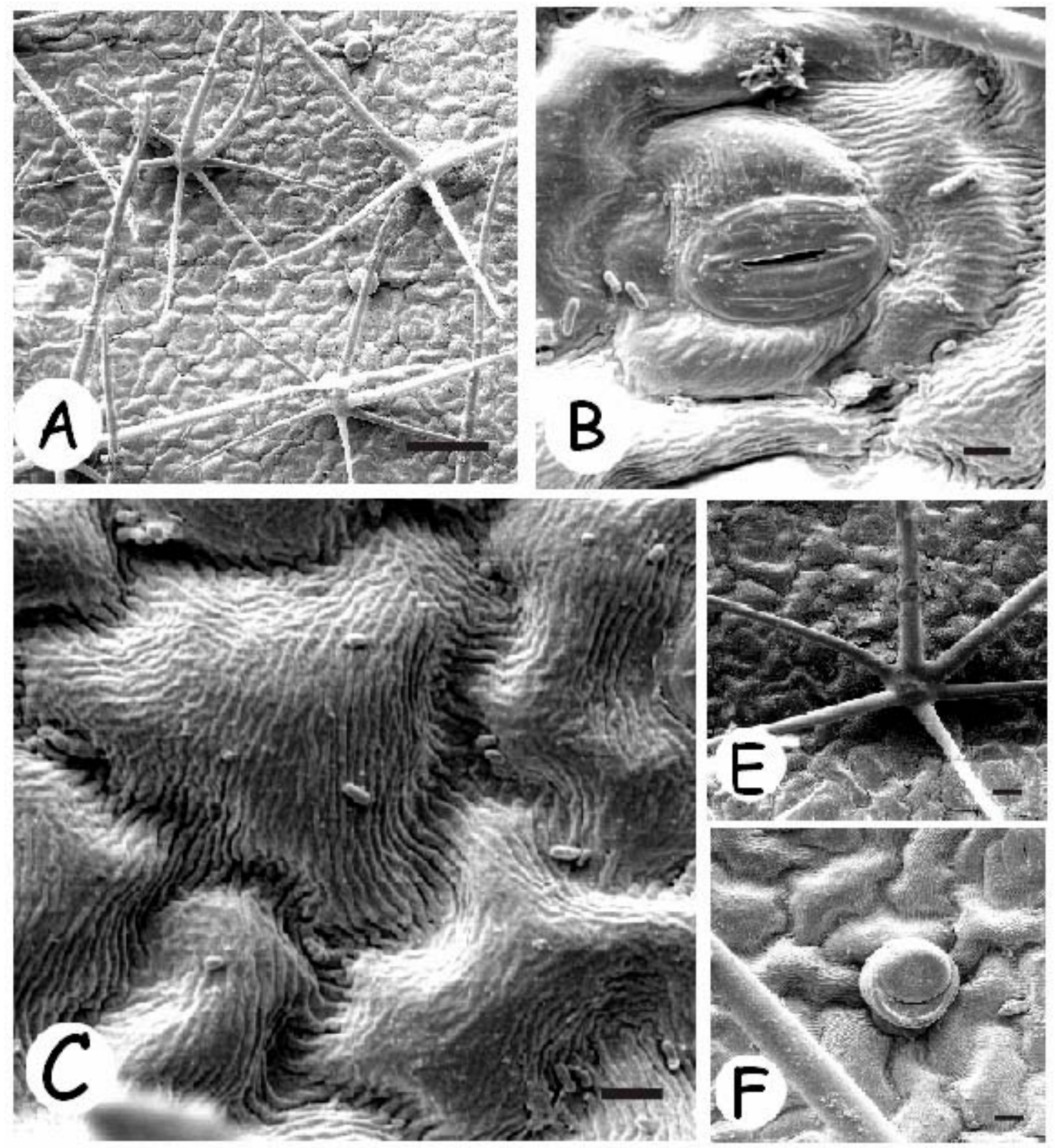

Figura 21 - Superfície foliar adaxial de Sida glaziovii (guanxuma-branca). A: Visão geral da superfície foliar (200x); B: Detalhe do estômato (2000x); C: Detalhe da superfície das células epidérmicas (2000x); E: Detalhe do tricoma estelar (500x); F: Detalhe do tricoma glandular (2000x). Barras: $100 \mu \mathrm{m}, 5 \mu \mathrm{m}, 5 \mu \mathrm{m}, 5 \mu \mathrm{m}$ e $20 \mu \mathrm{m}$, respectivamente 


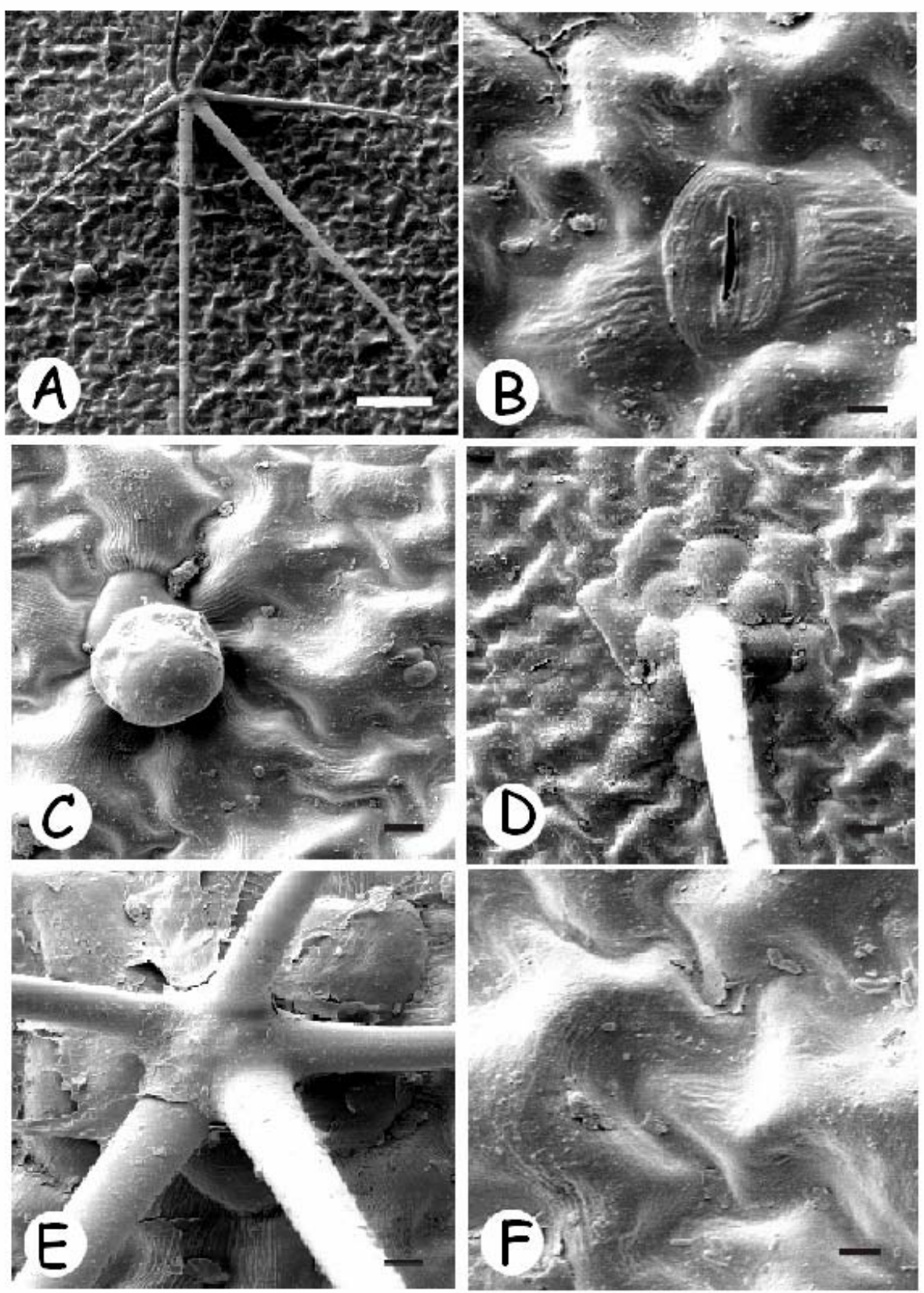

Figura 22 - Superfície foliar abaxial de Sida glaziovii (guanxuma-branca). A: Visão geral da superfície foliar (200x); B: Detalhe do estômato (2000x); C: Detalhe do tricoma glandular (1000x); D: Detalhe do tricoma unicelular (500x); E: Detalhe do tricoma estelar (1000x); F: Detalhe das células epidérmicas (2000x). Barras: $100 \mu \mathrm{m}, 5 \mu \mathrm{m}, 10 \mu \mathrm{m}, 20 \mu \mathrm{m}, 10 \mu \mathrm{m}$ e $5 \mu \mathrm{m}$, respectivamente 


\subsection{Conclusões}

Para as condições em que esta pesquisa foi realizada, pôde-se concluir:

a) As espécies E. heterophylla, S. rhombifolia e S. glaziovii apresentaram maior densidade estomática na superfície abaxial.

b) As densidades estomáticas nas superfícies adaxiais das espécies $S$. rhombifolia e S. glaziovii não diferiram estatisticamente entre si, as superfícies abaxiais apresentaram o mesmo comportamento.

c) A espécie E. heterophylla apresentou depósito de ceras epicuticulares na forma de cristais em ambas superfícies foliares e as espécies do gênero Sida avaliadas apresentaram depósito de ceras epicuticulares na forma de estrias.

d) S. rhombifolia apresentou tricomas estelares na superfície abaxial e $S$. glaziovii apresentou tricomas estelares em ambas superfícies foliares. 


\section{ESTUDO DA ABSORÇÃO E TRANSLOCAÇÃO DE 2,4-D EM PLANTAS DE Memora peregrina}

\section{Resumo}

O objetivo desta pesquisa foi avaliar a absorção e translocação do herbicida 2,4-D em plantas de Memora peregrina (Miers) Sandwith. A absorção e translocação do herbicida 2,4-D radiomarcado foram analisadas com o 2,4-D na formulação comercial DMA 806 BR e também na mistura do 2,4-D (DMA 806 BR) associado ao herbicida

picloram (produto comercial Padron). Foram determinadas as quantidades de radioatividade da lavagem das folhas tratadas em metanol e em clorofórmio nos intervalos de tempo de 1, 2, 4, 8, 24 e 48 horas após as aplicações do produto radiomarcado. Para a avaliação da translocação, nos intervalos de tempo determinados, a planta foi secionada na base do caule, obtendo-se as seguintes partes: raiz, caule, folha tratada, folhas acima da tratada, folhas abaixo da tratada e folha oposta à folha tratada. Estas partes foram secas, moídas, queimadas e determinadas as radioatividades. $\mathrm{Na}$ primeira hora após a aplicação, a absorção do 2,4-D associado ao picloram foi 9,63\% e quando o 2,4-D foi aplicado sozinho, foi de 8,22\%. A absorção 48 horas após a aplicação do 2,4-D associado ao picloram foi de 24,26\% e 23,81\% quando o 2,4-D foi aplicado sozinho. Quando o 2,4-D foi aplicado 48 horas após a aplicação 98,44\% do herbicida radioativo estava na folha tratada, e quando usado a associação com o picloram $99,50 \%$ do herbicida radioativo estava na folha tratada. Nas outras partes da planta traços do herbicida radioativo foram encontrados, concluindo-se que a translocação do herbicida 2,4-D foi considerada insignificante em plantas de $M$. peregrina. Estes resultados puderam explicar o ineficiente controle obtido com este herbicida nesta planta daninha em condições de campo. 


\section{STUDY OF THE ABSORPTION AND TRANSLOCATION OF 2,4-D IN PLANTS OF Memora peregrina}

\section{Summary}

The objective of this research was to evaluate the absorption and translocation of the herbicide 2,4-D in plants of Memora peregrina (Miers) Sandwith. The absorption and translocation of radiolabelled 2,4-D herbicide was studied using 2,4D alone (DMA 806 BR) and also in mixture of 2,4-D (DMA 806 BR) associated with the herbicide picloram (in the commercial product Padron). The levels of radioactivity on the leaves treated were determined in samples obtained by washing with methanol and chloroform in different times after application of radiolabelled formulation $(1,2,4$, 8, 24 and 48 hours). The translocation was evaluated by cutting the plants in following parts: root, stem, treated leaf, leaves above the treated leaf, leaves below the treated leaf and leaf opposite of the treated leaf. These parts were weighted, dried, ground, burned and their radioactivity was determined. In the first hour after spraying, the absorption of the 2,4-D associated with picloram was $9.63 \%$ and when the 2,4-D was applied alone, it was $8.22 \%$. The absorption 48 hours after spraying of the 2,4-D associated with picloram was $24.26 \%$ and $23.81 \%$ when the 2,4-D (DMA 806 BR) was applied alone. When used the 2,4-D after 48 hours were found $98.44 \%$ of the radioactive herbicide in the treated leaf and when used the association with picloram were found $99.50 \%$ in the treated leaf. In the other parts of the plant traces of the herbicide radioactive were found, as a consequence, the translocation of the herbicide 2,4-D was considered insignificant in plants of $M$. peregrina. These results could explain the inefficient control obtained with this herbicide in this weed. 


\subsection{Introdução}

As plantas daninhas competem com as plantas cultivadas por água, luz e nutrientes, e em certas ocasiões são tóxicas aos animais, como no caso de algumas invasoras de pastagens, além de causar interferências como a alelopatia. As plantas daninhas provocam limitações ao desenvolvimento das plantas cultivadas, tanto em culturas anuais e perenes como em pastagens.

Memora peregrina (Miers) Sandwith é uma planta perene, ereta de ramos escandentes, lenhosas, pouca ramificada, com folhas de textura coriácea e áspera, de 80$140 \mathrm{~cm}$ de altura, nativa do Brasil. Propaga-se por sementes, contudo expande-se numa

grande reboleira através de rizomas. É uma planta típica dos cerrados brasileiros que se perpetua nestas áreas após a sua transformação em pastagens, tornando-se uma planta indesejável. Formam grandes reboleiras de difícil controle e ou erradicação (Lorenzi, 2000).

As plantas daninhas são plantas que ocorrem em locais não desejados pelo homem. Elas ocorrem em culturas perenes e anuais, como em pastagens, ou seja, em locais utilizados pelo homem para a produção agropecuária no sustento da humanidade. Na agricultura, as plantas daninhas reduzem a produção de alimentos e na pecuária as plantas daninhas interferem com as forrageiras reduzindo a capacidade de lotação das pastagens, além de algumas delas causarem ferimentos aos animais e serem plantas tóxicas (Victoria Filho, 1986).

Nunes (1999) alerta que a infestação da ciganinha (Memora peregrina) já inviabilizou várias áreas de pastagens ou mesmo propriedades, por causa dos altos níveis de infestação e elevados custos para erradicá-la. Ainda destaca, que esta alta capacidade de infestação deve-se a eficientes formas de dispersão e propagação vegetativa, além das sementes aladas, possuem caules subterrâneos com grande capacidade de rebrote.

Para o sucesso de pulverizações de agroquímicos, é fundamental o conhecimento das influências intrínsecas às plantas (disposição das folhas, $\mathrm{pH}$ foliar, ceras epicuticulares, estômatos, tricomas, etc) e influências extrínsecas, como características 
físico-químicas da solução de pulverização (tensão superficial, área de molhamento, pH da solução, tipo de formulação, etc) (Mendonça, 2000a).

Segundo Hess (1997), dentre os fatores que influenciam a quantidade e distribuição de herbicidas na superfície foliar, afetando a absorção, estão: a) tensão superficial da solução de pulverização; b). a molhabilidade da superfície foliar que depende da quantidade de cera cuticular e estrutura física das ceras e dos tricomas da superfície foliar; c) a orientação da folha com respeito à chegada das gotas de pulverização; d) o total de área foliar por planta (probabilidade de interceptar a gota de pulverização).

Na aplicação de agroquímicos, Bukovac \& Petracek (1993) acreditam que a penetração foliar começa quando a solução é retida pela superfície da planta. Esse é um processo contínuo, consistindo de três etapas: sorção, difusão e desorção. A sorção consiste na distribuição do ingrediente ativo entre a solução aquosa de pulverização e a cutícula. $\mathrm{O}$ soluto é então difundido através da cutícula e, quando as moléculas chegam na interface da superfície cutícula/parede celular, elas são desorvidas da cutícula no apoplasto aquoso. Para simplificar pode-se exemplificar a penetração cuticular como a difusão do soluto de um doador aquoso (solução de pulverização), através da cutícula (membrana), em um receptor aquoso (apoplasto). Segundo Schreiber \& Schönherr (1992), o equilíbrio desse processo estabiliza-se em 30 minutos; após esse período, a absorção representa a penetração da molécula para o interior das células foliares (simplasto). Ainda, outro determinante da permeabilidade é a baixa mobilidade dos solutos nas ceras epicuticulares.

Segundo Wirth et al.(1991), a aplicação do ingrediente ativo começa com a preparação da solução de pulverização e é seguida pela pulverização, trajetória e impacto na superfície da folha. Salienta que para obter a máxima eficácia na aplicação cada passo deve ser otimizado. Segundo Kirkwood (1999), as propriedades físico-químicas da cutícula influenciam o comportamento da gota de pulverização, podendo afetar a taxa e eficiência da penetração cuticular. A difusão do ingrediente ativo é influenciada por suas características químicas, como a solubilidade, indicada pelos coeficientes de partição octanol/água $\left(\mathrm{K}_{\mathrm{oa}}\right)$ e 
cutícula/água $\left(\mathrm{K}_{\mathrm{ca}}\right)$. A remoção das ceras promove um aumento na sorção, pelo fato de tornar acessíveis sítios adicionais à sorção (Bukovac \& Petracek, 1993).

Os produtos fitossanitários geralmente devem ser depositados nas superfícies de folhas, ramos e frutos e, para uma boa compatibilidade física entre essas superfícies e as caldas de pulverização, deve-se levar em consideração a espécie da planta, a idade dos órgãos e as condições ambientais (Kissmann, 1997).

A absorção foliar de herbicidas é um processo complexo, envolvendo a passagem das moléculas de herbicida da superfície externa da folha, através da cutícula, para o interior do tecido. A passagem das moléculas de herbicida para dentro da folha é função da natureza química e física da cutícula, as propriedades dos herbicidas, a formulação de ingrediente ativo, o ambiente em que a folha desenvolveu-se e o ambiente em que ocorreu a absorção. Considerar todas essas variáveis e combiná-las em um modelo geral de absorção de herbicidas seria ideal, no entanto existem muitos fatores que governam a absorção de herbicidas, e que cada combinação herbicida / planta / formulação / ambiente tem suas próprias características (Devine et al., 1993).

O processo de absorção do ingrediente ativo inicia-se logo após o contato da solução de pulverização com a superfície foliar. Observações obtidas por Mendonça (2000b), mostraram que, em 20 minutos após a pulverização, 10,72\% do herbicida propanil pulverizado sobre folhas de arroz já havia sido absorvido neste curto período. No entanto, após 8 horas da aplicação apenas 16,63\% do herbicida havia sido absorvido, observando que o incremento na absorção foi pequeno em função do tempo.

A recomendação de Nunes (1999) quanto ao controle da ciganinha (Memora peregrina) é que seja de modo amplo, ou seja, envolvendo toda uma região de forma integrada, incluindo medidas preventivas, métodos químicos e mecânicos associados, aliados a práticas culturais e de manejo que favoreçam o desenvolvimento da forrageira desejada. O método de controle químico mais eficaz foi por aplicações no toco imediatamente após o corte com enxadão, com pulverizador costal utilizando o herbicida picloram (Padron) nas concentrações de 1 a 2 \%. Entretanto, a viabilidade e a eficiência do controle estão diretamente relacionadas com o grau de infestação, com a 
aplicação do produto nas doses recomendadas e com a adoção de práticas que favoreçam a recuperação da pastagem.

Várias pesquisas têm sido feitas envolvendo a absorção e translocação de 2,4-D em diferentes espécies vegetais como Silene vulgaris (Moench) Garcke (Wall et al., 1991), Sisymbrium orientale Torn. (Wolf et al. 1992), Apocynum cannabinum L. (Schultz \& Burnside, 1980; Wyrill \& Burnside, 1976) e Asclepias syriaca L. (Wyrill \& Burnside, 1976). Porém, muitos autores também avaliaram a absorção e translocação de 2,4-D em associação com picloram no controle de Euphorbia esula L. (Nelson \& Lym, 2003; Thompson et al., 1996; Lym \& Moxness, 1989) e de Isocoma drummondii (T. \& G.) Greene (Mayeux \& Scifres, 1980). A associação do herbicida 2, 4 -D com o picloram tem sido usado com grande sucesso como método de controle químico para estas espécies.

A adição de picloram formulado (Padron) teve o objetivo para avaliar interações na absorção e translocação com o herbicida ${ }^{14} \mathrm{C} 2,4-\mathrm{D}$. O aumento do picloram não metabolizado no sistema radicular de Euphorbia esula quando o 2, 4 - D foi aplicado com picloram comparado com a aplicação do picloram sozinho, pode ser a razão para o aumento no controle desta planta daninha (Lym \& Moxness, 1989).

O objetivo desta pesquisa foi avaliar a absorção e translocação do ${ }^{14} \mathrm{C} 2,4-\mathrm{D}$ adicionado ao 2, 4-D (produto comercial DMA 806 BR) e na mistura de 2, 4-D mais picloram (DMA 806 BR mais Padron) em plantas de M. peregrina (ciganinha).

\subsection{Material e Métodos}

Esta pesquisa foi conduzida no Departamento de Produção Vegetal da Escola Superior de Agricultura "Luiz de Queiroz" da USP e no Laboratório de Ecotoxicologia do Centro de Energia Nuclear na Agricultura (CENA/USP).

As plantas de Memora peregrina foram obtidas a partir de mudas advindas de sementes desenvolvidas em Campo Grande-MS. As mudas foram transplantadas em vasos de capacidade de 5000 mL conduzidas em casa-de-vegetação do Departamento de 
Produção Vegetal em Piracicaba-SP. Após um ano e três meses as plantas estavam com aproximadamente $30 \mathrm{~cm}$ altura, estádio no qual foi realizada a pesquisa.

O herbicida 2,4-D radiomarcado utilizado apresentou atividade específica de $15,0 \mathrm{mCi} \mathrm{mmol}{ }^{-1}$. O tratamento 1 consistiu do ${ }^{14} \mathrm{C} 2,4-\mathrm{D}$ adicionado à formulação DMA $806 \mathrm{Br}$ do herbicida 2,4-D, na dose de 1,34 kg e.a. em $100 \mathrm{~L}$ de água. O tratamento 2 consistiu do ${ }^{14} \mathrm{C}$ 2,4-D adicionado à mistura das formulações DMA 806 BR e Padron, do herbicida 2,4-D e picloram, respectivamente, sendo o 2,4-D na dose de 1,34 kg e.a. em 100 L e o picloram na dose de 0,48 kg e.a. para 100 L de água. Esta forma de preparação da solução do herbicida radioativo com a formulação comercial foi utilizada para que os surfatantes presentes nas formulações comerciais atuassem durante o processo de absorção. A calda de pulverização dos dois tratamentos (2,4-D e 2,4-D+picloram) sem o herbicida radioativo foi preparada equivalente à dose utilizada nos tratamentos 1 e 2 .

A folha que seria tratada com formulação radiomarcada foi coberta com papel de alumínio e as outras partes das plantas foram pulverizadas com a calda sem a adição do herbicida radiomarcado, ou seja, nos tratamentos 2,4-D (DMA 806 BR) e 2,4D+picloram (DMA 806 BR + Padron). Imediatamente após esta aplicação, o papel de alumínio foi removido e a calda de pulverização com a herbicida radiomarcado de cada tratamento foi aplicada. A quantidade de radioatividade foi determinada em seis períodos após a aplicação (1, 2, 4, 8, 24 e 48 horas). Após cada período, a superfície foliar tratada com formulação radiomarcada foi lavada com 1,5 mL de metanol para remover o herbicida não absorvido e depois foi lavado com 1,5 mL de clorofórmio para extrair o herbicida preso às ceras epicuticulares. Então, o produto não absorvido, o produto ligado nas ceras epicuticulares e o produto absorvido foram quantificados. As amostras com metanol e clorofórmio foram evaporadas com nitrogênio e $15 \mathrm{~mL}$ da solução cintiladora foi adicionada em cada amostra.

As plantas foram separadas em diferentes partes para determinação da translocação, obtendo as seguintes partes: raiz, caule, folha tratada com a formulação radiomarcada, folhas acima da folha tratada, folhas abaixo da folha tratada e folha oposta a folha tratada. As raízes foram lavadas com água para remover o solo. As partes da planta 
foram pesadas, secas e moídas. Uma alíquota da amostra foi queimada em oxidador biológico, foi adicionada a solução cintiladora e a radioatividade foi determinada usando Analisador de Cintilação Líquida. A absorção foi expressa em porcentagem do total de ${ }^{14} \mathrm{C}$ 2,4-D aplicado, e calculado a radiatividade recuperada na lavagem das folhas com metanol e clorofórmio e nas partes da planta que foram queimadas. A translocação foi expressa como a porcentagem do herbicida ${ }^{14} \mathrm{C} 2,4-\mathrm{D}$ absorvido.

Três repetições foram utilizadas para cada período avaliado nos estudos de absorção e translocação. A diferença mínima significativa (DMS) foi determinada pelo teste de Tukey de comparação de médias ao nível de 5 \% de probabilidade.

\subsection{Resultados e Discussão}

Na Tabela 19 estão apresentadas as porcentagens do herbicida ${ }^{14} \mathrm{C}$ 2,4-D ligado as ceras epicuticulares em relação ao aplicado. Uma e duas horas após a aplicação, a retenção do herbicida ${ }^{14} \mathrm{C}$ 2,4-D foi menor no tratamento com 2, 4-D do que no tratamento com 2, 4-D mais picloram, porém nos outros períodos avaliados, a retenção do ${ }^{14} \mathrm{C} 2,4$-D foi estabilizada e não houve diferença estatística entre os tratamentos. As ceras mostraram uma grande capacidade em reter este herbicida, tornando claro que a capacidade de herbicidas em ligar-se nas ceras epicuticulares depende das características da formulação comercial, principalmente da presença de surfactantes. As folhas de Populus baesamifera após terem sido mergulhadas em clorofórmio por 40 a 60 segundos apresentaram um incremento na absorção do picloram (de 7\% para 20\%) e do 2,4-D (de 8\% para 29\%), devido ao efeito da extração das ceras epicuticulares. Enfatizando a importância das ceras cuticulares como barreiras para entrada de herbicida (Sharma \& Born, 1970).

As curvas de absorção do herbicida ${ }^{14} \mathrm{C}$ 2,4-D nos tratamento com 2, 4-D sozinho e em mistura com picloram apresentaram o mesmo comportamento (Figura 23). As porcentagens de absorção do herbicida ${ }^{14} \mathrm{C}$ 2,4-D nos tratamentos avaliados não apresentaram diferenças estatísticas determinada pelo valor da diferença mínima significativa (Tabela 20). Na primeira hora após a aplicação a porcentagem de absorção da 
mistura foi 9,63 \% e 8,22 \% quando o 2, 4-D foi usado sozinho. Após 48 horas da aplicação do herbicida radiomarcado a absorção foi de 24,26\% no tratamento da mistura 2, 4-D mais picloram e 23,81 \% com o 2, 4-D sozinho. A porcentagem de 2,4-D absorvida por Isocoma drummondii foi 12 \% em 48 horas após a aplicação na planta (Mayeux \& Scifres, 1980), valor este menor do que o encontrado nesta pesquisa. A absorção do herbicida propanil em plantas de arroz foi 10,72 \% em 20 minutos após a aplicação. Porém, somente 16,63\% do herbicida aplicado foi absorvido em 8 horas após a aplicação (Mendonça, 2000b). A adição de picloram à formulação radiomarcada de ${ }^{14} \mathrm{C}$ 2,4-D reduziu a porcentagem de absorção de 43 para 29\%, quando se comparou com a aplicação de ${ }^{14} \mathrm{C}$ 2,4-D sozinho (Nelson \& Lym, 2003). O mesmo comportamento não foi observado nesta pesquisa, onde a adição de picloram ao ${ }^{14} \mathrm{C}$ 2,4-D não interferiu na absorção (Tabela 2). Em plantas de Euphorbia esula a adição de picloram ao ${ }^{14} \mathrm{C}$ 2,4-D diminuiu a absorção de 34 para 24\%, contudo a porcentagem de translocação não foi afetada (Lym \& Moxness, 1989).

Tabela 19. Porcentagens do herbicida ${ }^{14} \mathrm{C}$ 2,4-D extraído pelo clorofórmio das ceras epicuticulares de Memora peregrina. Piracicaba, SP, 2004

\begin{tabular}{cccc}
\hline & \multicolumn{3}{c}{ Porcentagem do ${ }^{14} \mathrm{C} 2,4-\mathrm{D}$ aplicado } \\
Tempo (horas) & $2,4-\mathrm{D}$ & $2,4-\mathrm{D}+$ picloram & dms $^{1}$ \\
\hline 1 & 0,93 & 6,47 & 3,07 \\
2 & 3,04 & 7,75 & 3,17 \\
4 & 6,62 & 6,48 & 2,67 \\
8 & 5,69 & 6,25 & 3,44 \\
24 & 6,07 & 9,44 & 5,48 \\
48 & 8,86 & 6,78 & 2,98 \\
\hline
\end{tabular}

\footnotetext{
${ }^{1}$ dms: diferença mínima significativa entre médias usando teste de Tukey a 5 \% de significância.
} 


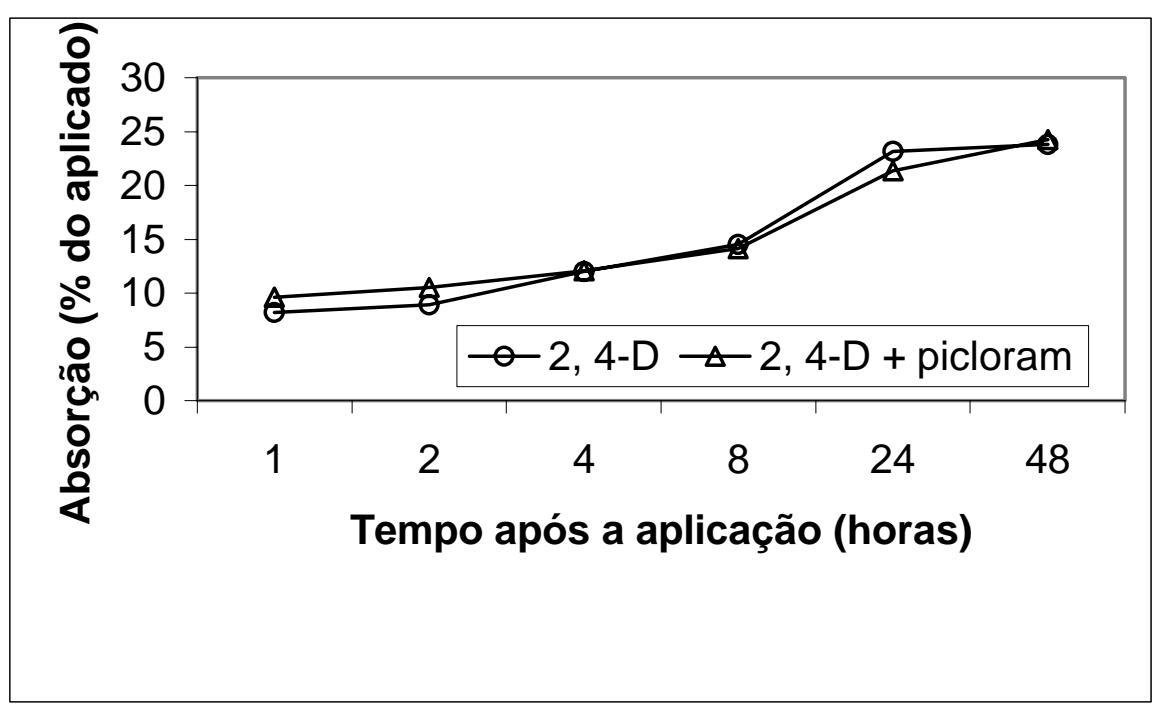

Figura 23 - Porcentagem de absorção de ${ }^{14} \mathrm{C}$ 2, 4-D em plantas de Memora peregrina

Tabela 20. Porcentagens de absorção de ${ }^{14} \mathrm{C} 2$, 4 - D em Memora peregrina. Piracicaba, SP, 2004

\begin{tabular}{cccc}
\hline & \multicolumn{3}{c}{ Porcentagem do ${ }^{14} \mathrm{C} 2,4-\mathrm{D}$ aplicado } \\
Tempo (horas) & $2,4-\mathrm{D}$ & $2,4-\mathrm{D}+$ picloram & $\mathrm{dms}^{1}$ \\
\hline 1 & 8,22 & 9,63 & 9,16 \\
2 & 8,92 & 10,54 & 11,24 \\
4 & 12,01 & 12,07 & 5,69 \\
8 & 14,49 & 14,13 & 10,93 \\
24 & 23,17 & 21,36 & 19,05 \\
48 & 23,81 & 24,26 & 13,54
\end{tabular}

${ }^{1}$ dms: diferença mínima significativa entre médias usando teste de Tukey a 5 \% de significância.

A translocação foi determinada com base na quantidade de ${ }^{14} \mathrm{C} 2,4-\mathrm{D}$ absorvida pela planta. A Tabela 21 são apresentados os resultados das porcentagens de translocação nas diferentes partes da planta 48 horas após a aplicação, sendo que 98,44\% do ${ }^{14} \mathrm{C} 2$,4-D ficaram na folha tratada quando o 2, 4-D foi usado e 99,50\% ficaram na folha 
tratada quando a mistura de 2, 4-D mais piloram foi usada. A translocação, ou a porcentagem do herbicida ${ }^{14} \mathrm{C} 2,4-\mathrm{D}$ que saiu da folha tratada foi $1,56 \%$ no tratamento com 2, 4-D sozinho e $0,50 \%$ quando a mistura de 2, 4-D mais picloram foi usada. A quantidade do herbicida ${ }^{14} \mathrm{C}$ 2,4-D translocada foi pequena, podendo ser considerada insignificante em plantas de $M$. peregrina. A translocação do herbicida ${ }^{14} \mathrm{C}$ CGA 3626622 também foi pequena, chegando a 95\% do total absorvido ter permanecido na folha tratada em plantas de algodão (Richardson et al., 2003). Morrison et al. (1995) também observou que 98,1\% do herbicida picloram absorvido permaneceu nas folhas tratadas de Acroptilon repens, em condições de -1,42 MPa do potencial da água. E estes autores não recomendam controlar estas plantas em condições de estresse hídrico.

Tabela 21. Translocação de ${ }^{14} \mathrm{C}$ 2,4-D absorvido em plantas de Memora peregrina, 48 horas após a aplicação. Piracicaba, SP, 2004.

\begin{tabular}{cccc}
\hline & \multicolumn{3}{c}{ Porcentagem do ${ }^{14} \mathrm{C} 2,4-\mathrm{D}$ absorvido } \\
Tempo (horas) & $2,4-\mathrm{D}$ & $2,4-\mathrm{D}+$ picloram & $\mathrm{dms}^{1}$ \\
\hline Folha tratada & 98,44 & 99,50 & 2,45 \\
Folha oposta a folha tratada & 0,12 & 0,01 & - \\
Folhas acima a folha tratada & 0,14 & 0,37 & - \\
Folhas abaixo a folha tratada & 0,03 & 0,01 & - \\
Caules & 0,99 & 0,09 & - \\
Raízes & 0,28 & 0,02 & 2,44 \\
\hline Total translocado & 1,56 & 0,50 &
\end{tabular}

\footnotetext{
${ }^{1}$ dms: diferença mínima significativa entre médias usando teste de Tukey a 5 \% de significância.
} 


\subsection{Conclusões}

Para as condições em que esta pesquisa foi realizada, pôde-se concluir:

a) A absorção do herbicida ${ }^{14} \mathrm{C}$ 2,4-D nos tratamentos com 2, 4-D e na mistura 2, 4-D mais picloram apresentou o mesmo comportamento em plantas de $M$. peregrina.

b) A translocação do herbicida ${ }^{14} \mathrm{C}$ 2,4-D foi insignificante em plantas de M. peregrina.

Estes resultados podem explicar o ineficiente controle químico desta planta com o herbicida 2,4-D. Ressaltando ainda, que esta pesquisa analisou o herbicida 2,4-D radiomarcado, e que os resultados de absorção e translocação não servem para o herbicida picloram, já que não foi realizado o estudo da absorção e translocação de seu produto radiomarcado. 


\section{CONCLUSÕES GERAIS}

Para as condições em que esta pesquisa foi realizada, pôde-se concluir:

A) Quanto às características das superfícies foliares das plantas daninhas estudadas:

a) Todas as espécies daninhas avaliadas ( $P$. fuchsiaefolia, $V$. polyanthes, $V$. westiniana, M. peregrina, T. stans, I. grandifolia, I. purpurea, E. heterophylla, S. rhombifolia e S. glaziovii) apresentaram maior densidade estomática na superfície abaxial. A espécie $M$. peregrina apresentou a maior densidade estomática na superfície abaxial, porém foram ausentes na sua superfície adaxial.

b) Todas as espécies estudadas apresentaram maior porcentagem de compostos polares. As espécies $E$.heterophylla, $M$. peregrina e T. stans apresentaram os maiores valores das porcentagens de compostos apolares (48,9\%, 41,5\% e 40,5\%, respectivamente).

c) As espécies $P$. fuchsiaefolia, $V$. polyanthes, $V$. westiniana e $T$. stans apresentaram depósitos de ceras amorfos em ambas superfícies foliares.

d) Nas superfícies foliares de folhas velhas de $M$. peregrina foi observado espesso depósito de ceras epicuticulares.

e) As espécies I. grandifolia e I. purpurea apresentaram depósito de ceras estriados na superfície adaxial. As superfícies foliares das espécies do gênero Sida também apresentaram depósito de ceras na forma de estrias.

f) Dentre as espécies avaliadas, somente E. heterophylla apresentou ceras epicuticulares na forma de cristais em ambas superfícies foliares. 
B) Quanto ao estudo da absorção e translocação de 2,4-D em Memora peregrina:

a) As absorções do herbicida ${ }^{14} \mathrm{C}$ 2,4-D nos tratamentos com 2, 4-D e na mistura 2, 4-D mais picloram apresentaram o mesmo comportamento em plantas de $M$. peregrina.

b) A translocação do herbicida ${ }^{14} \mathrm{C}$ 2,4-D foi insignificante em plantas de M. peregrina. 


\section{REFERÊNCIAS BIBLIOGRÁFICAS}

ALBERT, L.H.B.; VICTORIA FILHO, R. Micromorfologia foliar de espécies de Sida spp. (guanxumas). Planta Daninha, v.20, n. 3, p.337-342, 2002.

ALBERT, L.H.B. Características morfológicas da cutícula foliar e efeitos de adjuvantes no controle químico de três espécies de guanxumas. Piracicaba, 2000. 94 p. Dissertação (Mestrado) - Escola Superior de Agricultura "Luiz de Queiroz”, Universidade de São Paulo.

BAKER, E.A. Chemistry and morphology of epicuticular waxes. In: CUTLER, D.F.; ALVIN, K.L.; PRICE, C.E. (Ed.). The plant cuticle. London: Academic Press, 1991, cap.8, p.139-165.

BUKOVAC, M.J.; PETRACEK, P.D. Characterizing pesticide and surfactant penetration with isolated plant cuticle. Pesticide Science, v.37, n.2, p.179-194, 1993.

DEVINE, M.D.; DUKE, S.O.; FEDTKE, C. Foliar absorption of herbicides. In: DEVINE, M.D.; DUKE, S.O.; FEDTKE, C. (Ed.). Physiology of herbicide action. New Jersey: Englewwod Cliffs, 1993. cap.11, p.29-52.

DIAS, N.M.P.; REGITANO, J.B.; CHRISTOFFOLETI, P.J.; TORNISIELO, V.L. Absorção e translocação do herbicida diuron por espécies suscetível e tolerante de capim-colchão (Digitaria spp.). Planta Daninha, v.21, n.2, p.293-300, 2003. 
EGLINTON, G.; HAMILTON, R.J. Leaf epicuticular waxes. Science, v.156, n. 4, p.1322-35, 1967.

FAHN, A. Plant Anatomy. Oxford: Pergamon Press, 1990. 588 p.

FERREIRA, E.A.; PROCÓPIO, S.O.; SILVA, E.A.M.; SILVA, A.A.;RUFINO, R.J.N. Estudos anatômicos de folhas de plantas daninhas. I Nicandra physaloides, Solanum viarum, Solanum americanum e Raphanus raphanistrum. Planta Daninha, v. 20, n.2, p.159-168, 2002.

FERREIRA, E.A.; PROCÓPIO, S.O.; SILVA, E.A.M.; SILVA, A.A.;RUFINO, R.J.N. Estudos anatômicos de folhas de espécies de plantas daninhas de grande ocorrência no Brasil. IV Amaranthus deflexus, Amaranthus spinosus, Alternanthera tenella e Euphorbia heterophylla. Planta Daninha, v. 21, n.2, p.263-271, 2003.

HARR, J.; GUGGENHEIM, R.; SCHULKE, G.; FALK, R. H. The leaf surface of major weeds. Switzerland: Sandoz Agro, 1991. 134p.

HESS, F.D. Absorption. In: WELLER, S.C. (Coord.) Herbicide action course 1997. West Lafayette: Purdue University, 1997. cap.2, p.15-37.

HESS, F.D.; FALK, R.H. Herbicide deposition on leaf surfaces. Weed Science, v.38, n.3, p.280-288, 1990.

KIRKWOOD, R.C., Recent developments in our understanding of the plant cuticle as a barrier to the foliar uptake of pesticides. Pesticide Science, v.55, n.1, p.69-77, 1999. 
KISSMANN, K.G. Adjuvantes para caldas de produtos fitossanitários. In: CONGRESSO BRASILEIRO DA CIÊNCIA DAS PLANTAS DANINHAS 21., Caxambu, 1997. Palestras. Caxambu: Sociedade Brasileira da Ciência das Plantas Daninhas, 1997. p.61-77.

KISSMANN, K.G.; GROTH, D. Plantas infestantes e nocivas. 2.ed. São Paulo: Basf, 1999. 978p. 2v.

KISSMANN, K.G.; GROTH, D. Plantas infestantes e nocivas. 2.ed. São Paulo: Basf, 2000. 722p. 3v.

KITAJIMA, E.W.; LEITE, B. Curso introdutório de microscopia eletrônica de varredura. 2.ed. Piracicaba: Universidade de São Paulo, 1999. 46 p.

LORENZI, H. Plantas daninhas do Brasil: terrestres, aquáticas, parasitas e tóxicas. 3.ed. Nova Odessa: Instituto Plantarum, 2000. 608 p.

LYM, R.G.; MOXNESS, K.D. Absorption, translocation, and metabolism of picloram and 2,4-D in leafy spurge (Euphorbia esula)..Weed Science, v.37, n.4, p.498-502, 1989.

MAUSETH, J.D. Epidermis. In: MAUSETH, J.D. Plant Anatomy. Califórnia: Cummings Publishin, 1988. cap.10, p.167-198.

MAYEUX JUNIOR., H.S.; SCIFRES, C.J. Foliar uptake and transport of 2, 4-D and picloram by Drummond's goldenweed (Isocoma drummondii). Weed Science, v.28, n.6, p.678-682, 1980.

MCWHORTER, C.G.; OUZTS, C. Leaf surface morphology of Erythroxylum sp. and droplet spread. Weed Science, v.42, n.1, p.18-26, 1994. 
MCWHORTER, C.G.; OUZTS, C.; PAUL, R.N. Micromorphology of johnsongrass (Sorghum halepense) leaves. Weed Science, v.41, n.4, p.583-589, 1993.

MENDONÇA, C.G. Algumas características da superfície foliar de diversas plantas daninhas monocotiledôneas. Botucatu, 2000a. 89p. Dissertação (M.S.) - Faculdade de Ciências Agronômicas, Universidade Estadual Paulista “Júlio de Mesquita Filho”.

MENDONÇA, C.G. Comportamento do propanil e eficácia do anidrido naftálico como protetor de herbicidas para arroz. Botucatu, 2000b. 70p. Dissertação (M.S.) Faculdade de Ciências Agronômicas, Universidade Estadual Paulista “Júlio de Mesquita Filho”.

MENDONÇA, C.G. Efeitos de óleos minerais e vegetais nas propriedades físicoquímicas das caldas de pulverização e suas interações com superfícies foliares. Botucatu, 2003. 96p. Tese(Doutorado) - Faculdade de Ciências Agronômicas, Universidade Estadual Paulista “Júlio de Mesquita Filho”.

METCALFE, C.R.;CHALK, L. Anatomy of the dicotyledons. In: METCALFE, C.R.;CHALK, L. The plant surface (mainly leaf). 2.ed. Oxford: Clarendon Press, 1979. cap.10, p.87-165.

MONQUERO, P.A. Dinâmica populacional e mecanismos de tolerância de espécies de plantas daninhas ao herbicida glyphosate. Piracicaba, 2003. 99p. Tese(Doutorado) Escola Superior de Agricultura “Luiz de Queiroz”, Universidade de São Paulo.

MORRISON, R.G.; LOWNDS, N.K; STERLING, T.M. Picloram uptake, translocation, and efficacy in relation to water status of Russian Knapweed (Acroptilon repens). Weed Science, v. 43, n.1, p.34-39, 1995. 
NELSON, J.A.; LYM, R.G. Interactive effects of Aphthona nigriscutis and picloram plus 2, 4 - D in leafy spurge (Euphorbia esula). Weed Science, v.51, n.1, p.118-124, 2003.

NUNES, S.G. Ciganinha - planta invasora de pastagem, alerta geral. Campo Grande: Embrapa Gado de Corte, 1999. 4p.

PROCÓPIO, S.O.; FERREIRA, E.A.; SILVA, E.A.M.; SILVA, A.A.;RUFINO, R.J.N. Estudos anatômicos de folhas de espécies de plantas daninhas de grande ocorrência no Brasil. V Leonurus sibiricus, Leonotis neperaefolia, Plantago tomentosa e Sida glaziovii. Planta Daninha, v. 21, n.3, p.403-412, 2003.

PROCÓPIO, S.O.; FERREIRA, E.A.; SILVA, E.A.M.; SILVA, A.A.;RUFINO, R.J.N.; SANTOS, J.B. Estudos anatômicos de folhas de espécies de plantas daninhas de grande ocorrência no Brasil. III - Galinsoga parviflora, Crotalaria incana, Conyza bonariensis e Ipomoea cairica. Planta Daninha, v. 21, n.1, p.1-9, 2003.

RICHARDSON, R.J.; HATZIOS, K.K.; WILSON, H.P. Absorption, translocation, and metabolism of CGA 362622 in cotton and two weeds. Weed Science, v.51, n.2, p.157-162, 2003.

SANTOS, I.C.; MEIRA, R.M.S.A.; FERREIRA, F.A.; SANTOS, L.D.T.; MIRANDA, G.V. Caracteres anatômicos de duas espécies de trapoeraba e a eficiência do glyphosate. Planta Daninha, v.20, n.1, p.1-8, 2002.

SCHÖNHERR, J.; BUKOVAC, M. J. Penetration of stomata by liquids: dependence on surface tension, wettability, and stomatal morphology. Plant Phisiology, v.49, n.5, p.813-819, 1972. 
SCHREIBER, L.; SCHÖNHERR, J. Analysis of foliar uptake of pesticides in barley leaves: role of epicuticular waxes and compartimentation. Pesticide Science, v.36, n.3, p.213-221, 1992.

SCHULTZ, M.E.; BURNSIDE, O.C. Absorption, translocation, and metabolism of 2, 4 D and glyphosate in hemp dogbane (Apocynum cannabinum). Weed Science, v.28, n.1, p.13-20, 1980.

SHARMA, M.P.; BORN, W.H. Foliar penetration of picloram and 2, 4-D in aspen and balsam poplar. Weed Science, v. 18, n.1, p.57-63, 1970.

TAIZ, L.; ZEIGER, E. Fisiologia vegetal. 3.ed. Porto Alegre: Artmed, 2004. 719 p.

TUFFI SANTOS, L.D.; MEIRA, R.M.S.A.; SANTOS, I.C.; FERREIRA, E.A. Efeito do glyphosate sobre a morfoanatomia das folhas e do caule de Commelina diffusa e $C$. benghalensis. Planta Daninha, v.22, n.1, p.101-108, 2004.

THOMPSON, W.M.; NISSEN, S.J.; MASTERS R.A. Adjuvants effects on imazethapyr, 2, 4 - D and picloram absorption by leafy spurge (Ephorbia esula). Weed Science, v. 44, n.3, p.469-475, 1996.

VICTORIA FILHO, R. Controle de plantas daninhas em pastagens. In: PEIXOTO, A.M.; MOURA, J.C.; PEDROSO, V.P. Pastagens na Amazônia. Piracicaba: FEALQ. 1986. cap.12, p.71-90.

WALL, D.A.; HALL, J.C.; MORRISON, I.N. Uptake, translocation and fate of 2, 4 - D and chlorsulfuron in Silene vulgaris (Moench) Garcke. Weed Research, v.31, n.2, p.81-88, 1991.

WIRTH, W.; STORP, S.; JACOBSEN, W. Mechanisms controlling leaf retention of agricultural spray solutions. Pesticide Science, v.33, n.4, p.411-420, 1991. 
WOLF, T.M.; CALDWELL, B.C.; MCINTYRE, G.I.; HSIAO, A.I. Effect of droplet size and herbicide concentration on absorption and translocation of ${ }^{14} \mathrm{C} 2,4$ - D in oriental mustard (Sisymbrium orientale). Weed Science, v.40, n.4, p.568-575, 1992.

WYRILL, J.B.; BURNSIDE, O.C. Absorption, translocation, and metabolism of 2, 4 D and glyphosate in common milkweed and hemp dogbane. Weed Science, v. 24, n.6, p.557-566, 1976. 